


\title{
Nulidad de reglamentos y actos administrativos por contrariar sentencias
}

\author{
Manuel Rebollo Puig \\ Catedrático de Derecho Administrativo \\ Universidad de Córdoba ${ }^{1}$
}

SUMARIO: I. OBJETO Y PLAN DEL ESTUDIO. II LA NULIDAD PREVISTA EN EL ARTÍCULO 103.4 LJCA. 1. Actuaciones que pueden incurrir en esta causa de nulidad. A) Actuaciones jurídicas de la Administración. B) Actuaciones administrativas en cumplimiento de la sentencia y en ejercicio de cualesquiera potestades. C)Actuaciones de la Administración demandada o de otra. D) Actuaciones posteriores e incluso anteriores a la sentencia. 2. Resoluciones judiciales cuya vulneración puede determinar esta causa de nulidad. A) Sentencias y autos del orden contencioso-administrativo. B) Sentencias de condena pero también merodeclarativas cincluso desestimatorias. C) Sentencias firmes. 3. La vulneración de la sentencia determinante de nulidad. A) El requisito objetivo: contradicción con los pronunciamientos de la sentencia. B) El requisito subjetivo: la finalidad de eludir el cumplimiento de la sentencia. G) ¿Qué sucede si falta alguno de los requisitos?. D) Si se dan los dos requisitos no hay intereses generales que excluyan la nulidad. E) ¿Excesos en la aplicación del artículo 103.4 LJCA? F) Frenos a los excesos. III. LA VÍA DEL ARTíCULO 103.5 LJCA. 1. Naturaleza. A) Un incidente de ejecución que encierra un proceso de cognición. B) Incidente en la ejecución de sentencias de condena y en la de las merodeclarativas. C) Un proceso de cognición sumario. 2. Competencia del juez o tribunal de la ejecución: sus limitaciones. 3.¿Es obligado o al menos posible el recurso administrativo previo? . 4. Plazo. 5.Legitimación. 6. Objeto: actuaciones impugnables y pretensiones. IV. OTROS CAUCES PARA INVOGAR Y ESTIMAR ESTA CAUSA DE NULIDAD. 1. Recurso contencioso-administrativo ordinario y autónomo. A) Naturaleza. B)Supuestos en los que no es posible y en los que sí lo es, ya sea sin la alternativa del

\footnotetext{
Trabajo en el marco del Proyecto de Investigación del Ministerio de Economía y Competitividad PGC2018-093760-B-I00. Grupo de investigación de la Junta de Andalucía SEJ-196.

Recibido: 26/08/2019

Aceptado: 20/09/2019
} 
artículo 103.5 LJCA o ya sea como alternativa a esa vía. C) Agotamiento de la vía administrativa. Plazo. D) Competencia. F) Legitimación. G) Motivos. H) Objeto: actividad impugnable y pretensiones. 2. Contencioso-administrativo especial de protección de los derechos fundamentales. 3. Recursos administrativos. 4. Revisión de oficio. 5. Incidentes de ejecución con otras pretensiones. 6 . No cabe esta causa de nulidad como sustento del incidentes del artículo 108.2 LJCA.

RESUMEN: La Ley de la Jurisdicción Contencioso-Administrativa introdujo como causa de nulidad la contradicción de sentencias para permitir que fuese declarada en ejecución de sentencia. No obstante, esa causa de nulidad, cuyo alcance no es del todo claro, puede declararse por otras vías. Aquí se exponen las circunstancias y los requisitos para que pueda ser declarada. También los cauces procedimentales en que puede ser alegada con éxito, cauces que no son sólo los de la ejecución de sentencias. Todo ello se aborda para que esta causa de nulidad sirva de refuerzo al derecho a la tutela judicial efectiva pero al mismo tiempo tratando de evitar excesos que lleven a la ejecución lo que no es propio de ella.

PALABRAS CLAVE: Jurisdicción contencioso-administrativa. Ejecución de sentencias. Nulidad de actuaciones administrativas.

ABSTRACT. Contentious-Administrative Jurisdiction Law introduced as a cause of nullity the contradiction of sentences. This allows lo declare such a nullity within the judgment enforcement procedure. However, this cause of nullity, whose scope is not entirely clear, can be declared by other means. This paper exposes all the circumstances in which this nullity can be declared and the requirements for that. It also exposes the proceedings in which it can be successfully alleged, including the judgment enforcement procedure. The purpose of this paper is to help this cause of nullity to reinforce the right to the effective judicial protection, trying to avoid, at the same time, possible deviations.

KEYWORDS: Contentious-administrative jurisdiction. Enforcement of judgments. Nullity of administrative decisions.

\section{OBJETO Y PLAN DEL ESTUDIO}

La Ley Reguladora de la Jurisdicción Contencioso-Administrativa de 1998 (en lo sucesivo LJCA) introdujo en su artículo 103.4 una causa de nulidad en estos términos: 
"Serán nulos de pleno derecho los actos y disposiciones contrarios a los pronunciamientos de las sentencias, que se dicten con la finalidad de eludir su cumplimiento."

Aunque incluido en una ley procesal, se trata de un precepto sustantivo al igual que es sustantivo el art. 47 de la Ley de Procedimiento Administrativo Común (en adelante LPAC) $\mathrm{u}$ otros dispersos en diversas leyes materiales (presupuestaria, urbanísticas, de dominio público, etc.) que enuncian diversas causas de nulidad. Ahora bien, es un precepto sustantivo en estrecha relación con el del siguiente apartado, el del artículo 103.5 LJCA, éste sí netamente procesal pues establece un cauce para hacer efectiva esa nulidad:

"El órgano jurisdiccional a quien corresponda la ejecución de la sentencia declarará, a instancia de parte, la nulidad de los actos y disposiciones a que se refiere el apartado anterior, por los trámites previstos en los apartados $2 \mathrm{y}$ 3 del artículo 109, salvo que careciese de competencia para ello conforme a lo dispuesto en esta Ley".

La Exposición de Motivos de la LJCA alude lacónicamente a esta novedad al afirmar que la Ley "previene frente a las ejecuciones aparentes, declarando la nulidad de pleno derecho de los actos contrarios a los pronunciamientos y estableciendo una forma rápida de anularlos...". Así, además de poner de manifiesto la estrecha relación entre el precepto sustantivo (causa de nulidad del art. 103.4) y el procesal (esa "forma rápida" de que habla, que es la del incidente de ejecución del art. 103.5), al aludir a las "ejecuciones aparentes" pone en relación esta novedad legal con la jurisprudencia anterior que ya -con la base que ofrecían los artículos 24.1, 106.1, 117.3 y 118 de la Constitución- había dado notables pasos contra lo que los tribunales llamaban "desobediencia disimulada", "ejecución insincera", "fraudulenta" o, como la misma Exposición de Motivos, "sólo aparente". Por eso, la novedad de los apartados 4 y 5 del art. 103 LJCA es sólo relativa².

2 Incluso se ha afirmado que lo que hace en estos apartados el art. 103 LJCA es sólo "recoger de forma expresa una realidad jurisprudencial". Así HUERTA GARICANO, I. "La ejecución de sentencias en la Ley 29/1998, de la Jurisdicción contencioso-Administrativa, Cuadernos de Derecho fudicial, no 2 (2000), p. 107. De hecho, ya se había mantenido (y se sigue manteniendo, como veremos) que el acto administrativo contrario a una sentencia es nulo, al margen del art. 103.4 LJCA, por constituir vulneración del derecho fundamental a la tutela judicial efectiva en su vertiente de derecho a la ejecución de sentencias. Vid. por todos FONT i LLOVET, T., "Medidas para hacer efectiva la ejecución de las sentencias", en MARTÍN-RETORTILLO BAQUER, L. (Coord.), La protección jurídica del ciudadano. Estudios en homenaje al Profesor Jesús González Pérez, Civitas, Madrid, 1993, p. 1181. Y asimismo se aceptaba que esa nulidad se podía declarar en ejecución. Baste la cita de la STS de 10 de mayo de 2001 (casación 8495/1998; Ar. 3706) que, aunque posterior a la LJCA/98, todavía no la aplica: "Los Tribunales contencioso-administrativos pueden adoptar en fase de ejecución cualquier medida que sea exigida para la ejecución del fallo (...) entre ellas, desde luego, la anulación de actos administrativos dictados para la ejecución o pretendida ejecución del fallo (STC 153/1992, de 19 de octubre)" 
En los ya más de veinte años de vigencia de la LJCA muchas son las resoluciones judiciales que han tenido que enfrentarse a estas dos normas. Una primera lectura de esas resoluciones basta para apreciar que la nulidad del art. 103.4 se ha independizado del cauce del art. 103.5 LJCA. La amplia jurisprudencia sobre esos preceptos ofrece las claves primordiales para su interpretación que se expondrán ordenadamente. Ese será nuestro principal objetivo. Pero también quedan aspectos oscuros que trataremos de acotar y afrontar con el fin de conseguir un conjunto armonioso.

Para acometer estas tareas, se analizará aquí primeramente (epígrafe II) la causa de nulidad del art. 103.4: ¿qué actuaciones pueden incurrir en esta causa de nulidad?; ¿con qué resoluciones ha de producirse la contradicción y elusión de su cumplimiento para que se dé esta nulidad?; ¿qué debe entenderse aquí por "contrarios a los pronunciamientos de las sentencias"?; ¿cuándo habrá finalidad de eludir su cumplimiento? Después (epígrafe III) se abordará el art. 103.5, esto es, el concreto cauce procesal previsto por la LJCA para hacer valer esta causa de nulidad: su naturaleza, sus requisitos, su ámbito material, sus limitaciones... Tras ello (epígrafe IV) se expondrán las otras vías que permiten también invocar con éxito esa misma causa de nulidad, sobre todo la de proceso contencioso-administrativo autónomo.

\section{LA NULIDAD PREVISTA EN EL ARTÍCULO 103.4 LJGA}

\section{Actuaciones que pueden incurrir en esta causa de nulidad}

\section{A) Actuaciones jurídicas de la Administración}

El precepto se refiere a "los actos y disposiciones". Naturalmente actos y disposiciones distintos de los ya anulados por la sentencia. Aunque el art. 103.4 LJCA no lo especifique, han de provenir de la Administración. Quedan, pues, extramuros del art. 103.4 (y, por supuesto, del art. 103.5) LJCA las leyes, incluso cuando contengan decisiones singulares de convalidación o cualesquiera otras que impidan la ejecución de sentencias ${ }^{3}$. Y quedan dentro los actos administrativos y los reglamentos (incluidos los planes aprobados por la Administración, que, en el caso de los urbanísticos, han sido con notable frecuencia los declarados nulos por esta causa). Deben considerarse

3 GALÁN GALÁN, A., "Los poderes del juez en la ejecución de las sentencias: reacción frente a actos de la Administración o del legislador que tengan como fin eludir su cumplimiento", en SÁNCHEZ LAMELA, A. La ejecución de las sentencias contencioso-administrativas, Aranzadi, 2006, pp. 136-137. También las leyes, por supuesto, pueden contradecir sentencias con la finalidad de impedir su cumplimiento y eventualmente puede que ello acarree su nulidad por vulneración del derecho a la tutela judicial efectiva (por ejemplo, SSTS 312/2006 y 50/2015). Pero eso tiene otro régimen material y procesal, no el del art. 103.4 y 5 LJCA. 
comprendidos igualmente los convenios y contratos suscritos por la Administración: lo contrario dejaría al margen de esta causa de nulidad un frente de posibles incumplimientos sin ningún fundamento sólido. En suma, todos los tipos de actuaciones jurídicas de la Administración pueden incurrir en esta causa nulidad. Por el contrario, las actuaciones materiales y las simples omisiones quedan fuera ${ }^{4}$ : respecto a ellas no tiene sentido predicar la nulidad que sólo es posible para actos jurídicos ${ }^{5}$; además, para combatir esas actuaciones materiales u omisiones contrarias a la sentencia la LJCA establece otro remedio en su art. 108.2.

B) Actuaciones administrativas en cumplimiento de la sentencia y actuaciones en ejercicio de cualesquiera potestades

Las actuaciones jurídicas de la Administración que pueden incurrir en esta causa de nulidad son de dos géneros.

Por un lado, las que se produzcan formal y directamente para cumplir el fallo. Aquí entran los actos de la Administración debidos para el cumplimiento de la sentencia (aunque precisamente se les impute que más bien la contradicen); es decir, los producidos para la equívocamente llamada "ejecución voluntaria de la sentencia". Así, por ejemplo, si la sentencia declara el derecho de una persona a ser nombrada funcionaria y, por ende, condena a la Administración demandada a reconocerlo, el acto de nombramiento que dicte entra en esta categoría. Son actos de la Administración que, según se suele explicar, no son propiamente actos administrativos sino que tienen otra naturaleza ${ }^{6}$.

4 En contra, CLAVERO ARÉVALO, M., "Actuaciones administrativas contrarias a los pronunciamientos de las sentencias", en La justicia administrativa. Libro homenaje al Prof. Dr. D. Rafael Entrena Cuesta, Atelier, Barcelona, 2003, p. 928; y GIMENO SENDRA, V., Comentarios a la nueva Ley de la furisdicción Contencioso-Administrativa, Centro de Estudios Ramón Areces, Madrid, 1999, p. 731.

5 Así, XIOL RÍOS, J. A., "Artículo 103”, en ESPÍN TEMPLADO, E. (Coord.), Comentarios a la Ley Reguladora de la furisdicción Contencioso-Administrativa, Tirant lo Blanch, Valencia, 2016, p. 723.

6 La doctrina ha insistido en ello. Así, FONT i LLOVET, T., La ejecución de las sentencias contencioso-administrativas. Aspectos constitucionales, Civitas, Madrid, 1985, y, del mismo autor, "Justicia administrativa y ejecución de sentencias", en MONTORO CHINER, M. J. (Coord.), La justicia administrativa. Libro homenaje al Prof. Dr. D. Rafael Entrena Cuesta, Atelier, Barcelona, 2003, pp. 822 y 826, donde afirma que "ejecutar o cumplir una sentencia ya no es administrar". Sobre todo J. M. BAÑO LEÓN, "La eficacia de las sentencias contra la Administración o la claudicación del Estado de Derecho", REDA, núm. 177 (2016), pp. 87, 92 y 96, ha recalcado que en estos supuestos de actuación de la Administración condenada por sentencia no hay "un acto administrativo dictado al amparo de una competencia específica"; "... no es (...) un acto administrativo en sentido propio..."; “... el acto de la Administración dictado para materializar la sentencia no es un acto administrativo emanado de la simple voluntad de la Administración...". Y antes ya TORNOS MAS, J., "Artículo 103.1, 2 y 3", REDA, no 100 (1998), p. 717, explicaba que "en esta ejecución no actúa como Administración, ejerciendo potestades propias y actuando objetivamente al servicio de intereses generales, sino que actuará como parte vencida en juicio (...) La posición de la Administración ha cambiado de modo sustancial...". Más radicalmente se pronuncia respecto a las actuaciones de la Administración 
Por otro lado también están incluidos los reglamentos, actos y convenios administrativos producidos al margen del cumplimiento de la sentencia en ejercicio ordinario de las potestades de la Administración: si la sentencia declaró nulo un reglamento, la aprobación de otro reglamento no será cumplimiento de aquella sentencia, sino simple ejercicio de la potestad reglamentaria que la Administración tiene completamente al margen de la sentencia anulatoria anterior, pero también podrá ser nulo en virtud del art. 103.4 LJGA7 ; lo mismo si la sentencia, por ejemplo, anuló una concesión: el otorgamiento de una nueva concesión, que no imponía aquella sentencia, no será cumplimiento de la sentencia pero sí que puede reunir los requisitos de esta causa de nulidad del art. 103.4. Justamente el que este otro tipo de actuaciones puedan incurrir en esta causa de nulidad y declararse en ejecución de sentencie fue la novedad más relevante de la $\mathrm{LJCA}^{8}$.

Ambos géneros de actuaciones pueden ser nulas ex art. 103.4 LJCA. Pero, incluso así, la distinción es crucial pues, como luego se verá, tienen en parte régimen procesal diferente.

como mera colaboradora en la ejecución de sentencias correspondientes a procesos en los que no ha sido parte (p. 719). Pero no es esto último lo que ahora nos incumbe. También ORTEGA ÁLVAREZ, L., "La ejecución de sentencias", en LEGUINA VILLA, J. y SÁNCHEZ MORÓN, M. (Dirs.), Comentario a la Ley de la furisdicción Contencioso-Administrativa, Lex Nova, Valladolid, $2^{\mathrm{a}}$ ed., 2001, pp. 504-505, apunta esas ideas. En igual dirección HUERTA GARICANO, I. (2000: 106), dice: “... los actos dictados por la Administración en ejecución de sentencias firmes no son actos de ésta sujetos a Derecho Administrativo y susceptibles de impugnación autónoma en vía jurisdiccional, sino que son diligencias de ejecución de lo resuelto en sentencia que se revisan (...) dentro del mismo proceso...".

7 Exactamente igual debe decirse ante las anulaciones judiciales de planes de urbanismo ante lo que la aprobación de uno nuevo no es ejecución de la sentencia anulatoria. Alguna vez lo ha explicitado el TS: "Ciertamente, anulado un plan urbanístico, la Administración puede abandonar todo propósito ulterior de acometer la ordenación pretendida. Forzoso resulta admitir la renuncia como una opción..." (sentencia de 5 de julio de 2012, casación 2922/2010; Ar. 7735). No se trata propiamente de una renuncia, pero la afirmación sirve para patentizar que, como regla general, salvo que de la concreta sentencia se deduzca otra cosa, la Administración puede perfectamente dejar en vigor el plan resurgido sin emprender ahora su revisión. Como dice BAÑO LEÓN, J. M., "La retroacción de actuaciones ¿denegación de justicia o garantía del justiciable?", en GARCÍA DE ENTERRÍA, E., y ALONSO GARCÍA, R. (Coords.), $A d-$ ministración y justicia. Un análisis jurisprudencial. Liber amicorum Tomás-Ramón Fernández, Civitas, 2012, I, p. 598, "en procedimientos normativos y de planificación", tras la anulación por sentencia del reglamento o plan, "retomar o no el procedimiento entra en la discrecionalidad de la Administración"; por tanto, si decide retomarlo, eso no es ejecución de la sentencia.

$8 \quad$ Lo explica XIOL RÍOS, J. A. (2016: 721): “... la relevancia de este precepto radica en que se refiere no sólo a los actos que la Administración dicte directamente para ejecutar la sentencia -sobre los cuales no existía ya duda (...) de que podían ser anulados durante el procedimiento de ejecución si no se ajustaban al fallo- sino también de los actos (...) que, ajenos en principio al proceso de ejecución, obstaculizan la efectividad de la sentencia...". Antes había detectado que esto era "lo realmente novedoso", GALÁN GALÁN, A. (2006: 138). 


\section{C) Actuaciones de la Administración demandada o de otra}

Lo normal es que la actuación nula ex art. 103.4 LJCA sea de la misma Administración vencida en el juicio originario. Ello con independencia de que pueda provenir de un órgano de esa Administración diferente del que produjo la actuación objeto de aquél ${ }^{9}$. Pero ¿podría ser una actuación de Administración distinta? La literalidad del art. 103.4 LJCA no lo excluye y, según creo, no hay razones de fondo para cerrar completamente esa posibilidad pese a que los tribunales se muestran reticentes ${ }^{10}$. Sobre todo, aunque no exclusivamente, hay que aceptar esta posibilidad cuando se trate de la Administración matriz y uno de sus entes instrumentales (por ejemplo, el demandado y vencido fue un organismo autónomo local y quien produce el acto o reglamento contrario a la sentencia y con la finalidad de eludirla es el Ayuntamiento; o viceversa). Aunque se aceptara la nulidad ex art. 103.4 LJCA de actuaciones provenientes de una Administración distinta de la demandada en el proceso originario, cuestión diversa es si tal nulidad podría declararse en el incidente del art. 103.5 LJCA. Lo abordaremos después.

\section{D) Actuaciones posteriores e incluso anteriores a la sentencia}

Cabría pensar en principio que esta causa de nulidad sólo puede aquejar a actuaciones jurídicas posteriores a la sentencia. Pero, aunque el TS acogió inicial-

9 De hecho, eso es lo que explica que puedan no coincidir los tribunales competentes (art. 103.5 in fine), como observó CLAVERO ARÉVALO, M. (2003:928).

10 Por ejemplo, dice la STS 1774/2016, de 14 julio (casación núm. 3620/2015. Ar. 3799) que, "abundando en el requisito subjetivo, parece requerirse, en principio, que tales actos sean dictados por aquellos que están directamente obligados al cumplimiento de la sentencia, salvo supuestos en los que la conexión del acto dictado y el contenido del fallo cuya ejecución se pretende resulte incontrovertible". La STS de 23 de diciembre de 2010 (casación 2970/2006; Ar. 1033 de 2011) declara: "El hecho de que el nuevo planeamiento sea aprobado por Administración distinta de la que dictó el acto revisado en la sentencia, permite considerar la ausencia de desviación de poder, debido a la dificultad de acreditar la connivencia en el procedimiento compartido de Revisión del PGOU entre ambas Administraciones". La STS de 18 de diciembre de 2014 (casación 2847/2012; Ar. 6823) lo reitera. Estas sentencias no parecen excluir totalmente la posibilidad de que un acto de otra Administración sea nulo ex art. 103.4 LJCA. Además, el argumento que utilizan no es concluyente: sólo que si se trata de otra Administración es más difícil imaginar que se dé el requisito subjetivo de la finalidad de eludir la sentencia; pero podría existir esa "connivencia" entre Administraciones de que hablan las sentencias. Por eso no cabe descartar que tengan razón quienes han aceptado esta posibilidad: GALÁN GALÁN, A. (2006:138); y GEIS i CARRERAS, G., La ejecución de las sentencias urbanísticas, Atelier, $2^{\mathrm{a}}$ ed., 2013, p. 162. 
mente esta tesis ${ }^{11}$, después, como ya había preconizado algún autor ${ }^{12}$, ha terminado por aceptar que esta causa de nulidad también puede afectar a actos y reglamentos anteriores a la sentencia. Ello cuando, vaticinando una sentencia adversa, se dictaron preventivamente con la finalidad de eludirla ${ }^{13}$. En estos casos, la nulidad del art. 103.4 LJCA no podrá invocarse hasta que se produzca la sentencia que pretende contradecirse y eludirse (rectius: hasta que la sentencia alcance firmeza, como luego se dirá); pero los efectos de la nulidad se retrotraerán al momento mismo en que se dictó el acto o reglamento nulo ex art. 103.4 $\mathrm{LJCA}^{14}$. Plantean estos actos anteriores

11 SSTS de 3 de marzo de 1999 (casación 323/1994), de 29 de octubre de 2001 (casación 2543/1996), ATS de 5 de febrero de 2001. No obstante pueden detectarse algunas desviaciones; por ejemplo en STS de 19 de mayo de 1999 (Ar. 3639). Vid. GONZÁLEZ PÉREZ, J., Comentarios a la Ley de la Ley de la Jurisdicción Contencioso-Administrativa, Civitas, $3^{\text {a }}$ ed., 1998, II, p. 1785, y CLAVERO ARÉVALO, M. (2003: 928).

12 ORTEGA ÁLVAREZ, L. (2001: 509): “... dada la literalidad del art. 103.4, si existe prueba de que $(\ldots)$ se dictaron en previsión de una sentencia desfavorable (...) cabría la declaración de nulidad por el trámite de incidentes dado el sentido teleológico del precepto". Véase también EZQUERRA HUERVA, A., "La ejecución de sentencias", en EZQUERRA HUERVA, A. y OLIVÁN DEL CACHO, J. (Dirs.), Estudio de la Ley de la furisdicción Contencioso-Administrativa, Tirant lo Blanch, 2014, pp. 975-976; GALÁN GALÁN, A. (2006: 139); AGOUÉS MENDIZÁBAL, C., "La modulación de los efectos de la invalidez de los reglamentos", en El alcance de la invalidez de la actuación administrativa: Actas del XII Congreso de la Asociación Española de Profesores de Derecho Administrativo, 2017, p. 401; SUAY RINCÓN, J. "La «afectación" de la anulación de los Planes de Urbanismo a sus actos de ejecución: la perspectiva de la Ley Jurisdiccional", Revista de Derecho Urbanístico y Medio Ambiente, núm. 324 (2018), p. 45.

13 Lo explica la STS de 19 de junio de 2013 (casación 2713/2012): "No es correcto el criterio (según el cual) el artículo 103.4 LJCA está previsto [únicamente] para los supuestos de que, previa existencia de un pronunciamiento jurisdiccional, se dicten con posterioridad actuaciones o disposiciones que inciden de forma directa en la ejecución de la previa sentencia. No obstante ser esa situación la más frecuente, puede ocurrir igualmente que, vaticinando el resultado adverso del proceso todavía no resuelto, se realicen actuaciones precisamente con el designio fraudulento de evitar el cumplimiento". Buen ejemplo es la STS de 19 de febrero de 2013 (casación 5525/2010; Ar. 3195): anuló un PERI que salvaba una edificación cuya licencia se veía en peligro aunque se aprobó antes de la sentencia anulatoria de la licencia; ello porque la Administración era "perfectamente conocedora de la pendencia de ese proceso judicial" y con la aprobación del plan buscaba "sólo anticiparse a una inminente declaración judicial de nulidad" y así "frustrar una sentencia estimatoria con la que ya contaba de antemano": pretendía "anticipar la respuesta a una declaración de nulidad que vislumbraba ineludible". En la misma dirección, véanse, entre otras, SSTS de 18 de diciembre de 2014 (casación 2847/2012; Ar. 6823), de 12 de marzo de 2015 (casación 1881/2014; Ar. 3626), STS 1285/2016 de 2 junio (Ar. 3123) y 1997/2016, de 6 de septiembre (casación 3365/2014; Ar. 5776).

14 Por eso no puede decirse exactamente que estemos en un supuesto de invalidez sobrevenida. Sigo en este punto a CANO CAMPOS, T., La invalidez sobrevenida de los actos administrativos, Civitas, Madrid, 2004, pp. 224 a 229, que acoge un concepto restrictivo. Explica que no basta para que haya invalidez sobrevenida que el vicio surja después del acto sino que es necesario que también los efectos de la invalidez sean posteriores al acto y no se retrotraigan al momento originario en que se dictó; es decir, que para que haya invalidez sobrevenida tiene que tratarse de un supuesto en que se acepte que el acto ha producido durante cierto tiempo efectos lícitos que no se van a destruir. Y esto no se daría en el caso aquí analizado pues el acto o reglamento dictado antes de la sentencia pero vaticinando su resultado adverso y tratando de eludirlo 
a la sentencia nulos conforme al art. 103.4 LJCA un problema especial en cuanto al plazo para recurrirlos que abordaremos en el momento oportuno ${ }^{15}$.

\section{Resoluciones judiciales cuya vulneración puede determinar esta causa de nulidad}

\section{A) Sentencias y autos del orden contencioso-administrativo}

No dice el art. 103.4 LJCA que la sentencia vulnerada haya ser del orden contencioso-administrativo. Pero, al incluirse en la LJCA y precisamente en el capítulo dedicado a la ejecución de las sentencias de esta jurisdicción, la conclusión se impone: quedan fuera las resoluciones de cualquier otra jurisdicción o del $\mathrm{TC}^{16}$; y, por supuesto, las de la propia Administración, aunque resuelvan recursos y contengan declaraciones materialmente iguales a las de las sentencias ${ }^{17}$.

tendrá una nulidad cuyos efectos se retrotraerán al momento en que se dictaron. Estaremos, pues, ante una nulidad originaria, aunque con la singularidad de que no podrá invocarse desde el primer momento sino sólo cuando se dicte la sentencia que se quería burlar. Acaso pueda decirse que hay una ilegalidad sobrevenida pero no propiamente una invalidez sobrevenida.

15 Completamente distinto de lo aquí analizado es que haya otros reglamentos y actos también anteriores a la sentencia anulatoria que queden afectados por ésta y cuya invalidez pueda declararse al margen del art. 103.4 LJCA. Por ejemplo, todos los planes de desarrollo de un plan anulado y todos los actos que lo aplicaron (salvo que hayan devenido firmes; art. 73 LJCA). Otra cosa es si la nulidad de los planes de desarrollo aprobados antes de la sentencia que anuló al plan desarrollado puede declararse siempre en ejecución de ésta o si solo será así si están afectados por el vicio del art. 103.4 LJCA. Esto último es lo acogido por la STS 1997/2016, de 6 de septiembre (casación 3365/2014; Ar. 5776), en ejecución de la sentencia de un plan sólo se podría declarar la nulidad de planes de desarrollo del anulado anteriores a la sentencia si se dictaron "con ánimo defraudatorio (...) por responder a una finalidad espuria". En esta línea SUAY RINCÓN,J., (2018: 54-58, passim). En contra, STS de 19 de junio de 2013 (casación 2713/2012, Ar. 5629) que, ante la sentencia que anuló planeamiento general, declaró en ejecución de aquélla la nulidad del plan de desarrollo aunque no se aprobó "con el fin espurio de eludir su cumplimiento".

16 La solución sería diferente si esta causa de nulidad se hubiera incluido en el art. 47 LPAC o en la LOPJ. Quizá habría sido preferible porque las mismas razones que han llevado a la LJCA a establecer esta causa de nulidad (reforzar el derecho a la tutela judicial efectiva) podrían justificar que también se estableciera la nulidad para las actuaciones de las Administraciones que vulnerasen de igual forma sentencias de los órdenes civil, penal, social, militar y contable o, ya en otro plano, de la jurisdicción constitucional.

Distinto es que otras leyes establezcan causas de invalidez similares como hace, tras la reforma de 2015, el art. 92.1.2 ${ }^{\circ}$ LOTC para cuya aplicación, si acaso, podría jugar supletoriamente la LJCA (art. 80.2 ${ }^{\circ}$ LOTG). Vid. FERNÁNDEZ FARRERES, G., "Las nuevas facultades del Tribunal Constitucional para asegurar el cumplimiento de sus resoluciones", Revista Española de Derecho Constitucional, nº 112 (2018), p. 40.

17 Si la Administración dicta actos contrarios a sus resoluciones de recursos (aunque sean de algunos de sus llamados Tribunales, como los económico-administrativos o los establecidos en materia de contratos) o de revisiones de oficio lo que surgirá será otro problema, el de la revocación de los actos administrativos favorables, que nada tiene que ver con el derecho a la tutela judicial efectiva ni con el art. 103 LJCA. 
Dentro del orden contencioso-administrativo, pese a que el art. 103.4 LJCA habla precisamente de sentencias, igual causa de nulidad concurrirá cuando la actuación jurídica de la Administración contradiga autos de esa jurisdicción; por ejemplo, los que adopten medidas cautelares ${ }^{18} \mathrm{o}$, rizando el rizo, los que resuelvan incidentes de ejecución. También hay que aceptar la aplicación del art. 103.4 frente a los actos o disposiciones contrarios a lo acordado entre las partes conforme al art. $77 \mathrm{LJCA}^{19}$. Por contra, no es posible aplicar el art. 103.4 en los supuestos de allanamiento (art. 75) y de reconocimiento en vía administrativa de las pretensiones del demandante $(\operatorname{art.} 76)^{20}$.

\section{B) Sentencias de condena; pero también merodeclarativas ¿incluso desestimatorias?}

Desde luego, esta causa de nulidad procede ante la vulneración de sentencias de condena a la Administración. Pero no sólo ante ellas: puede tratarse de sentencias meramente declarativas (las que declaran una nulidad de pleno derecho) o constitutivas (las que anulan lo anulable). No dice el art. 103.4 que se refiera exclusivamente a sentencias de condena y, en realidad, tampoco de su función y sentido general cabe deducir tal limitación. Es más, en gran parte de los casos en los que se ha aplicado el art. 103.4 LJCA la sentencia de partida era meramente declarativa o constitutiva, no de condena. Es cierto que ante ese género de sentencias nada concreto y positivo debe hacer o dar la Administración para su cumplimiento. Pero sí hay que acatarlas, no actuar en contra de sus pronunciamientos. Y es este deber negativo el que aquí encuentra respaldo.

18 Ya apuntó FERNÁNDEZ, T. R., "Algunas reflexiones sobre las formas indirectas de incumplimiento por la Administración de las sentencias de los tribunales de la jurisdicción contencioso-administrativa", RAP, núm. 73 (1974), pp. 175 a 177, que los mismos problemas que surgen ante los actos que reproducen al anulado por sentencia se dan respecto a los actos que reiteran al suspendido por auto; y no hay razón para que la respuesta sea distinta. Véase la sentencia del Tribunal de Conflictos de Jurisdicción de 17 de junio de 2008; Ar. 1973 de 2010) que precisamente versaba sobre la aplicación del art. 103.4 LJCA ante un acto administrativo contrario al auto de medidas cautelares.

19 En ese supuesto no se tratará de actuaciones contrarias a una decisión judicial porque - como explica HUERGO LORA, A., La resolución extrajudicial de conflictos en Derecho Administrativo, Publicaciones del Real Colegio de España, Bolonia, 2000, p. 146- la aprobación por el juez de la transacción no convierte a lo pactado en el contenido de una decisión judicial. Pero, pese a ello, la aplicación del art. 103.4 LJCA deriva del art. 113 LJCA. Véase por todos PÉREZ MORENO, A., "La conciliación judicial", Fusticia Administrati$v a, \mathrm{n}^{\circ}$ extraordinario dedicado a la Ley de la Jurisdicción Contencioso-Administrativa (1999), pp. 113 y 119.

$20 \mathrm{El}$ art. 74.7 LJCA conduce a negar en esos casos la aplicación del art. 103.4 y 5 puesto que lo que prevé para el supuesto de un "nuevo acto total o parcialmente revocatorio" es que continúe el proceso contencioso-administrativo aunque "extendiéndose al acto revocatorio". La exclusión ahí del art. 103.4 y 5 es, además, completamente lógica como lo es en todo caso en que la Administración haya dado satisfacción a las pretensiones del administrado (por ejemplo, al resolver un recurso administrativo) y después dicte actos contrarios al anterior: eso remite, como ya se ha dicho en una nota anterior, a otro problema (revocación de actos administrativos favorables) que nada tiene que ver con la eficacia de las resoluciones judiciales ni con la tutela judicial efectiva. 
Más todavía y hasta más sorprendente: aunque las sentencias desestimatorias (que, por tanto, confirman el acto recurrido) no deben ser objeto de ejecución judi$\mathrm{cial}^{21}$, acaso sí que podrían fundamentar la nulidad que estudiamos ${ }^{22}$; en concreto, tal vez podría imputarse esta nulidad a una revisión de oficio (art. 106 LPAC) del acto confirmado por sentencia ${ }^{23}$.

21 Lo que en tales casos procede ejecutar es el acto administrativo confirmado, no la sentencia confirmatoria; y naturalmente aquello se hace siguiendo las reglas del procedimiento administrativo, no las procesales. Véase GONZÁLEZ PÉREZ, J. (1998: 996-997); HUERTA GARICANO, I. (2000: 104); y TOLOSA TRIBIÑO, C., "El incidente de ejecución de sentencias: aspectos procesales", en SÁNCHEZ LAMELA, A. (Coord.), La ejecución de sentencias contencioso-administrativas, Aranzadi, 2006, pp. 175 a 177. Hay, no obstante, cierta confusión. Ya la alimentaba la LJCA de 1956 cuyo art. 105.5 hablaba de ejecución de sentencias confirmatorias de actos o disposiciones de la Administración. Aunque ni restos de ello hay en la vigente LJCA, avivaron la confusión las SSTC 160/1991, 76/1992 y 174/1993 para los casos en que la ejecución del acto administrativo confirmado exigiera entrada en domicilios: para tal caso el TC eximió de la autorización judicial porque ya había mediado sentencia; pero una cosa es que se exima de autorización judicial para entrar en domicilios en virtud de actos administrativos confirmados judicialmente (como sucede cuando el registro domiciliario lo acuerdan directamente los jueces) y otra que en tales casos se esté ejecutando la sentencia confirmatoria: no es así; se ejecuta el acto administrativo confirmado.

22 Al menos, así lo entendió la STS de 23 de diciembre de 2010 (casación 2970/2006; Ar. 1033 de 2011). Lo que hizo la sentencia de cuya supuesta ejecución se trataba fue desestimar el recurso y, por tanto, confirmar un acto administrativo por el que se ordenaba demoler una construcción. Luego el Ayuntamiento revisó el PGOU con lo que aquella obra se convertía en legal y devenía imposible ejecutar la decisión administrativa de demolición. Pero el TS aceptó aplicar frente a esa Revisión del PGOU el art. 103.4 LJCA. Creo que se equivocó. Lo que protegió no fue propiamente hablando lo decidido por una sentencia sino lo decidido por la Administración aunque confirmado por sentencia; aquí poco tenía que ver el derecho a la tutela judicial efectiva.

23 Dice el art. 213.3 LGT: "Cuando hayan sido confirmados por sentencia judicial firme, no serán revisables en ningún caso los actos de aplicación de los tributos y de imposición de sanciones...”. Igualmente art. 14.1.b) TRLHL. No hay en la LPAC regla similar. Pero el TS, con distintos argumentos (la cosa juzgada; o la literalidad el art. 102.1 Ley 30/1992, como ahora el art. 106.1 LPAC, que se refieren a actos "que no hayan sido recurridos en plazo") niega esa posibilidad de revisión de oficio del acto judicialmente confirmado (SSTS de 28 de enero de 2014, casación 553/2012, Ar. 683; de 13 de febrero de 2015, casación 537/2013, Ar. 1052; y de 25 de noviembre de 2015, casación 269/2014, Ar. 5411). Con todo, en algún supuesto excepcional se ha admitido la revisión de oficio de actos confirmados en sentencia (así en la STS $57 / 2017$, de 18 de enero, que reiteradamente insiste en que se basa en las características singulares del caso; casación 1469/2015; Ar. 1198). Véanse BUENO ARMIJO, A., "La revisión de oficio", en GOSÁLBEZ PEQUEÑO, H. (Dir.), La nueva Ley del Procedimiento Administrativo Común, Wolters Kluwer, 2016, p. 449; SUAY RINCÓN, J., "La caracterización jurídica de la potestad de revisión de oficio", en SORIANO GARCÍA, J. E. (Dir.), Por el Derecho y la libertad. Libro homenaje al Profesor Fuan Alfonso Santamaría Pastor, Iustel, 2014, II, p. 1385; y REBOLLO PUIG, M., "Artículos 72 y 73”, REDA, núm. 100 (1998), p. 525. Según creo, la revisión de oficio del acto confirmado debe quedar proscrita sólo cuando se oponga a lo ya juzgado y, por tanto, sería lícita si se basara en vicios distintos de los analizados en la sentencia o si se tratara de sentencia sin cosa juzgada (como las desestimatorias de recursos directos contra reglamentos; art. 26.2 LJCA). Dejando estos aspectos al margen, lo que apuntamos en el texto es que, suponiendo que en un determinado caso realmente la revisión de oficio vaya contra lo ya juzgado en la sentencia confirmatoria, tal revisión podría estar incursa en la causa de nulidad del art. 103.4 LJCA. Y si esto se acepta es que, en efecto, también las sentencias desestimatorias sustentan esta causa de nulidad y hasta la posibilidad de declararla en ejecución 
Por otra parte, aunque lo más normal es que sean sentencias dictadas en recursos contra actos o reglamentos, nada impide que las sentencias relativas a inactividad de la Administración o a la vía de hecho den lugar a esta nulidad. Tampoco importa que hayan recaído en un procedimiento ordinario o en alguno de los especiales.

\section{C) Sentencias firmes}

Dijimos antes que la nulidad del art. 103.4 LJCA puede aquejar a actos anteriores a la sentencia. Si es así, con mayor razón pueden incurrir en esa nulidad los actos posteriores a la sentencia pero anteriores a su firmeza. Ahora bien, sólo desde el momento en que la sentencia pretendidamente contradicha y eludida devenga firme cabrá invocar con éxito esta causa de nulidad ${ }^{24}$. Ni siquiera la ejecución provisional de la sentencia determinará por sí misma esta nulidad. Aceptar lo contrario, teniendo en cuenta que la sentencia vulnerada puede ser revocada, sería tanto como admitir una nulidad que primero aparece y luego desaparece. Y consecuentemente llevaría a entender que la resolución judicial que anulara un acto de acuerdo con el art. 103.4 LJCA podría perder después su eficacia cuando la sentencia vulnerada fuese revocada. Nada de eso es asumible.

\section{Requisitos de la vulneración de la sentencia}

El art. 103.4 LJCA proclama la nulidad de los actos y disposiciones "contrarios a los pronunciamientos de la sentencia, que se dicten con la finalidad de eludir su cumplimiento". De ahí se deducen, como lo expresa la jurisprudencia, dos requisitos: uno objetivo, la contradicción material con la sentencia; y otro subjetivo, la finalidad de eludir su cumplimiento.

de la sentencia por la vía del art. 103.5 LJCA. Es esto lo que obiter dicta admiten las SSTS de 20 de octubre de 2008 (casación 5719/2006; Ar. 5750) y de 24 de mayo de 2011 (casación 3338/2010; Ar. 4687). Dicen que no cabe afirmar "de forma categórica (...) que las sentencias desestimatorias no son ejecutables": "el alcance eminentemente declarativo del pronunciamiento desestimatorio del recurso no impide que puedan suscitarse incidentes de ejecución. Piénsese, por ejemplo, que la Administración vencedora en el litigio inicia luego los trámites para la revocación de ese mismo acto, o para su revisión de oficio, o sencillamente, desiste de ejecutar la decisión cuya validez ha sido respaldada en vía jurisdiccional; y es entonces un tercero (...) quien insta ante el Tribunal el efectivo cumplimiento de lo decidido en la sentencia...". Buena parte de esta afirmación es errónea. Desde luego lo es en cuanto a la revocación o a la decisión de no ejecutar del acto confirmado. Nada de eso entra en el art. 103.4 LJCA. Entre otras cosas porque nada de eso es contrario a la sentencia confirmatoria. Pero sí puede tener parte de razón en cuanto a la revisión de oficio del acto confirmado si el vicio invocado para tal revisión es el mismo que descartó la sentencia confirmatoria.

24 En contra CLAVERO ARÉVALO, M., (2003: 932), no exige que la sentencia sea firme. 


\section{A) El requisito objetivo: contradicción con los pronunciamientos de la sentencia}

La contradicción con "los pronunciamientos de la sentencia" ha de ser con su fallo ${ }^{25}$. Ahora bien, más allá de las palabras pronunciadas en el fallo, inexorablemente hay que atender también a la ratio decidendi de la sentencia. Sin ella no se puede saber siquiera lo que realmente se ha fallado. Pero no se trata de dar valor autónomo a la ratio decidendi ${ }^{26}$ pues ello sería tanto como incluir en el art. 103.4 la vulneración de la doctrina de los tribunales, lo que daría una amplitud absurda a esta causa de nulidad y, sumado al art. 103.5 LJCA, llevaría a la ejecución de las sentencias asuntos ajenos a lo juzgado ${ }^{27}$. Lo que hay que proclamar es que se da este requisito objetivo cuando hay contradicción con el fallo pero acotado éste en función de la ratio decidendi.

La ratio decidendi incluye la motivación jurídica fundamental ${ }^{28}$ y los hechos determinantes tomados en consideración, para cuyo acotamiento ocasionalmente hay que atender a la totalidad del debate procesal, empezando por la demanda y su causa petend $i^{29}$.

25 CLAVERO ARÉVALO, M. (2003: 931). Si admitimos, como aquí se ha hecho, que también puede haber esta nulidad por vulnerar autos, la contradicción deberá referirse a su "resuelve".

26 GALÁN GALÁN, A. (2006: 140-141): “... la declaración de nulidad del art. 103.4 LJCA se extiende no sólo a los actos y disposiciones que sean contrarios al fallo, sino también a los fundamentos jurídicos, siempre que constituyan ratio decidendi de la sentencia". Más exacto es decir que se extiende solo al fallo aunque éste haya de interpretarse atendiendo a la ratio decidendi.

27 Es importante destacarlo y excluir del art. 103.4 ciertos casos en los que la contradicción con la ratio decidendi es flagrante y hasta sangrante. Piénsese en una sentencia que, por ejemplo, anule una liquidación del IBI por considerar que se trata de un bien no sometido a ese impuesto o en otra que anule una sanción por entender que determinada conducta no es típica. Si después la Administración en el ejercicio siguiente vuelve a liquidar el IBI o si vuelve a sancionar una conducta igual, incluso contra el mismo sujeto, estará actuando ilegalmente. Entre otras cosas porque conforme a la ratio decidendi de la sentencia anterior ya debe aceptarse que ese bien está exento del IBI o que tal género de conducta no es típica. Acaso incluso pueda decirse que la autoridad que practique la nueva liquidación o imponga esa nueva sanción estará prevaricando. De acuerdo. Todo lo que se diga sobre la ilegalidad de esa nueva liquidación o sanción será poco. Pero, aceptado eso, lo que no cabe decir es que esa nueva liquidación relativa a otro año o esa nueva sanción impuesta por otros hechos (aunque iguales a los anteriores) incurre en la contradicción con la sentencia anterior de que habla el art. 103.4 LJCA: no es contraria a lo fallado (aunque sí que sea contrario a la ratio decidendi). La idea queda bien reflejada en la STS de 20 de octubre de 2011 (casación 522/2009; Ar. 1317 de 2012). Distingue entre actuaciones contrarias al fallo y aquellas otras que no son contrarias al fallo sino sólo a la fundamentación de la sentencia. En este segundo caso no procede ninguna modalidad de ejecución sino a lo sumo interponer un nuevo recurso invocando esa fundamentación: “... independientemente de que la fundamentación conducente a ese fallo, que no el fallo mismo, pudiera servir de base (...) a pretensiones similares (...) para formular recursos diferenciados...”.

28 No, por supuesto, a lo que solo aparezca como obiter dicta. A este respecto es rotunda la STS 127/2019, de 6 de febrero (Ar. 410): acepta que se tenga en cuenta la ratio decidendi de la sentencia de casación pero no los razonamientos obiter dicta "sin influencia alguna en el fallo".

29 Encuentra ello apoyo en la jurisprudencia constitucional. Por ejemplo, explica la STC 50/2015, de 5 de marzo: “... fallo, fundamentos de las partes, hechos debatidos y argumentos planteados en defensa de las posturas encontradas son manifestaciones de «una línea secuencial que une las alegaciones y preten- 
Por lo que concierne a la motivación jurídica, si de una sentencia anulatoria se trata habrá que atender al concreto vicio que ha llevado a la anulación judicial. De modo que, incluso aunque el nuevo acto o reglamento fuese de contenido material igual al anulado, no se dará el requisito objetivo -y, por tanto, no será de aplicación el art. 103.4 LJCA- si no se incurre en el mismo vicio que determinó su anulación. Así, si los vicios por los que se anuló un acto o reglamento (o plan) fuesen formales nada obstará a que, tras la tramitación pertinente, lo decidido en el nuevo acto, reglamento (o plan) sea igual a lo establecido en el anulado por sentencia ${ }^{30}$; si la nulidad se hubiera decretado por falta o insuficiencia de motivación, no será ilícito volver a aprobar el mismo acto, reglamento (o plan) ahora con una motivación adecuada ${ }^{31}$; si la nulidad se hubiera acordado por vulneración de una norma o plan superior, nada impedirá la modificación de esa norma o plan superior y la aprobación posterior de un reglamento o plan igual al antes anulado, tras todo el procedimiento exigido ${ }^{32}$;

siones de la parte actora, con la fundamentación jurídica y argumentación que funda la Sentencia, para desembocar en el fallo y concretos pronunciamientos en ésta contenidos. La función jurisdiccional de decir el Derecho, presupuesto necesario de la ejecución, no permite una consideración aislada de cada uno de dichos momentos y actos procesales, sino que requiere su valoración unitaria y global, pues ésta es la que permite extraer, con mayor grado de certeza, el genuino alcance y significación de las determinaciones del órgano jurisdiccional y de los efectos jurídicos, de naturaleza formal o material, que deben producir aquéllas» (entre otras, SSTC 240/1998, de 15 de diciembre, FJ 3; 83/2001, de 26 de marzo , FJ 4; 146/2002, de 15 de junio, FJ 3, o STC 116/2003, de 16 de junio, FJ 3)". Si esto es así en general para determinar el alcance de la ejecución, también puede serlo para delimitar el ámbito de la contradicción con las sentencias de que habla el art. 103.4 LJCA.

30 Lo dice la STS de 19 junio 2013 (casación 2713/2012 Ar. 5629): "Aunque por sentencia pueden anularse las previsiones de los planes, el titular de la potestad de ordenación territorial o urbanística conserva todavía opciones que excluyen la aplicación automática de las normas anteriores, porque en el ejercicio de esas potestades pueden ser aprobados nuevos instrumentos, y con más razón cuando la causa determinante de la invalidez decretada por sentencia haya sido debida a defectos de tramitación del instrumento...". Vid. C. AGOUÉS MENDIZÁBAL, "La modulación de los...", cit., pp. 402-403.

31 Así, no se ha encontrado inconveniente, por ejemplo, a que anulado el cese de un funcionario por falta de motivación, se considere bien ejecutada la sentencia dictando nueva resolución de cese ahora motivada, pese a que se le daban efectos retroactivos (STC 83/2001, de 26 de marzo); o a que, anulada la calificación urbanística de unos suelos por falta de motivación, un plan posterior la reiterase ahora con esa motivación, máxime cuando las circunstancias podían haber cambiado (STS 1997/2016 de 6 de septiembre; casación 3365/2014; Ar. 5776).

32 Por eso la STS de 8 de noviembre de 2012 (casación 4561/2011; Ar. 10656) no vio obstáculo a que, anulado un plan especial porque el plan general preveía un estudio de detalle, se volviese a aprobar el plan especial tras haber modificado el plan general que ya sí establecía como posible esa figura de planeamiento: "Se hace ahora lo que debió hacerse entonces, a saber, proporcionar desde el planeamiento general la cobertura normativa suficiente para que el posterior desarrollo encuentre su perfecto acomodo en el plan general (...) Conviene reparar que cuando la nulidad declarada obedece a la elección del instrumento de planeamiento y a la falta de acomodo del plan especial respecto de lo dispuesto en el plan general, la modificación posterior de éste de superior rango para incorporar lo que establecía ese plan especial declarado nulo no puede ser calificado como un caso elusivo del cumplimiento de la sentencia (...) Por el contrario (...) es un ejercicio que se enmarca dentro de la discrecionalidad propia del planificador...". Véase igualmente 
etc. Hasta cabe afirmar que en estos casos, lejos de contradicción con la sentencia, se cumple escrupulosamente ${ }^{33}$.

Y en lo que atañe a los hechos relevantes para la sentencia su cambio sustancial puede impedir que el nuevo acto o reglamento caiga en el art. 103.4 LJCA por falta del requisito objetivo incluso aunque sea de contenido igual al del anulado por la sentencia ${ }^{34}$. Así, por ejemplo, la sentencia que anule la calificación de unos terrenos no obsta a que se realice lícitamente esa misma calificación si han cambiado las circunstancias $^{35}$.

STS de 18 de diciembre de 2008 (casación 1214/2007; Ar. 7346): plan parcial que infringía el plan general en cuanto a superficie mínima de parcela; pero licitud de la posterior modificación del plan general para decir lo que antes decía el plan parcial.

33 En relación a planes de urbanismo y con evocaciones kantianas, es ilustrativa la STS 1997/2016, de 6 de septiembre (casación 3365/2014; Ar. 5776): "No puede desprenderse de nuestra jurisprudencia, desde luego, la existencia de un imperativo categórico que venga a impedir, siempre y sin excepción, la reproducción de la ordenación anulada por virtud de una sentencia firme"; "Habrá que estar a la entidad y naturaleza del vicio determinante de la anulación" y, por tanto, a la "ratio decidendi de las resoluciones judiciales" anulatorias; "Al amparo de su potestad de planeamiento, la Administración puede ejercitar una opción diferente y llevar a efecto una ordenación distinta, pero también le es dable proponer una ordenación planteada en términos similares (y aun idénticos, añado) a la que había sido anulada".

34 Esto lleva a acotar la permanencia en el tiempo del valor de los fallos y a evitar que se produzca una "congelación" de la situación. Es lo que, como explicó ORTEGA ÁLVAREZ, L., "La ejecución de sentencias", Fusticia Administrativa, $\mathrm{n}^{\circ}$ extraordinario dedicado a la Ley de la Jurisdicción Contencioso-Administrativa (1999), pp. 156-157, permite que la Administración ante nuevas circunstancias haga "una nueva valoración del interés general volviendo a incidir sobre la materia que fue anteriormente objeto del fallo judicial, sin que se interprete que con ello" se actúa en contra de la sentencia.

Es sugerente la STS de 29 de octubre de 2001 (casación 2543/1996; Ar. 454 de 2002). Antes se había anulado judicialmente un plan de ordenación del tráfico de Sevilla. El TS contesta que "la eficacia de la sentencia no opera cuando la situación jurídica por ella definida se ha modificado por hechos o actos legítimos posteriores que no pudieron ser contemplados por la decisión judicial"; y que "ha de tenerse en cuenta que la nulidad apreciada judicialmente fue por no haberse seguido, en su día, por el Ayuntamiento el procedimiento establecido para dictar la disposición general que suponía dicho Plan; pero, en manera alguna, se desapodera a la Administración, sino que, por el contrario, se reconoce explícitamente la potestad de la Corporación municipal para la ordenación del tráfico (...). Por consiguiente, cabe entender que las decisiones municipales sobre la circulación de determinadas calles del centro de Sevilla sean independientes del Plan anulado, y que fueron adoptadas en razón a circunstancias distintas, incluso, sobrevenidas (...) pues no se pueden congelar las previsiones circulatorias porque fuera anulado un determinado Plan de Ordenación circulatoria y de estacionamiento por razones procedimentales". Como se habrá observado, esta sentencia también juega con el vicio que propició la anulación judicial. Incluso en otros pasajes descarta que se diera el requisito subjetivo. Pero lo esencial es que habían cambiado las circunstancias y es eso lo que ahora interesa destacar.

35 STS de 5 de julio de 2012 (casación 2922/2010; Ar. 7735): "El hecho de que una sentencia anule una determinada calificación urbanística por falta de motivación no impide que, de forma indefectible, la misma calificación puede volver a plantearse en el futuro al amparo de circunstancias y motivaciones distintas (...) En definitiva, siendo la esencia del ius variandi la adaptación del contenido del planeamiento a las exigencias, cambiantes, que en cada momento demanda el interés general, el hecho de que determinada calificación no esté justificada en un momento dado no impide que posteriormente sí puede estarlo si las 
Suele considerarse arquetipo del acto o reglamento que cumple este requisito objetivo del art. 103.4 LJCA el que reproduce al anulado. Pero, como acabamos de ver, no siempre que se dicte un acto o reglamento que resuelva en el mismo sentido del anulado se dará tal requisito objetivo: no se dará si no incurre en el mismo vicio que llevó a su anulación judicial o si han cambiado sustancialmente las circunstancias fácticas determinantes. Aun así, sí que pudiera caer en este vicio del art. 103.4 LJCA si se pretende retrotraer los efectos del nuevo acto al momento en que se dictó el anulado: al menos, esa retroactividad sí podría considerarse contraria a la sentencia; no sería nulo el nuevo acto o reglamento pero sí su retroactividad ${ }^{36}$.

$\mathrm{Y}$ en sentido contrario hay actos y reglamentos de contenido material diferente al del acto o reglamento anulado que sí que cumplen este requisito objetivo ${ }^{37}$.

Así sucede, por lo pronto, cuando se aprueban reglamentos o actos que, aun sin reproducir al anulado, se basan en él o le dan algún tipo de efectos ${ }^{38}$; o se los dan a algunos de los producidos a su amparo antes de la anulación ${ }^{39}$.

También es habitual considerar que cumplen este requisito objetivo los nuevos reglamentos (o planes) que alteran el marco jurídico que tuvo en cuenta la sentencia como base para pronunciar su fallo y que convierten en lícito lo que la sentencia consideró ilícito ${ }^{40}$. Cosa distinta es que puede que pese a ello no entren en el art. 103.4

circunstancias fueran distintas, pues lo contrario supondría una especie de petrificación de la potestad de planeamiento incompatible con la satisfacción del interés general y una lesión a la potestad reglamentaria...".

36 STS de 30 de septiembre de 2003 (casación 8614/1999; Ar. 8221): “... debemos proclamar que la facultad de otorgar efectos retroactivos a un acto administrativo (...) no puede aplicarse al proceso judicial de ejecución utilizándola para enmendar las consecuencias naturales de una declaración judicial de nulidad del acto administrativo...". Precisamente el que el nuevo acto no tenga efectos retroactivos demuestra que la nulidad pronuniada por la sentencia no es meramente platónica.

37 Se lee por ejemplo en la STS de 17 de septiembre de 2010 (Ar. 709 de 2011): "Es cierto que no concurre identidad entre los dos instrumentos de planeamiento -Plan Especial de 1999 y Plan Especial de 2004- pero tal coincidencia no es lo que se exige en el art. 103.4 LJCA, que se limita imponer los requisitos (de que) la disposición general nueva sea contraria a lo resuelto en sentencia y que se haya dictado con la finalidad de eludir su cumplimiento".

38 Por ejemplo, se dicta providencia de apremio para ejecutar el acto anulado o se aprueban nuevos planes de desarrollo del anulado o se otorga licencia en aplicación del plan anulado. Respeto a esto último dice la STS de 12 de febrero de 2008 (casación 5953/2005, Ar. 1885) que se puede pedir la nulidad de la licencia concedida en aplicación del plan anulado en ejecución de la sentencia que anuló el plan "de conformidad con lo establecido en el art. 103.4 LJCA. Y no podría decirse que se estaría entonces decidiendo cosa no juzgada, ya que tal problema es propio de la ejecución".

39 Eso también contradice materialmente la sentencia. Porque, dada la retroactividad de la nulidad, los actos dictados en aplicación del nulo también son, en general, nulos; aunque ello tiene excepciones como las derivadas del art. 73 LJCA.

40 Son numerosas las sentencias que declaran la nulidad del art. 103.4 LJCA en estos supuestos, sobre todo ante cambios en los planes urbanísticos. Entre ellas ofrece un ejemplo bien simple y claro la STS 
LJCA por no cumplir el requisito subjetivo que precisamente cobra en esa hipótesis más sentido y relevancia para distinguirlo de los casos en que el cambio normativo es causa legal de imposibilidad de ejecutar sentencias (art. 105.2 LJCA).

Pero los tres géneros enumerados (actos que reproducen al anulado con sus mismos vicios y en iguales circunstancias; actos que dan efectos al anulado; y reglamentos que cambian el marco normativo de la sentencia) no agotan los que pueden cumplir el requisito objetivo del art. 103.4 LJCA. Hay muchas formas de contradecir sentencias y no cabe encerrar en unos cuantos tipos todas las que pudieran subsumirse en el art. 103.4 LJCA ${ }^{41}$. Aun así, no cabe desorbitar el ámbito de esta causa de nulidad confundiendo las ejecuciones aparentes con las reales aunque hagan que las sentencias estimatorias tengan menos efectos prácticos de los que en principio cabría pensar. Luego insistiremos en ello.

\section{B) El requisito subjetivo: la finalidad de eludir el cumplimiento de la sentencia}

El segundo requisito, aunque criticado por la doctrina ${ }^{42}$, ha sido destacado por la jurisprudencia que habla de un "componente subjetivo", de un "elemento teleológico o intencional", de un "animus", y lo exige siempre.

Los tribunales consideran que esta finalidad de eludir la sentencia constituye una modalidad de desviación de poder ${ }^{43}$. Por esa asimilación a la desviación de poder

de 24 de abril de 2014 (casación 5639/2011; Ar. 2456): anulada una licencia para un comercio en local bajo rasante porque lo prohibía el plan, se modifica éste para permitir ese uso e imposibilitar la ejecución de la licencia.

41 Como dice GONZÁLEZ PÉREZ, J., Comentarios a la Ley de la Ley de la Furisdicción Contencioso-Administrativa, Civitas, Cizur Menor, 8 a ed., 2016, p. 968, "los procedimientos utilizados por la Administración para lograr la inejecución de los fallos son infinitos. En todos los países los administradores muestran una habilidad extraordinaria para conseguir sus fines y lograr que prevalezca su criterio. Se ha llegado a decir que la Administración, a la que, por otra parte, se le reprocha su falta de imaginación, hace gala en este aspecto de una ingeniosidad notable". Siendo pues infinitos los artificios de que la Administración puede valerse para eludir las sentencias, no conviene encorsetar el art. 103.4 en unos determinados tipos de actos.

42 Así, HUERGO LORA, A., "La permanencia de un viejo problema: la reiteración de los actos administrativos anulados como forma de incumplimiento indirecto de las sentencias, con especial referencia a los efectos de los recursos de casación en interés de Ley”, RAP, núm. 156 (2001), pp. 296 a 298). También CLAVERO ARÉVALO, M. (2003: 931) reprochó al art. 103.4 la exigencia de este animus "pues debe bastar que la actuación sea contraria a los pronunciamientos para que se produzca la nulidad. Añadir el requisito de la desviación de poder supone introducir un factor de inseguridad innecesario (...). Por otra parte, con independencia de la gravedad de tal finalidad, lo fundamental es que la actuación sea contraria a los pronunciamientos de la sentencia aunque no se haya dictado con la finalidad de eludir el cumplimiento...". Asimismo BAÑO LEÓN, J. M. (2016: 97-98 y 100), XIOL RÍOS, J. A. (2016: 722) y GARGÍA LUENGO, J., "Los supuestos de nulidad de pleno derecho establecidos al margen de la Ley de Procedimiento Común", $R A P, \mathrm{n}^{\circ} 159$ (2002), p. 144.

43 Dijo la STS de 31 de enero de 2006 (casación 8263/2003; Ar. 4356): “... lo que (...) debe demostrarse es, justamente, la mencionada finalidad de inejecutar la sentencia con el nuevo y posterior acto o disposición, o, dicho de otro modo, la concurrencia de la desviación de poder en la nueva actuación 
el TS ha excluido del art. 103.4 LJCA las actuaciones regladas ${ }^{44}$. Conforme a ello, el ámbito por antonomasia de esta causa de nulidad sería el de las actuaciones en ejercicio de potestades discrecionales: así, a los límites generales de toda discrecionalidad se sumaría otro adicional, el de no ejercerse con la finalidad de elusión de sentencias. Y efectivamente de ese modo lo explican muchas veces los tribunales ${ }^{45}$.

Es de discutible acierto esa identificación de la finalidad de eludir la sentencia con una desviación de poder ${ }^{46}$. Y, aunque se acepte esa asimilación a la desviación

$\overline{\text { administrativa, en relación con el pronunciamiento de la sentencia”. La misma identificación con la des- }}$ viación de poder luce, entre otras muchas, en las SSTS de 21 de junio de 2005 (casación 4936/2002; Ar. 8968), 28 de diciembre de 2006 (casaciones 384/2004, Ar. 4582 de 2007), 18 de diciembre de 2008 (casación 1214/2007, Ar. 7346), 6 de abril de 2011 (casación 1602/2007, Ar. 2962), 16 de diciembre de 2011 (casación 171/2008, Ar. 2830 de 2012), 19 de febrero de 2013 (casación 5525/2010; Ar. 3195), 18 de diciembre de 2014 (casación 2847/2012, Ar. 6823), 1774/2016 de 14 julio (casación núm. 3620/2015, Ar. 3799), 1955/2016, de 21 de julio (casación 3916/2015, Ar. 3916), 882/2017, de 22 de mayo (casación 2042/2016, Ar. 3491), 996/2017, de 5 de junio (casación 2271/2016, Ar. 3658) y 1280/2017, de 18 julio (casación 1264/2016, Ar. 3967).

También la doctrina asume la asimilación a la desviación de poder. Por todos CLAVERO ARÉVALO, M. (2003: 929 a 931), FONT i LLOVET, T. (2003: 824) y SUAY RINCÓN, J. (2018: 44).

44 Por eso, por ejemplo, el TS ha descartado que pueda darse esta nulidad en el acuerdo de suspensión automática de licencias ante la aprobación inicial de planes en sustitución de otro anulado. Así, SSTS 1280/2017 de 18 julio (casación núm. 1264/2016; Ar. 3967) y 1646/2017, de 31 de octubre (casación 1677/2016; Ar. 4812). Ello pese a que, tras la anulación judicial de un plan con la consecuente reviviscencia del plan anterior, la suspensión de licencias puede convertir en una quimera esa reviviscencia y dar al traste con las expectativas de los demandantes que consiguieron la sentencia anulatoria de un plan que parece quedar burlada. Como al elaborar un nuevo plan sustitutorio del redivivo, la suspensión de licencias es reglada, no se incurriría en el vicio del art. 103.4 LJCA. Con todo, según parte de la doctrina no hay nada que excluya a radice la desviación de poder en el ejercicio de potestades regladas.

45 Muestra de ello, entre otras, es la STS de 28 de septiembre de 2009 (casación 2573/2005; Ar. 7345): “... aparte de los límites que acotan el ejercicio de la discrecionalidad administrativa en cualquier ámbito y de los diferentes cauces para su fiscalización jurisdiccional (necesaria observancia del procedimiento, respeto a los hechos determinantes, control de los elementos reglados de la decisión, interdicción de la arbitrariedad, etc.), en el caso que nos ocupa es obligado destacar la concurrencia de un factor que necesariamente opera como un límite especialmente relevante a la discrecionalidad. Nos referimos, claro es, a la existencia de una resolución judicial firme (...) que al haber declarado la nulidad de una licencia, la procedencia de demoler la edificación amparada en ella y el derecho de los demandantes en esos litigios a que tales pronunciamientos se ejecuten, configuran un estado de cosas que no puede ser ignorado". La idea estaba ya en la célebre STC 167/1987, de 28 de octubre, en la que la vulneración de la sentencia anterior se había producido ejerciendo la discrecional potestad de autoorganización administrativa: se explicaba que ninguna sentencia puede eliminar "las facultades organizativas que ostenta la Administración Pública sus propios servicios" pero que "tales facultades de organización no pueden ser ejercidas en directo menoscabo o detrimento de la santidad de la cosa juzgada y con lesión del derecho (...) a la efectiva tutela judicial".

46 No creo acertada esa identificación: puede que la Administración ejerza una potestad para lograr el interés general previsto en el ordenamiento y que, sin embargo, sí que tenga la finalidad de eludir la sentencia. Es más, a veces se trata de eludir el cumplimiento de una sentencia para conseguir que el resultado final sea adecuado a los intereses generales para cuya consecución esta atribuida la potestad 
de poder, como mínimo hay que añadir que es una desviación de poder con un régimen especial: no sólo por ser determinante de nulidad (no de anulabilidad, como es la regla general, art. 48.1 LPAC) sino porque, en contra de la rigurosa exigencia de prueba que normalmente se requiere para estimar la existencia de tal desviación, aquí se presume iuris tantum cuando concurre el requisito objetivo ${ }^{47}$.

En efecto, no se carga al actor con la prueba de esa finalidad desviada sino que recae sobre la Administración la demostración de que, pese a la contradicción con la sentencia, su finalidad no es eludirla. Lo sintetiza bien la STS de 29 de mayo de 2015 (casación 3301/2014; Ar. 3155):

“... hemos establecido, expresa o implícitamente, la inversión de la carga de la prueba, trasladando a la Administración el deber de probar que tales nuevos actos o disposiciones no persiguen como finalidad propia lograr la inejecución de la sentencia"

ejercida: no habrá, pues, propiamente, desviación de poder. El requisito subjetivo del art. 103.4 LJCA se mueve en un plano diferente a la desviación de poder. Se ve con claridad en los casos en que la Administración se sirve de la potestad de planeamiento urbanístico. A este respecto son sugerentes las explicaciones de GÓMEZ-FERRER RINCÓN, R., La imposibilidad de ejecución de sentencias en el proceso contencioso-administrativo, Civitas, 2008, p. 321: “... puede ser (...) que la planificación urbanística se haya cambiado para hacer imposible la ejecución de la sentencia, pero (...) para proteger un determinado bien o valor constitucional, como puede ser el derecho a la vivienda o la protección de la riqueza"; "la fuerza normativa de dichos bienes o valores constitucionales" justifica que la Administración pueda ejercer su potestad de planeamiento para salvaguardarlos. Lo que hará la Administración al cambiar el plan en esa hipótesis será "en realidad (...) ajustar la normativa urbanística de acuerdo con el interés público urbanístico". Luego no habrá desviación de poder, aunque la jurisprudencia dominante subsuma tales supuestos en el art. 103.4 LJCA. Cosa distinta es que los tribunales partan de que el interés público supremo es el de la ejecución de la sentencia -por estar conectado con un derecho fundamental y con la noción de Estado de Derecho- y que ante él todos los demás intereses públicos sucumban gracias al art. 103.4 LJCA. Pero eso no significa que la Administración haya incurrido en desviación de poder. Por lo demás, negar la identificación entre el animus del art. 103.4 LJCA y la desviación de poder salva mejor las críticas de SANTAMARÍA PASTOR, J. A.(2014: 197 y ss.), que subraya las diferencias de régimen entre la finalidad elusiva de la sentencia y la desviación de poder, diferencias a las que de inmediato nos referimos. En suma, la consideración de la finalidad elusiva del art. 103.4 LJCA como una forma de desviación de poder ni es acertada desde el punto de vista conceptual ni desde el de las consecuencias de régimen jurídico: es una complicación sin fundamento que sólo genera confusión.

47 O sea, según CHINCHILLA PEINADO, J. A. "La ejecución aparente del fallo de las sentencias contencioso-administrativas en el ámbito urbanístico. Un balance tras 10 años de vigencia de la Ley 29/1998", Revista de Derecho Urbanístico y Medioambiente, núm. 245 (2008), p. 77, se presume esta finalidad, o sea, se presume la desviación de poder, cada vez que el nuevo reglamento o acto impide la ejecución de la sentencia. Crítico con esta presunción en contra de la Administración se muestra GALÁN GALÁN, A. (2006: 142-143); la defiende RUIZ BURSÓN, F. J., "Las innovaciones en el planeamiento urbanístico como causa de imposibilidad legal para la ejecución de sentencias", RGDA, nº 33 (2013), pp. 26-27. 
Son numerosas las SSTS que acogen esta inversión de la carga de la prueba ${ }^{48}$. E incluso en ocasiones parece que no se trata sólo de que cuando el nuevo acto o reglamento sea impugnado se demuestre en el proceso que su finalidad no es la eludir la sentencia sino de que ello conste ya en la motivación del acto ${ }^{49}$. Y el tribunal, que puede presumir la concurrencia de esa finalidad espuria, no puede simplemente negarla con argumentos genéricos ${ }^{50}$. No obstante, escapan de esta presunción las

48 Sobre todo ante la aprobación de nuevos planes de urbanismo. Reseñemos sólo algunas notables. - STS 1996/2016, de 6 de septiembre (casación 1215/2015; Ar. 4817): "Cuando se trata de valorar y determinar si la finalidad de la aprobación de un cambio de planeamiento tiene por finalidad eludir el cumplimiento de una sentencia judicial, se produce una inversión de la carga de la prueba, correspondiendo a la Administración autora de dicha modificación acreditar que la misma obedece a una finalidad general de mejora de la ordenación urbanística, ajena al incumplimiento de lo acordado por una sentencia judicial firme".

En el caso de la STS de 13 mayo 2014 (casación 2417/2013; Ar. 3644) se partía de la anulación de una licencia en cuya virtud se había construido un edificio. El Ayuntamiento aprobó después un plan parcial y alegó que con éste devenía imposible la ejecución de la sentencia (demolición). Pero el TS afirmó que “... no se ha demostrado que la modificación del Plan Parcial que el Ayuntamiento opone a la ejecución de la sentencia tuviera otra finalidad que la de eludir su cumplimiento. En este sentido conviene señalar que (...) no es al recurrente y sí, en todo caso, a la Administración a quien corresponde acreditar que la modificación del planeamiento no tiene por finalidad sortear la ejecución de la sentencia. Y en el presente caso, no ha justificado que las determinaciones que integran el contenido de la modificación tengan un objetivo distinto del señalado". Con ello entendió que el nuevo plan parcial "tuvo por finalidad eludir el cumplimiento de la sentencia firme dictada (...) y en consecuencia debe ser anulado, de conformidad con lo dispuesto en el art. 103.4 de la Ley de esta Jurisdicción".

-Según la STS de 19 de febrero de 2013 (casación 5525/2010; Ar. 3195), si un nuevo plan va a impedir la ejecución de una sentencia es necesaria una especial "motivación esmerada y rigurosa" para enervar la sospecha de su finalidad espuria.

La STS de 28 de septiembre de 2009 (casación 2573/2005; Ar. 7345) señala que, ante la previa anulación de una licencia, "para introducir una nueva ordenación urbanística cuya aprobación comporta la inefectividad de esos pronunciamientos jurisdiccionales o hará inviable su cumplimiento, la Administración debe necesariamente realizar un especial esfuerzo para justificar el cambio de ordenación llamado a tener tan grave consecuencia, $y$, en fin, para disipar cualquier sospecha de que el planeamiento se altera con la intención de impedir el cumplimiento de la sentencia".

Igualmente SSTS de 8 de noviembre de 2012 (casación 4561/2011; Ar. 10 656); de 10 de mayo de 2007 (casación 3786/2004, Ar. 8062); de 12 de julio de 2004 (casación 1644/2002; Ar. 4242); de 4 de mayo de 2004 (Ar. 5298); de 10 de diciembre de 2003 (casación 2550/2001, Ar. 107 de 2004)

A veces, sin embargo, el TS se muestra algo más exigente con la prueba de la finalidad defraudatoria o, al menos, hace declaraciones que tratan de conciliar esta jurisprudencia con la general sobre la prueba de la desviación de poder. $\mathrm{E}$ incluso ha aceptado ciertos "indicios de inexistencia de desviación de poder". Así, SSTS de 23 de diciembre de 2010 (casación 2970/2006; Ar. 1033 de 2011) y de 18 de diciembre de 2014 (casación 2847/2012; Ar. 6823).

49 Así, STS de 17 de junio de 2009 (casación 1135/2008; Ar. 2009) sobre la que después volveremos.

50 Así se infiere de la STS 1955/2016, de 21 de julio (casación 3916/2015; Ar. 3916) que anuló los autos del tribunal de instancia que dieron por bueno un nuevo Estudio de Detalle aprobado en sustitución del anteriormente anulado porque no explicaron suficientemente que no tuviera finalidad elusiva de modo 
actuaciones anteriores a la sentencia supuestamente burlada, casos para los que se exige una prueba cumplida de la finalidad elusiva ${ }^{51}$.

Merced a esa presunción iuris tantum se suaviza el requisito subjetivo ${ }^{52}$. Pero nunca se elimina: su concurrencia es necesaria y su falta impide declarar la nulidad del art. 103.4 LJCA ${ }^{53}$. Más todavía: su presencia es lo que distingue los supuestos de nulidad del art. 103.4 LJCA de aquellos otros en los que una actuación administrativa posterior podrá ser causa lícita de imposibilidad legal de ejecución conforme al art. 105.2 $\mathrm{LJCA}^{54}$.

que le remitió las actuaciones "para que examine y decida con libertad de criterio" si el nuevo plan es o no ajustado a Derecho y, en concreto, si se aprobó con la finalidad de eludir la sentencia. Es, además, una apreciación que corresponde al juzgado o tribunal que conozca en primera instancia y cuya valoración sólo muy limitadamente puede cambiarse en apelación o casación. Dice a este respecto la STS 113/2019, de 4 de febrero (casación 3965/2017; Ar. 354): “... en principio la apreciación de las circunstancias de las que se desprende la intención u objetivo de eludir el cumplimiento de la sentencia corresponde al órgano de primera instancia competente para la ejecución del fallo, valoración que no puede sustituirse o revisarse si no se justifica la arbitrariedad o irracionalidad de la misma...".

51 Afirma la STS 1997/2016, de 6 de septiembre (casación 3365/2014; Ar. 5776) que en los supuestos de actuaciones administrativas anteriores a la sentencia pero producidas vaticinando el resultado adverso "se impone un grado de demostración de la finalidad elusiva más intenso que el habitual". En la misma dirección SSTS de 12 de marzo de 2015 (casación 1881/2014, Ar. 3626) y de 18 de diciembre de 2014 (casación 2847/2012; Ar. 6823). Asimismo la STS de 19 de junio de 2013 (casación 2713/2012) dice que "en este supuesto de actos anteriores para evitar la ejecución esperada, la aplicación del artículo 103.4 $4^{\circ}$ LJCA exige un grado de demostración de la finalidad elusiva más intenso que cuando se trata de actos dictados con posterioridad al fallo". Y la STS de 23 de diciembre de 2010 (casación 2970/2006; Ar. 1033 de 2011) declaró que "es indicio de inexistencia de desviación de poder si la sentencia se dicta con posterioridad a la aprobación del nuevo planeamiento". Por todo ello dijo ya la STS de 28 de marzo de 2006 (casación 8466/2002; Ar. 3138) que "resulta muy difícil imputar tal vicio a la Orden aprobatoria de la Revisión del PGOU cuando aún faltaban dos meses para que se dictara la sentencia".

52 Incluso hay sentencias que casi no aluden a él. Por ejemplo, STS de 30 de abril de 2008 (casación 7159/2004, Ar. 5375) que considera incursa en la nulidad del art. 103.4 la convalidación de una expropiación sin referencia alguna al ánimo defraudatorio. Tampoco se insiste en ese fin en la STS de 15 de diciembre de 2010 (casación 3699/2008, Ar. 3350) para declarar la nulidad de un plan especial dictado en sustitución de un estudio de detalle anulado judicialmente.

53 Que este elemento subjetivo es siempre necesario se ve notoriamente en la STS de 21 de junio de 2005 (casación 4936/2002; Ar. 8968): en ese caso se reconoció que se había contradicho la sentencia puesto que se habían calificado como urbanos suelos que según la sentencia anulatoria de un plan no tenían los servicios para ello; y, aun así, en ejecución de dicha sentencia, no anuló conforme al art. 103.4 LJCA porque no apreció que los actos en cuestión "se dictaran, precisamente, con la finalidad de eludir el cumplimiento de la sentencia".

54 Así, GALÁn GALÁN, A. (2006: 146), dice que si falta el requisito subjetivo de la finalidad elusiva "estaremos ante un supuesto de imposibilidad de ejecución (...) Este elemento subjetivo (...) se convierte, de este modo, en el criterio determinante de la aplicación del art. 103.4 ó del art. 105.2 LJCA". En igual dirección CHINCHILLA PEINADO, J. A. (2008: 74), deduce de esa exigencia subjetiva del art. 103.4 LJCA, que si falta tal finalidad, el acto o disposición sería legal: “... sensu contrario supone el reconocimiento de la legalidad de aquellos otros actos o disposiciones que se hayan dictado o adoptado sin que concurra dicha finalidad" que podrán determinar la "imposibilidad de ejecución de la sentencia en los términos del 


\section{C) ¿Qué sucede si falta alguno de los requisitos?}

Tal vez estos elementos objetivo y subjetivo podrían haberse establecido como alternativos de forma que bastase uno u otro para incurrir en nulidad ${ }^{55}$. Pero claramente el art. 103.4 LJCA ha optado por configurarlos como acumulativos y a ello, como se ha visto, se atiene la jurisprudencia. Por tanto, si falta alguno de los dos no cabrá apreciar esta causa de nulidad ${ }^{56}$. Cosa distinta es que sí que pueda bastar alguno de esos dos requisitos para que la actuación administrativa tenga algún otro vicio invalidante distinto del específico del art. 103.4 LJCA. Así podría decirse que, como el requisito subjetivo se asimila a una desviación de poder y como ésta por sí sola es determinante de invalidez (arts. 48.2 LPAC y 70.2 LJCA), bastaría para conseguir su anulación. De hecho, así lo ha insinuado el TS ${ }^{57}$. Sobre todo se ha sostenido que el mero elemento objetivo de la contradicción con la sentencia debería ser bastante para poder anular la actuación administrativa ${ }^{58}$. Y, en efecto, no cabe descartar que, al margen del art. 103.4, la contradicción con la sentencia sin ánimo elusivo sea suficiente para detectar otro vicio invalidante: en principio, vicio de anulabilidad; y en su caso incluso de nulidad si se entiende vulnerado el derecho fundamental a la tutela

art. 105.2 LJCA”. Y FONT i LLOVET, T. (2003: 825) dice: “... no debe olvidarse que sólo es esa finalidad elusiva (...) lo que se considera ilegítimo en grado de nulidad, puesto que no debe pensarse que se produce un bloqueo o congelación de una determinada ordenación por el hecho de haber sido objeto de un pronunciamiento judicial. La Administración no pierde sus potestades, lo que no puede es ejercerlas para incumplir una sentencia”.

55 O seguramente habría sido muy correcto haber añadido el requisito subjetivo únicamente para los casos en los que la Administración altera el marco normativo en que se desenvolvió la sentencia para así distinguir, sólo en tal género de supuestos, los afectados por el art. 103.4 y los que puedan entrar en el art. 105.2 LJCA como causas lícitas de imposibilidad de ejecución de sentencias. En los demás, bastaría el requisito objetivo. Es lo que apunta HUERGO LORA, A. (2001: 297-298).

56 En contra, HUERGO LORA, A. (2001: 299) llega a decir que, "pese al tenor literal del art. 103.4 LJCA", son nulos de pleno derecho conforme a ese precepto todos los actos contrarios a la sentencia "sin necesidad de indagar su intención". También CASTILLO BLANCO, F., "La ejecución propia e impropia de sentencias en el ámbito contencioso-administrativo", RAAP, núm. 100 (2018), p. 103: propugna que se prescinda de la exigencia de la finalidad y afirma que, aunque la redacción legal "parece involucrar un elemento volitivo (...) dirigido a eludir el cumplimiento del fallo (...), es el contenido material del acto el factor determinante de la infracción de nulidad, independientemente de que concurriese o no tal finalidad".

57 Se ve en la STS de 19 de febrero de 2013 (casación 5525/2010; Ar. 3195): aplica el art. 104.3 LJCA para anular un plan dictado para evitar la ejecución de una sentencia; pero añade: “... aun en el supuesto dialéctico de que se entendiera no estrictamente aplicable el art. 103.4 LJCA (...) siempre cabría apreciar esa desviación de poder mediante la cláusula general del art. 70 de la misma Ley...".

58 BAÑO LEÓN, J. M. (2016: 97-98 y 100), tras censurar la exigencia del animus, concluye que cualquier acto o reglamento contrario a la cosa juzgada es nulo de pleno derecho de acuerdo con el art. 47.1.a) LPAC: sería contrario al derecho fundamental a la tutela judicial efectiva con independencia de que se haya dictado con la finalidad de incumplir la sentencia y del art. 103.4 LJCA. Igualmente dijo XIOL RÍOS, J. A. (2016: 722), que, como los actos contrarios al fallo vulneran el derecho a la ejecución de las sentencias y como éste está comprendido en el derecho a la tutela judicial efectiva del art. $24 \mathrm{CE}$, son nulos de pleno derecho. 
judicial efectiva en su vertiente de derecho a la ejecución de las sentencias [art. 47.1.a) LPAC]. Pero aunque así se acepte habrá de aplicarse con cautelas. De una parte, tal vicio invalidante no cabría argüirlo y estimarlo en el cauce del art. 103.5 LJCA que se contrae a la causa de nulidad del apartado anterior con sus dos requisitos. De otra parte, deberá diferenciarse la actuación administrativa que puramente contraría a la sentencia de aquélla otra que deba considerarse lícita aunque imposibilite la ejecución de la sentencia y que cabrá invocar con éxito en el incidente del art. 105.2 LJCA. Y a decir verdad tal diferenciación, si se prescinde del elemento subjetivo de la finalidad de eludir la sentencia, es sutil y extremadamente difícil ${ }^{59}$.

\section{D) Si se dan los dos requisitos no hay intereses generales que excluyan la nulidad}

Si concurren los dos requisitos expuestos se da la nulidad del art. 103.4 LJCA. Y la actuación administrativa en cuestión no se salvará de esta nulidad aunque persiga proporcionadamente algún fin legítimo. Esto es así no porque la Constitución lo imponga sino porque la legalidad actual no admite causas de inejecución de sentencias por razones de interés público aunque se trate de proteger otros valores constitucionales y de hacerlo con la menor lesión posible al derecho a la tutela judicial ${ }^{60}$. Aquí hay una diferencia entre las actuaciones administrativas y las legislativas: la ley sí que puede impedir la ejecución de sentencias si lo hace proporcionadamente para la tutela de un valor constitucional ${ }^{61}$.

\section{E) ¿Excesos en la aplicación del artículo 103.4 LFCA?}

Incluso reconociendo las variopintas formas que pueden adoptar los actos subsumibles en el art. 103.4 LJCA, haciendo repaso de las sentencias que lo aplican puede tenerse la impresión de que su ámbito se ha extendido demasiado. Es difícil hacer una exposición sistemática de lo que acaso sean excesos. Citaré algunos ejemplos en los que creo atisbarlos.

- STS de 17 de junio de 2009 (casación 1135/2008; Ar. 2009). Una sentencia anuló el acto por el que se privaba a una persona de la presidencia de honor de un

59 Recuérdese que, como hemos destacado en nota anterior, GALÁN GALÁN, A. (2006: 146) y CHINCHILLA PEINADO, J. A. (2008: 74) ponen precisamente la frontera entre el art. 103.4 y art. 105.2 LJCA en la existencia o no del requisito subjetivo, o sea, en la finalidad elusiva de la sentencia.

60 A este respecto es fundamental GÓMEZ-FERRER RINCÓN, R. (2008: 275 y ss). Acaso podría sostenerse que cuando la actuación administrativa persigue la protección de algún valor constitucional no se da el requisito subjetivo del art. 103.4. Pero la jurisprudencia apenas deja margen para tal elucubración: si, aunque para proteger otro interés general, detecta la intención de inejecutar la sentencia, la condena impasible por el art. 103.4 LJCA.

61 FJ 12 STC 231/2015: "las disposiciones adoptadas por la representación popular" sólo vulnerarán el art. $24 \mathrm{CE}$ "cuando resulte incontestable que la ley ha venido a hacer imposible el cumplimiento del fallo y que lo ha hecho además (...) al margen de todo fin legítimo o con desproporcionado sacrificio del interés tutelado por el pronunciamiento judicial". Véase también FJ 15 de la STC 231/2015. 
Colegio Profesional porque se había acordado como sanción, sanción ilegal por no estar prevista en norma alguna. La sentencia aclaraba que "no prejuzga ni condiciona cuantos ulteriores acuerdos puedan tomarse en relación con la privación del honor en su día concedido, que en ningún caso podrá ser impuesta como sanción". El Colegio en cuestión procedió para cumplir la sentencia a restituir al sujeto en su condición de presidente honorario. Pero acto seguido lo destituyó otra vez. Según la sentencia reseñada la nueva destitución incurre en la nulidad del art. 103.4 LJCA: “... la finalidad de eludir el cumplimiento de la sentencia (...) debe pregonarse siempre que ese nuevo acto contrario carezca de toda motivación, pues al carecer de ella debe entenderse que su motivación o razón de ser es la misma a la que obedeció el acto anterior anulado". Pero, al margen de la finalidad, ¿realmente la nueva destitución contradecía la sentencia anterior? ¿Era una ejecución aparente? No lo veo.

- STS de 26 de marzo de 2014 (casación 3790/2011; Ar. 2418). Previamente un tribunal había anulado la licencia para construir unos apartamentos porque no existía ni estaba previsto un vial que los comunicara adecuadamente. Después se modificó el PGOU para prever ese vial. Pero el TS entiende que esa reforma del PGOU está incursa en el vicio del art. 103.4 LJCA porque "no tiene otra finalidad que dejar sin efecto los pronunciamientos de una sentencia firme declarativa de la ilegalidad de una licencia urbanística para construir una serie de viviendas". Pero esa modificación del PGOU ¿vulneraba la sentencia o la cumplía superando la falta que aquélla detectó? Me parece más bien lo segundo.

- STS de 26 de febrero de 2015 (casación 555/2014; Ar. 2082) ${ }^{62}$. Previamente otra sentencia había anulado la liquidación de tasa que la Comisión del Mercado de las Telecomunicaciones había girado a Telefónica por autorizaciones generales y licencias individuales de casi 12 millones de euros por no haber justificado que ese importe se correspondiera con los gastos de gestión administrativa. La CMT cumplió la sentencia: devolvió la cantidad cobrada e intereses (más de 13 millones). Pero luego hizo una nueva liquidación, ahora por sólo unos 6 millones de euros, basada motivadamente en los costes de gestión. Esta STS anuló la nueva liquidación en aplicación del art. 103.4 y 5 LJCA ¿De verdad esa segunda liquidación vulneraba la anterior sentencia? ¿Es justo que Telefónica no pagase nada? ¿Es eso lo que se desprendía de la sentencia anterior? No lo creo.

- A estos tres botones de muestra, súmense las sentencias que consideran que cualquier convalidación de lo anulado por una sentencia anterior entra en la nuli-

62 Hay otra casi idéntica de la misma fecha que resuelve la casación 754/2014 (Ar. 1781) con la única diferencia de referirse a otro ejercicio. En ambas se mezcla confusamente el art. 103 LJCA con una discutible jurisprudencia según la cual no cabe practicar liquidaciones sustitutivas de las previamente anuladas que, aunque se acepte, debería quedar al margen del art. 103.4 LJCA. Sobre estas dos sentencias, SESMA SÁNCHEZ, B., La nulidad de las liquidaciones tributarias, Aranzadi, Cizur Menor, 2017, pp. 206 y 442. 
dad del art. 103.4 LJCA: no sólo en casos de actos o reglamentos declarados nulos ${ }^{63}$ sino también, con acierto más discutible, cuando se trataba de actos anulables con el argumento de que, una vez anulados por sentencia, no cabe su convalidación ${ }^{64}$. Similar idea ha tenido una aplicación rigurosa ante planes de urbanismo de manera que, tras su anulación judicial, se entiende que ni siquiera cabe conservar los trámites anteriores e independientes del vicio ${ }^{65}$ sino que hay que comenzar desde el

63 STS de 30 de abril de 2008 (casación 7159/2004; Ar. 5375): se da la nulidad del art. 103.4 y se acuerda en incidente del 103.5 en la convalidación de una expropiación que había sido declarada nula por incompetencia (la Comunidad Autónoma hizo la ocupación y el acta previa de ocupación de una expropiación estatal): como era nula no cabía convalidación que se considera incursa en la nulidad del 103.4 sin aludir nunca al ánimo defraudatorio o similar.

64 Lo dicen las SSTS 4 de febrero de 2004 (casación 1479/2002, Ar. 828) y de 9 de octubre de 2007 (casación 1451/2005, Ar. 7740). Se habían anulado licencias: una vez porque se autorizaba una gasolinera en una parcela que no alcanzaba la dimensión mínima; en otro por falta de informe jurídico. Pero se convalidó el acto (porque se compraron los terrenos contiguos hasta alcanzar la parcela mínima, por emisión a posteriori del informe antes omitido). Y las SSTS dicen que eso no cabe. Porque una cosa es que los actos anulables puedan ser convalidados y otra es que, una vez que han sido judicialmente anulados, puedan seguir siendo convalidados: "La posibilidad de que la Administración convalide los actos anulables subsanando los vicios de que adolezca, deja de operar, en sí misma, una vez que el acto ha sido anulado jurisdiccionalmente". Ello porque "el acto anulado no es un acto anulable, sino que ya no es un acto, y no se puede convalidar lo que no es". O sea, la convalidación sana al enfermo pero no resucita al muerto. Y estas SSTS consideran que los actos de convalidación del anulado por la sentencia tienen el vicio del art. 103.4 LJCA (y se puede declarar en la vía del 103.5). Ello porque como dice la segunda de ellas ese art. 103.4 sirve para "impedir que la Administración demandada pretenda ejecutar el acto anulado o quiera deducir de él cualquier tipo de efectos" o dar "al acto anulado cualquier tipo de eficacia". Lo mismo se reitera en la STS de 17 de octubre de 2007 (casación 2218/2005; Ar. 7324). Conviene añadir a esta radical jurisprudencia que al menos se ha aclarado que distinta de la convalidación es la mera utilización en un nuevo procedimiento tramitado para producir otra decisión de la documentación material generada para el anterior procedimiento. Así, STS de 28 de diciembre de 2006 (casación 384/2004, Ar. 4582 de 2007): "... la nulidad decidida no impide que la documentación material utilizada en el anterior Proyecto" de compensación sea "susceptible de reutilización...: se trata de datos objetivos -como ocurre con las determinaciones de las fincas, sus cabidas, ubicación, dimensiones- perfectamente aprovechables en el nuevo Proyecto, no obstante la anulación del anterior".

65 Entre otras, SSTS de 11 de marzo de 2008 (casación 1056/2006); de 12 de noviembre de 2010 (casación 6045/2009; Ar. 8294); de 18 de noviembre de 2011 (casación 5883/2008; Ar. 2297 de 2012); dos de 28 de septiembre de 2012 (casación 1009/2011, Ar. 9762; y casación 2092/2011, Ar. 9519); de 13 de diciembre de 2013 (casación 1003/2011; Ar. 8198); de 12 de mayo de 2015 (casación 1920/2013; Ar. 2862); de 18 de noviembre de 2015 (casación 3194/2014; Ar. 5633); 1997/2016, de 6 de septiembre (casación 3365/2014; Ar. 5776); 2003/2016, de 20 de julio (casación 4402/2012; Ar. 4818). En esta última, por ejemplo, se dice: “... no se puede subsanar, enmendar o convalidar el plan nulo (...) La misma naturaleza normativa de las determinaciones del plan declaradas nulas hace inviable la aplicación de los principios de conservación y convalidación...”. O, por sólo citar otra de las recientes, se explica en la STS 1997/2016, de 6 de septiembre (casación 3365/2014; Ar. 5776) que no cabe subsanar, enmendar o convalidar el plan nulo (en el caso nulo por falta de motivación) sino que se "requiere la tramitación de un procedimiento desde su inicio". Da cuenta cumplida de esta jurisprudencia a la que critica SORO MATEO, B., "Sobre el alcance de la anulación de los planes urbanísticos por defectos de forma. La anulación de la Revisión del PGOU de Cartagena", Revista de Derecho Urbanístico y Medio Ambiente, no 315 (2017), pp. 134 a 162. Vid también BA- 
principio $^{66}$ y, por lo que aquí importa, que si la Administración se sirve de parte de la tramitación anterior estará vulnerando la sentencia anulatoria e incurriendo en la nulidad del art. 103.4 LJCA. Para colmo, en esa jurisprudencia sobre prohibición de convalidaciones se maneja un concepto de éstas amplísimo que no coincide en absoluto con una verdadera subsanación ni supone darle efectos retroactivos y que hasta incluye el dictado de nuevos actos con efectos propios, no con la resurrección de los efectos del acto anulado.

Así las cosas, parece complicado distinguir entre lo que sería vulneración de la sentencia y lo que más bien puede considerarse su cabal acatamiento volviendo a aprobar un acto o reglamento que ya no tenga los vicios que llevaron a la anulación del anterior. Es cierto que esto segundo puede hacer que la sentencia previa tenga pocos efectos prácticos, pero eso no justifica echar mano del art. 103.4 LJCA. Una cosa es dar al acto o reglamento anulado efectos (lo que efectivamente cae dentro del art. 103.4 LJCA) y otra distinta es dictar ahora un nuevo acto o reglamento que, sin los vicios que se imputaron al primero, produzca similares efectos, efectos que son los de éste, no los de aquél. Esto último no vulnera la sentencia anterior ${ }^{67}$. Es más, insisto, puede ser una forma exquisita de cumplimiento. Igualmente, si se estableciera que tras la anulación de una sanción no cabe imponer otra (por ejemplo, porque se entendiera que eso vulnera el non bis in ídem procedimental) o que tras la anulación de una liquidación tributaria no cabe hacer otra, esa segunda sanción o liquidación no sería contraria a la sentencia sino a esa regla que prohibiese dar a la Administración una segunda oportunidad. Asimismo, si se cree que no cabe convalidar el acto anulado y ni siquiera conservar los trámites no viciados -lo que, por cierto, no tiene ninguna

SSOLS COMA, M., "La asimilación de los planes de urbanismo a normas reglamentarias y problemática jurídica de su anulación judicial", en SORIA MARTÍNEZ, G. y BASSOLS COMA, M. (Coords.), Los efectos de la nulidad de los instrumentos de planeamiento urbanístico, Aranzadi, 2017, pp. 73-74; SANTAMARÍA PASTOR, J. A., "Muerte y transfiguración de la desviación de poder: sobre las sentencias anulatorias de los planes", RAP, no 195 (2014), pp. 212 a 214; y GIFREU FONT, J., "La reconsideración de la naturaleza normativa de los instrumentos de planeamiento: ¿una panacea para modular el alcance y efectos del dogma de la nulidad absoluta de los reglamentos ilegales?", en AGUDO GONZÁLEZ, J. (Coord.), Nulidad del planeamiento y ejecución de sentencias, Bosch, Barcelona, 2018, pp. 38-39.

66 Vid. SANTAMARÍA PASTOR, J. A., "Una imprevista disfunción del sistema urbanístico: la mortalidad judicial de los planes", Práctica Urbanística, no 141 (2016), pp. 10-11; y GONZÁLEZ SANFIEL, A. M., "Límites a la declaración de nulidad de los planes", en F. LÓPEZ RAMÓN y F. VILLAR ROJAS (Coords.), El alcance de la invalidez de la actuación administrativa, AEPDA/INAP, 2017, pp. 413 y 416.

$67 \mathrm{Al}$ menos, no la vulneran si no se retrotraen los efectos del nuevo acto al momento en que se dictó el anulado. Cuando se establezca tal retroactividad sí que podría considerarse que esa retroactividad vulnera el art. 103.4 LJCA, tal y como se explicó antes y se ejemplificó con la STS de 30 de septiembre de 2003 (casación 8614/1999; Ar. 8221). Y el que el nuevo acto realmente es otro y no resurrección o convalidación del anterior se pone de relieve no sólo por el hecho de que sus efectos se producirán desde que se dicte, no desde que se dictó el anulado, sino también porque este deberá someterse a la legislación ahora vigente, no a la que estaba en vigor cuando se produjo el acto anulado. 
justificación y lo rechaza el $\mathrm{TC}^{68}$ - la actuación convalidatoria sería ilegal pero no contraria a lo fallado en la sentencia anterior.

Tal vez ante las críticas por las insuficiencias que otrora mostraban las ejecuciones sentencias se haya pasado al extremo opuesto; quizá deslumbrados y subyugados por el derecho fundamental a la ejecución de las sentencias se haya desorbitado. Acaso en la lucha contra las ejecuciones aparentes estén cayendo actuaciones administrativas que cumplen la sentencia aunque comporten que tenga escasos efectos prácticos. Incluso es posible que se esté confundiendo la atención que hay que prestar a la causa petendi con las meras expectativas que haya fantaseado el demandante victorioso.

La verdad es que hay afirmaciones de los tribunales y de la doctrina (invariablemente insatisfecha con la práctica judicial ${ }^{69}$ ) que, aunque no alcancen a justificar los excesos que hemos vislumbrado, sí que contienen en germen ideas que llevan a exagerar la ejecución de las sentencias y cada una de sus piezas, también la del art. 103.4 LJCA. Se afirma así que todos los preceptos sobre ejecución de las sentencias deben interpretarse extensivamente ${ }^{70}$; que para acotar lo que debe entrar en la ejecución hay que interpretar el fallo, no literalmente o conjuntamente con la ratio decidendi, sino con un criterio finalista y que se debe propender a inferir de él todas sus consecuencias y a agotarlas en la ejecución sin obligar a interponer nuevos re-

68 Así se lee en su sentencia 231/2015, de 5 de noviembre, FJ 4: "La subsanación y consiguiente convalidación de actos y normas constituye, como es conocido, una institución que no es ajena al Derecho administrativo (...), sin que ello implique una forma de dejar sin sanción la infracción de ciertas normas jurídicas, sino todo lo contrario, pues la subsanación pretende cumplir y hacer valer la norma jurídica que se infringió cuando se dictó el acto subsanable (...) Si el contenido de la disposición anulada es en sí mismo legal, la Administración siempre podrá volver a establecerla mediante una nueva declaración de voluntad libre de cualquier vicio procedimental, conservando incluso los trámites válidos empleados en la elaboración del declarado nulo. Cuando la Administración obra así, no comete desacato respecto a la sentencia que ha anulado el acto ni vulnera el derecho fundamental a la tutela judicial efectiva de la persona fisica o jurídica que solicitó y obtuvo esa anulación".

69 Vid. FERNÁNDEZ RODRÍGUEZ, T. R., "El artículo 130.4 LJ no les gusta a los jueces", en SÁNCHEZ BLANCO, A., DOMÍNGUEZ BERRUETA DE JUAN, M. A., y RIVERO YSERN, J. L. (Coords.), El nuevo Derecho Administrativo. Libro homenaje al Profesor Dr. Enrique Rivero $Y_{\text {sern, Ratio Legis y }}$ Universidad de Salamanca, Salamanca, 2011, pp. 139 a 146; y FERNÁNDEZ TORRES, J. R., "La ejecución de sentencias sigue siendo un auténtico quebradero de cabeza veinte años después de la aprobación de la LJCA", RAAP, n 100 (2018), p. 175, que censura "la resistencia de los Jueces y Tribunales a enjuiciar en sede de ejecución, con fundamento en lo dispuesto en el art. 103.4 LJCA, los actos y disposiciones dictados por la Administración (...) y su preferencia (...) por proponer a los ejecutantes la interposición de un nuevo recurso...".

70 Por ejemplo, STC 167/1987: “...los órganos judiciales (...) deben interpretar y aplicar las Leyes (en lo relativos a sus preceptos sobre ejecución de sentencias) en el sentido más favorable para la efectividad del derecho fundamental" a la tutela judicial. Y BAÑO LEÓN, J. M. (1998: 725): "los preceptos comentados no consienten interpretaciones restrictivas". 
cursos $^{71}$; que el fallo "tiene un efecto expansivo"72; que la contradicción exigida por el art. 103.4 LJCA no ha de ser "frontal o directa"73; etc. Aunque ninguna de estas afirmaciones son en sí mismas erróneas, en conjunto y aplicadas sin tasa conducen a ensanchar desmesuradamente la ejecución de sentencias y nuestra causa de nulidad.

\section{F) Frenos a los excesos}

Frente a ello, además de insistir en lo que hemos expuesto sobre el cumplimiento del requisito objetivo y en las sentencias más atinadas que entonces citamos, conviene hacer algunas observaciones, por más que sean obvias. La primera es que tan importante como la plena ejecución de las sentencias es la intangibilidad del fallo que prohíbe, entre otras cosas, acordar en ejecución lo que no se desprende inequívocamente de la sentencia ${ }^{74}$. La segunda es que inflar la ejecución de las sentencias no

71 Es bien conocida esa jurisprudencia constitucional que se contiene, entre otras, en las SSTG 167/1987, 148/1989, 121/2007, 11/2008 y 50/2015; así como en otras muchas del TS, como es destacadamente la 1996/2016, de 2 de marzo (casación 1626/2015; Ar. 940). Transcribamos sólo un pasaje de la STC 50/2015, de 5 de marzo, que la sintetiza: “... doctrina de este Tribunal dictada en relación con la denominada garantía de interpretación finalista del fallo, que infiera de él todas sus naturales consecuencias para la cabal ejecución de lo ordenado, interpretándolo de acuerdo con la fundamentación y con el resto de los extremos del pleito. Así, a la hora de valorar si los Autos judiciales de ejecución respetan o no la Sentencia de la que traen causa, tiene siempre en cuenta tanto el fallo como la fundamentación jurídica de la resolución judicial, hemos destacado que la interpretación y aplicación del fallo no ha de ser literal, sino finalista, en armonía con el contenido total de la Sentencia (STC 148/1989, de 21 de septiembre, FJ 4).

72 STS de 19 de junio de 2013 (casación 2713/2012; Ar. 5629): "en el caso de la anulación del planeamiento general (...) el fallo declarativo que dispone la nulidad tiene un efecto expansivo derivado de la exigencia de realización completa del fallo sobre el planeamiento secundario, con independencia de si su aprobación hubiese sido (...) anterior a la sentencia anulatoria". También la STS de 2 de marzo de 2016 (casación 1626/2015; Ar. 940): se incluyen en la ejecución "todas las cuestiones directamente relacionadas con la efectividad del fallo dirigidas al restablecimiento de la legalidad urbanística quebrantada por (...) las infracciones que determinaron su nulidad. Sólo cuando este derecho se haya hecho realidad o (...) cuando se hayan controlado (...) los eventuales obstáculos (...) podrá afirmarse que la ejecución está agotada". Ni creo acertado que ese "efecto expansivo" de la nulidad de planes ni que en la ejecución deba agotarse todo lo necesario para restablecer la legalidad urbanística.

73 XIOL RÍOS, J. A. (2016: 723): "Esta oposición no es menester que sea frontal o directa, sino que basta con que sea encubierta, siempre que objetivamente se descubra la incompatibilidad entre el acto y el cumplimiento del fallo". Se da este requisito si la actuación administrativa "vacía de contenido" la sentencia. GALÁN GALÁN, A. (2006: 140): “... no es necesario que esta oposición sea frontal o directa sino que es posible que sea indirecta o encubierta, siempre que objetivamente pueda comprobarse la incompatibilidad entre esa actuación de la Administración y la ejecución de la sentencia”.

74 Como explica, por todos, EZQUERRA HUERVA, A. (2014: 939), cuando se habla de la "intangibilidad del fallo" hay que afirmar que ese principio "opera de modo bidireccional, toda vez que protege por igual a ambas partes procesales -y a cualesquiera afectados...- frente a una ejecución apartada de lo estrictamente decidido en la sentencia". De modo que la intangibilidad del fallo no permite dejarlo corto en perjuicio de una parte; pero tampoco sacar de él más de la cuenta en perjuicio de la otra. Y esto último es lo que parece haber sucedido en muchos casos. Téngase en cuenta, además, que según el TG (por ejemplo, sentencia 219/1994) también el condenado/ejecutado, incluyendo a la Administración, tiene un derecho 
es siempre un avance del Estado de Derecho sino que puede constituir un riesgo ${ }^{75}$, incluso para el derecho a la tutela judicial efectiva de los otros sujetos que, sin ser partes ni haberse podido defender, pueden ver comprometidos sus intereses en ejecuciones judiciales desbocadas que pretendan resolver allí todo lo que de alguna forma tenga remota relación con lo fallado ${ }^{76}$. Y la tercera es que no se pueden llevar a la ejecución de sentencias (por ejemplo, a las que anulen un acto o un reglamento) todas las pretensiones que se basen en su cosa juzgada material: precisamente se consagra el efecto prejudicial de la cosa juzgada en todo género de procesos porque se parte que muchas pretensiones que encuentran apoyo en una sentencia previa firme deben ser objeto de otros procesos, no de la ejecución de la primera sentencia; no se tratará de ejecutar lo decidido en la sentencia sino de decidir otra cosa aunque en el silogismo judicial juegue como premisa incontrovertible la sentencia anterior ${ }^{77}$. Si siempre ha habido sentencias más moderadas y prudentes (algunas de las que hemos expuesto al hablar del requisito objetivo) o que incluyen aclaraciones tendentes a contener la ejecución -y, por ende, el art. 103.4 LJCA- dentro de límites razonables, creo que puede detectarse en las más recientes un reforzamiento de esa línea. Al menos, conviene la cita de la STS 1774/2016 de 14 julio (casación núm. 3620/2015. Ar. 3799) que limita el art. 103.4 así:

fundamental a que en la ejecución no vaya más allá de lo que exige el fallo. Este derecho, sin embargo, tiene escasa protección en los recursos de amparo. Ello porque el TC parte de reconocer al tribunal que haya dictado la sentencia la interpretación de su fallo y, por tanto, la decisión sobre lo que lo vulnera o no, salvo que haya procedido de forma irracional (por ejemplo, SSTC 139/2012, FJ 3, y 211/2013, FJ 3). Salvo esos extremos, el TC dará por bueno lo que el tribunal sentenciador haya decidido que significa el fallo y lo que lo contradice, pese a que sea excesivo. Así que, con pocos límites y control por el TC, los tribunales ordinarios son dueños y señores a la hora de decidir lo que vulnera sus sentencias y lo que entra en el art. 103.4 LJCA.

75 BAÑO LEÓN, J. M. (2016: 99), ha llegado a decir que "la exacerbación del derecho a la tutela judicial efectiva, en su vertiente de derecho a la ejecución de las sentencias, ha ampliado de manera notable los poderes de ejecución del juez hasta el punto en que es difícil saber si no se está afectando al principio de división de poderes...".

76 Dicen, por ejemplo, las SSTS 475 y 476/2018, de 21 de marzo, que quedan fuera de la ejecución las cuestiones no decididas por el fallo "porque podría ser menoscabado el derecho a la tutela judicial de terceros al margen del procedimiento declarativo correspondiente, del que no se les puede privar".

77 Por eso no puede compartirse la tesis de HUERGO LORA, A. (2001: 299-302): “... el conjunto de cuestiones a las que se extiende (la) autoridad de cosa juzgada pueden ser ventiladas en el incidente de ejecución, sin necesidad de iniciar un nuevo proceso declarativo...”. Y después: “... lo que nunca es necesario es que el recurrente «victorioso» acuda a estos procesos (declarativos) ulteriores para hacer valer los efectos de la cosa juzgada". No es así: el efecto de cosa juzgada y los efectos ejecutivos son y permanecen distintos; aquél tiene mayor ámbito que éste. Y no es aceptable que cualquier conflicto en el que la cosa juzgada juegue con su simple efecto prejudicial se lleve a la ejecución de la sentencia. Ni siquiera sumando la cosa juzgada a los efectos materiales de las sentencias anulatorias ello es admisible. Los peligros de esa tesis suben de grado si se trata de sentencias anulatorias de reglamentos o planes, supuesto en el que llevaría a convertir las ejecuciones en causas generales inmanejables. 
“... resulta necesario que los actos, cuya nulidad se pretende, sean actos conectados de forma clara con la actividad de ejecución, por relacionarse de forma directa con el contenido del fallo de la sentencia"78.

\section{LA VÍA DEL ARTÍCULO 103.5 LJCA}

\section{Naturaleza}

\section{A) Un incidente de ejecución que encierra un proceso de cognición}

Pese a que formalmente se realice en ejecución de sentencia y como incidente de ejecución, no es un proceso de ejecución. Se trata materialmente de un proceso de cognición: la pretensión que necesaria y esencialmente se ejerce es de anulación (por tanto, una pretensión de cognición, no una pretensión ejecutiva); y el auto que estime el incidente será en sustancia declarativo ${ }^{79}$. No se trata de llevar a la realidad material lo juzgado, de usar la coacción para ello; por el contrario, se trata de una nueva declaración de nulidad. No se pasa del ius dicere al ius facere, sino que se permanece en el ius dicere, aunque sea pare decir algo distinto de lo que ya dijo la sentencia ${ }^{80}$. A fuer de exactos, no se hace ejecutar lo juzgado, sino que se juzga otra vez, ahora en relación a un acto distinto del que fue objeto del proceso principal y aunque sobre la base de lo ya juzgado ${ }^{81}$. Lo que sí es posible es que el auto que estime el incidente

78 Por supuesto que esto no es completamente nuevo ni ajeno a la jurisprudencia del TC. Por ejemplo, decía ya la STC 219/1994: “... con ocasión de los incidentes de ejecución no es posible resolver cuestiones que no hayan sido abordadas ni decididas en el fallo o con las que éste no guarde una inmediata o directa relación de causalidad, pues, de otro modo, no sólo se vulnerarían las normas legales que regulan la ejecución sino que podría resultar menoscabado, asimismo, el derecho a la tutela judicial efectiva de las otras partes procesales o de terceros [SSTC 125/1987, fundamentos jurídicos $4 .^{\circ}$ y $5 .^{\circ} ; 167 / 1987$, fundamento jurídico 2. ${ }^{\circ} ; 215 / 1988$, fundamento jurídico $3 .^{\circ}, 148 / 1989$, fundamento jurídico 4. ${ }^{\circ}$ ]". Nótese que no sólo exige, como mínimo, una inmediata o directa relación con lo fallado sino que, en línea con lo que hemos dicho más arriba, afirma que lo contrario, lejos de favorecer la tutela judicial efectiva, vulneraría la de otras partes o la de terceros. También la STG 231/2015 orienta en la misma dirección al hablar de consecuencias del fallo que deriven "necesariamente de él de modo directo, inmediato e inequívoco" y excluir las que no reúnan esos requisitos del derecho a la ejecución de sentencias.

79 Ello sin perjuicio de que, como veremos, la demanda incidental y declaración anulatoria pueda ir acompañada de pretensiones y declaraciones de condena.

80 Lo más que puede decirse es lo que afirma CLAVERO ARÉVALO, M. (2003: 932): “... no se ejecuta la sentencia sino que se impide que se inejecute".

81 En realidad, ya esto no es un fenómeno aislado en la LJCA. Lo mismo sucede con la extensión de la sentencias a sujetos distintos de las partes que admiten los arts. 72.3, 110 y 111 LJCA: también aquí se trata de un proceso declarativo aunque configurado formalmente como incidente de ejecución. Por todos, PÉREZ ANDRÉS, A. A., Los efectos de las sentencias de la jurisdicción contencioso-administrativa, Aranzadi, 2000, pp. 259 y 272; y MAGALDI, N., "La extensión de los efectos de las sentencias", en EZQUERRA HUERVA, A. y OLIVÁN DEL CACHO, J. (Dirs.), Estudio de la Ley de la furisdicción Contencioso-Administrativa, Tirant lo Blanch, 2014, pp. 1050-1051. 
pueda eventualmente ser objeto de una auténtica ejecución (o, en su caso, dar lugar a una declaración de imposibilidad de ejecución), como veremos.

\section{B) Incidente en la ejecución de sentencias de condena y en la de las merodeclarativas}

Desde luego este incidente de ejecución cabe ante sentencias de condena. Eso no tiene nada de extraño. Lo prodigioso es que se puede producir -y se produce con frecuencia- ante sentencias puramente declarativas o constitutivas como son las que sólo declaran la nulidad o anulan un acto o un reglamento ${ }^{82}$. Eso lleva admitir que una sentencia merodeclarativa tenga ejecución, lo que parece un fenómeno paranor$\mathrm{mal}^{83}$. Antes no pusimos reparo a que una sentencia merodeclarativa diera lugar a la nulidad del art. 103.4. Lo raro es que dé lugar a ejecución. No sólo choca con la ortodoxia más asentada sino con la lógica. Deriva de la naturaleza de las cosas que una sentencia puramente declarativa o constitutiva no es susceptible de ejecución. Así lo aceptó el $\mathrm{TC}^{84}$ y así lo confirma la $\mathrm{LEC}^{85}$. Aunque en la LJCA no hay una declaración general en ese sentido ${ }^{86}$, lo mismo afirma la doctrina respecto a las sentencias contencioso-administrativas ${ }^{87}$. A lo sumo pueden dar lugar a la llamada ejecución

82 Ya recién aprobada la LJCA de 1998, decía REBOLLO PUIG, M. (1998: 528), que, por excepción, "en lo contencioso-administrativo muchas sentencias estimatorias que no son propiamente de condena también podrán dar origen al incidente de ejecución. No sólo no se encontrará en los arts. 103 y ss. LJCA limitación a las sentencias de condena, sino que con normalidad es necesaria para las declarativas y constitutivas".

$83 \mathrm{Y}$, aunque con más dudas, hasta sería imaginable este incidente de ejecución ante sentencias desestimatorias (o sea, confirmatorias del acto impugnado) si es que se acepta, como antes apuntamos, que también esas sentencias pueden dar lugar a la nulidad del art. 103.4 LJCA. Y la ejecución de una sentencia desestimatoria sería un fenómeno aún más misterioso.

84 Por ejemplo, dijo ya en su sentencia 32/1982 y reiteró en la 67/1984 y en la 109/1984, de 26 de noviembre, FJ 2.A): "El derecho a la tutela judicial efectiva comprende (...) el de obtener la ejecución de las sentencias, dejando a salvo naturalmente el caso de las meramente declarativas...". Nótese: no sólo quedaban a salvo sino que lo hacían "naturalmente". Y no hay aquí nada contrario a la tutela judicial efectiva porque las pretensiones meramente declarativas o constitutivas se satisfacen plenamente con la sentencia declarativa o constitutiva que, como suele decirse, "consuman la tutela judicial".

85 En la LEC se enumera entre los títulos ejecutivos a las "sentencias de condena" (art. 517.2.1 ${ }^{\circ}$ ), no a las demás; expresamente establece que "no se despachará ejecución de las sentencias meramente declarativas ni de las constitutivas" (art. 521.1); y cuando una sentencia es constitutiva pero tiene también un pronunciamiento de condena, sólo esto último es objeto de ejecución (art. 521.3). Por ello autoriza al ejecutado a oponerse a la ejecución alegando "nulidad radical del despacho de la ejecución por no contener la sentencia (...) pronunciamiento de condena...” (art. 559.1.3º. Igualmente sólo las sentencias de condena pueden ejecutarse provisionalmente (art. 526).

86 Sí hay algunos preceptos sobre la ejecución que se refieren sólo a sentencias de condena (así, arts. 106 y 108.1), pero no hay una exclusión radical y general de las sentencias merodeclarativas como la que contiene la LEC.

87 Véase por todos BAÑO LEÓN, J. M. (2016: 89, nota 6, a 92); CASTILLO BLANCO, F. (2018: 95); y EZQUERRA HUERVA, A. (2014: 992). También, HUERTA GARICANO, I. (2000: 104-105), aunque ya introduce matices no sólo por el art. 103.5 LJCA sino, dice, porque hay sentencias anulatorias que 
impropia $^{88}$. Entonces, ¿cómo es posible que el incidente de ejecución del art. 103.5 quepa ante sentencias merodeclarativas? La explicación está en lo que acabamos de afirmar: no es que se haya producido el portento de que las sentencias declarativas tengan ejecución; es que el incidente del art. 103.5 no es un proceso de ejecución sino de cognición, aunque metido con calzador en la ejecución. Es así como se ha logrado la cuadratura del círculo.

Esto se hizo a mayor gloria del derecho a la tutela judicial efectiva. No es obra totalmente novedosa del art. 103.5 LJCA, sino, como ya advertíamos al principio, heredera de la jurisprudencia anterior que ya avanzó en la posibilidad de combatir en ejecución de sentencias declarativas las actuaciones administrativas contrarias a ellas. La situación ortodoxa y conforme a las clásicas instituciones procesales no se consideró satisfactoria en el orden contencioso-administrativo porque la Administración, sirviéndose de su autotutela y de su consecuente posibilidad de dictar actos y reglamentos con presunción de validez, podía obligar a los particulares a instar una y otra vez sucesivos procesos; frente a ello se construyó la extraña vía de anular en ejecución de sentencias merodeclarativas las actuaciones de la Administración contrarias a lo fallado ${ }^{89}$. Surgió así un nuevo "privilegio en menos" de la Administración (que sufre ejecuciones de sentencias más amplias y severas que los demás sujetos) para compensar su "privilegio en más" por antonomasia, el de la autotutela. De aquella construcción es descendiente el art. 103.5 LJCA y la jurisprudencia que lo aplica; una jurisprudencia en la que ocasionalmente se deja sentir la consciencia de que lo más corriente es que esas sentencias merodeclarativas no tengan ejecución (salvo la impropia $)^{90}$ y del extraño fenómeno a que se da lugar ${ }^{91}$, pero que, a la postre, ha

comportan la necesidad de "hacer desaparecer todas las consecuencias derivadas del acto anulado". Esto último supone a veces convertir sentencias merodeclarativas en sentencias de condena, lo que es de justificación discutible. En similar dirección HUERGO LORA (2001: 292, nota) afirma que en el contencioso-administrativo "la distinción entre sentencias declarativas y las de condena es, a veces, sólo lingüística" porque en muchos casos también aquéllas obligan a la Administración "a llevar a cabo determinadas actuaciones, y no sólo a abstenerse de actuar en contra de lo dispuesto en la sentencia".

88 Ejecución impropia a la que, paralelamente al art. 521.2 LEC, alude el art. 107 LJCA: publicación en boletines oficiales e inscripción en registros. Véase CASTILLO BLANCO, F. (2018: 124-127).

89 XIOL RÍOS, J. A. (2016: 721-722).

90 Es representativa la STS 1997/2016, de 6 de septiembre (casación 3365/2014; Ar. 5776): argüía la Administración que la ejecución de una sentencia que anula un plan se cumple con la publicación de su fallo (la ejecución impropia); y el TS dice que puede ser así, que eso es lo normal, pero que "no siempre habrá de ser así"; no lo es cuando la Administración realice "actuaciones, jurídicas o materiales, encaminadas a entorpecer las resoluciones judiciales adoptadas o a tratar de menoscabar su virtualidad. Y de ser efectivamente así tales actuaciones pueden ser objeto, desde luego, del consiguiente reproche en sede judicial en el marco de un incidente de ejecución de sentencias".

91 Lo refleja la lúcida STS de 29 de octubre de 2001 (casación 2543/1996; Ar. 454 de 2002):“... es preciso perfilar la incidencia que en la ejecución puede tener el que la sentencia sea de condena o sea declarativa o constitutiva, pues estas últimas han sido tradicionalmente consideradas como sentencias que 
asumido e interiorizado como normal este pasmoso fenómeno. Lo refleja la STS de 9 de octubre de 2007 (casación 1451/2005; Ar. 7740). Ante la alegación de que una ejecución había vulnerado diversas normas procesales porque "la sentencia de cuya ejecución se trata es meramente declarativa y no incluyó ningún pronunciamiento de condena”, contestó flemática:

"No es cierto que la sentencia que anula un acto administrativo no tenga nada que ejecutar. Esa sentencia expulsa de la vida jurídica al acto anulado, y en ejecución de la misma el Tribunal sentenciador puede controlar e impedir que la Administración demandada pretenda ejecutar el acto anulado o quiera deducir de él cualquier tipo de efectos. Aunque no lo diga el art. 107.1 LJCA, esa conclusión es inherente al derecho a una tutela judicial efectiva (art. $24 \mathrm{CE}$ ) que incluye el derecho a la ejecución de las decisiones jurisdiccionales. Pues carecería de sentido que quien ha obtenido la anulación de un acto administrativo mediante sentencia firme tuviera que iniciar otro pleito distinto para lograr que la Administración no diera después al acto anulado cualquier tipo de eficacia" ${ }^{\prime 2}$.

Vale. Pero conste que eso sólo se incluye en el art. 24 CE cuando se trata de sentencias merodeclarativas contra la Administración ${ }^{93}$. Además, pese a todo, subsis-

originan la denominada ejecución impropia, ya que producen efectos por la mera declaración judicial de nulidad o de anulabilidad del acto o disposición impugnada, y sólo serían susceptibles de una ejecución propia aquellas que condenan a la Administración al cumplimiento de una determinada prestación. Tal tesis, sin embargo, debe ser objeto de algunas precisiones, ya que la mera conclusión de que no precisan ejecución alguna las sentencias que se limitan a declarar la nulidad de un acto administrativo (declarativas) o a anular un acto administrativo (constitutivas) está alejada de la realidad del proceso contencioso-administrativo. Pues, (...) no es posible ignorar que, incluso cuando la pretensión es sólo de anulación, el que un particular pueda hacer valer un fallo estimatorio de tal naturaleza frente a la supremacía de la Administración y frente a terceros, puede exigir una actividad ejecutiva. Y, en cualquier caso, el propio pronunciamiento judicial anulatorio es susceptible de quedar desvirtuado por una ulterior actuación administrativa constitutiva de la llamada inejecución indirecta...". Esta sentencia, aunque posterior a la LJCA de 1998, todavía no la aplica ni por tanto se sirve del art. 103.5 LJCA sino de la jurisprudencia que fue su precedente. Pero lo mismo se reproduce ya en otras posteriores: SSTS de 19 de junio de 2007 (casación 11258/2004; Ar. 4833) y de 4 de marzo de 2011 (casación 3996/2010; Ar. 2269).

92 Lo mismo, por ejemplo, en STS de 17 de octubre de 2007 (casación 2218/2005; Ar. 7324). En igual línea la STS de 10 de julio de 2007 (casación 9743/2004, Ar. 6692) dice que, aunque en principio la sentencia que sólo anula un acto se puede entender ejecutada con la mera declaración de nulidad, puede no ser así cuando la Administración vuelve a dictar un acto con el mismo vicio (en el caso, el acto de un órgano colegiado anulado por no estar convocado algunos miembros que se vuelve a tomar tras nueva sesión en que supuestamente tampoco se convocó a esos miembros).

$93 \mathrm{Si}$, por ejemplo, una sentencia civil declara la nulidad de un contrato y sólo eso porque sólo eso se pidió en la demanda, la parte que tenga interés en la restitución de lo entregado en virtud de ese contrato no podrá pedirlo en ejecución de sentencia sino que deberá instar un nuevo proceso declarativo. Y nadie ha visto en esto violación alguna del derecho a la tutela judicial efectiva. 
ten algunas diferencias entre la ejecución de esas sentencias y las de condena ${ }^{94}$. Sea como fuere lo que afirmo es que, no es que el derecho a la tutela judicial efectiva en su vertiente de derecho a la ejecución haya obrado el milagro de que existan sentencias declarativas con ejecución: ha supuesto incluir en la ejecución un nuevo proceso de cognición.

\section{C) Un proceso de cognición sumario}

Es por lo demás un medio de impugnación extraordinario o sumario en el sentido de que está limitado el motivo en que puede basarse: el único vicio que cabe invocar y enjuiciar es el del art. 103.4 LJCA y sólo prosperará cuando se den sus requisitos objetivo y subjetivo. Algunas SSTS han calificado a este incidente de "vía excepcional y privilegiada para obtener una declaración de nulidad absoluta de actos y disposiciones" ${ }^{95}$. Pero lo único que han querido decir con ello es que sólo cabe motivarlo en el art. 103.4 LJCA y, por tanto, con la concurrencia de todos sus requisitos, en especial, el de la finalidad elusiva. Los demás vicios en que incurra el mismo acto o reglamento no tienen cabida en este incidente y habrá que esgrimirlos por otros cauces $^{96}$. O sea, aunque el art. 103.4 no se constriñe a la vía del art. 103.5, sí sucede

94 Diferencias que, a la postre, ha reconocido el TC. Éste pasó de excluir la ejecución de las sentencias declarativas (sentencia 32/1982, ante citada) a decir que el derecho a la ejecución de sentencias "presenta singularidades notables en el caso de las sentencias meramente declarativas" (STC 92/1999, FJ 4). Sobre todo se observa en la STC 231/2015, FFJJ 11 y 12. Allí se recalca que la sentencia de cuya ejecución se trataba era meramente declarativa de la nulidad de un reglamento sin contener condena ni reconocimiento de situación jurídica individualizada; y ello le permite moderar sus efectos y negar que se hubiera vulnerado porque lo que se habría visto perjudicado no era lo realmente fallado sino unas expectativas que "no provendrían inmediatamente del fallo". A este respecto, esta STC supone alguna novedad respecto a sentencias anteriores (por ejemplo, la 50/2015), como observa el voto particular. Véase LOZANO CUTANDA, B. "Convalidaciones legislativas de reglamentos anulados: dos pronunciamientos contradictorios del Tribunal Constitucional (SSTC 50/2015 y 231/2015)", Diario la Ley, núm. 8720 (2016). Sea lo que fuere, lo que aquí importa notar es que esta STC, aunque admite la ejecución de sentencias declarativas, permite deducir algunas diferencias y la necesidad de proceder con especial prudencia para no inferir del fallo lo que no sean nada más que las expectativas que se haya creado el recurrente y que no se derivan necesariamente de él.

95 SSTS 1774/2016 de 14 julio (casación núm. 3620/2015. Ar. 3799), 1955/2016, de 21 de julio (casación 3916/2015; Ar. 3916), y 882 y 996/2017, de 22 de mayo y 5 de junio (casaciones 2042 y $2271 / 2016$, Ar. 3491 y 3658).

96 Así, dice la STS de 8 de noviembre de 2012 (casación 4561/2011; Ar. 10656): en el cauce del art. 103.5 LJCA "no nos corresponde pronunciarnos (...) sobre cualquier vicio de ilegalidad que pueda contener dicha modificación del plan general, que ahora no pueden ser considerados. Todo ello sin perjuicio de la interposición de un recurso contencioso-administrativo independiente y autónomo sobre tal modificación en la que pueda esgrimirse cualquier infracción del ordenamiento jurídico". Por eso afirma la STS de 6 de abril de 2011 (casación 1602/2007; Ar. 2962) que la vía del recurso contencioso-administrativo autónomo ante el órgano jurisdiccional competente será "la vía a seguir en el supuesto de que, junto a esta particular acción de tintes subjetivos (la del art. 103.4), se articulara otra basada en la nulidad material del nuevo acto o planeamiento". Lo mismo en la STS de 29 de septiembre de 2009 (casación 2827/2005; Ar. 325 de 2010); y 
a la inversa que el art. 103.5 está circunscrito a la nulidad del art. 103.4. Por eso, la resolución judicial que se dicte desestimándolo no impide que prospere la pretensión anulatoria fundada en otros vicios y ejercida por otros cauces ${ }^{97}$; esto es, que no tendrá efecto de cosa juzgada material o, más exactamente, sólo lo tendrá respecto de la causa de nulidad del art. 103.4 LJCA, no para el resto de vicios que se imputen a la misma actuación administrativa.

\section{Competencia del juez o tribunal de la ejecución; sus limitaciones}

Dado que la Ley configura este proceso como un incidente de ejecución es lógico que lo primero que establezca es que compete al "órgano judicial a quien corresponda la ejecución de la sentencia"; o sea, al que "haya conocido del asunto en primera o única instancia" (art. 103.1 LJCA). Ello concuerda, además, con el art. 7.1 LJCA: los órganos competentes para conocer de un asunto "lo serán también (...) para hacer ejecutar las sentencias que dictaren...”. Todo, en principio, igual que en el orden civil (art. 545.1 LEG). Si nada más dijera el precepto, el Juzgado o Tribunal que dictó sentencia en primera instancia sería en todo caso el competente para declarar por esta vía la nulidad del art. 103.4 LJCA. Lo sería incluso aunque en general no tuviera competencia respecto a esos actos o reglamentos atacados; esto es, aunque si se interpusiera un recurso ordinario contra ellos la competencia fuese de otro órgano judicial. Así, si un Juzgado hubiera anulado un acto municipal y si el Ayuntamiento aprobara una ordenanza a la que se imputara el vicio del art. 103.4 LJCA, ese mismo Juzgado podría conocer de este incidente en el que le sería posible anular tal ordenanza pese a que quienes como regla general tienen competencia para los recursos contra ordenanzas son los Tribunales Superiores de Justicia. Se habrían excepcionado las reglas generales sobre competencia judicial (las de los arts. 8 a 14

la STS 1997/2016, de 6 de septiembre (casación 3365/2014; Ar. 5776) insiste con profusión de argumentos en la exclusión del incidente del art. 103.5 LJCA de cualquier vicio distinto. Véase CALVO ROJAS, E., "Los planes urbanísticos como disposiciones de carácter general. Problemas que suscita la declaración de nulidad de los instrumentos de planeamiento. Suspensión cautelar de la efectividad de los planes impugnados en vía jurisdiccional", en GARCÍA ENTERRÍA, E., y ALONSO GARCÍA, R. (Coords.), Administración y justicia. Un análisis jurisprudencial: liber amicorum Tomás-Ramón Fernández, Civitas, 2012, I, p. 830.

97 Lo aclara expresamente alguna sentencia. Por ejemplo, la STS de 28 de diciembre de 2006 (casación 384/2004, Ar. 4582 de 2007), tras desestimar la nulidad del art. 103.4 en incidente del art. 103.5 LJCA, dice: "Con ello no estamos diciendo que tal actuación resulte correcta -pues ello no es objeto de este incidente- pero sí que (...) al adoptar los nuevos acuerdos el Ayuntamiento (...) no está realizando actividad alguna (...) con la finalidad de contravenir los pronunciamientos del fallo". Igualmente la STS de 27 de mayo de 2008 (casación 2648/2006; Ar. 3494): desestima la acción de nulidad basada en el art. 103.4 y 5 LJCA contra unas normas forales; pero aclara en su fundamento $5^{\circ}$ que ello no afecta a lo que haya de resolverse en el recurso autónomo contra las mismas normas que habían interpuesto otras entidades pues "... la cuestión de fondo planteada sigue viva y pendiente de resolución...". 
LJCA) para respetar al máximo la regla según la cual el órgano que dictó sentencia en primera o única instancia es el dueño absoluto de la ejecución.

Pero la LJCA no lo quiso así. Y por ello el art. 103.5 termina: “... salvo que careciese de competencia para ello conforme a lo dispuesto en esta Ley" "98. Prevalecen, pues, las reglas generales relativas a competencia de los órganos judiciales (las de los arts. 8 a 14 LJCA) sobre el principio de que el juez del proceso principal es también el de la ejecución. Está claro: en el ejemplo puesto, el Juzgado no puede declarar la nulidad de la ordenanza ni siquiera en el incidente del art. 103.5. La limitación a la competencia del juez de la ejecución es severa ${ }^{99}$. Si no se da esa coincidencia de competencia (esto es, si el órgano judicial de la ejecución no es el competente para enjuiciar en abstracto la actuación con el vicio del art. 103.4) no es que pueda promoverse ante otro órgano judicial este incidente; es que queda cegado por completo este cauce del art. 103.5 LJCA ${ }^{100}$. En nuestro ejemplo: no es que el interesado pueda instar ante el respectivo TSJ este incidente para que declare la nulidad de la ordenanza; es que no puede suscitarlo ante nadie. Ahora bien, esta limitación se suaviza por las siguientes razones:

Primera, porque la jurisprudencia ha consagrado que el Tribunal superior, al que corresponda la apelación del asunto tramitado en el incidente del art. 103.5 LJCA, sí que puede anular un acto cuyo conocimiento en principio sería competencia de un Juzgado ${ }^{101}$.

98 Incluso puede suceder que la competencia corresponda a otro orden jurisdiccional. Véase la STS de 30 de septiembre de 2003 (casación 8614/1999; Ar. 8221) en un caso en que parte de las consecuencias de una sentencia contencioso-administrativa correspondían a la jurisdicción social.

99 La solución legal ha sido criticada por la doctrina. Así, por todos, MORILLO-VELARDE PÉREZ, J. I., "La ejecución de sentencias en el proceso contencioso administrativo", Revista del Poder fudicial, núm. 55 (1999), pp. 329-330; y SANTAMARÍA PASTOR, J. A., La Ley Reguladora de la furisdicción Contencioso-Administrativa, Iustel, 2010, p. 1095. Pero por mucho que disguste la solución legal es terminante y lege data no cabe sostener, como hace GEIS i CARRERAS, G. (2013: 174-182), que pese a ello los jueces competentes para la ejecución pueden siempre anular los actos incursos en la nulidad del art. 103.4 LJCA.

100 En ese sentido, CLAVERO ARÉVALO, M. (2003: 929).

101 La primera STS que lo reconoció fue la de 4 de febrero de 2004 (casación 1479/2002; Ar. 828). Después lo han reiterado otras como las de 9 y 17 de octubre de 2007 (casaciones 1451/2005 y 2218/2005; Ar. 7740 y 7324) y la de 5 de febrero de 2008 (casación 2027/2006; Ar. 458). Dice esta última que la declaración de si un determinado acto se ha hecho con la finalidad de eludir el cumplimiento de una sentencia "puede hacerse por la propia Sala sentenciadora aunque la competencia para conocer de un recurso contencioso-administrativo contra el nuevo acto corresponda a un Juzgado Contencioso-Administrativo, porque el art. 103.5 in fine debe ser interpretado en el sentido de que la competencia exigida es la propia del órgano o la que le es deferida en vía de recurso. Así, un Juzgado de lo Contencioso-Administrativo no podría en ejecución de sentencia declarar la nulidad de un Plan de urbanismo, pero una Sala de lo Contencioso-Administrativo sí podría declarar la nulidad de una licencia, puesto que la tendría en vía de apelación". 
Segunda, porque el Juzgado que no podría conocer vía art. 103.5 LJCA de la impugnación de un reglamento, sí que podría anular en esa misma vía los actos de aplicación de tal reglamento -actos que sí que entran en su competencia- basándose en la nulidad de ese reglamento ex art. 103.4. Sería una especie de recurso indirecto contra el reglamento con la doble singularidad de que el vicio del reglamento es el del art. 103.4 y de que se encauza en un incidente de ejecución del art. 103.5 LJCA. Si así ocurre, luego podrá anularse el reglamento mismo planteando una cuestión de ilegalidad o, sin ello, si el auto del Juzgado se apela y el Tribunal competente para resolver esa apelación lo es también para anular el reglamento. Volveremos después sobre esta posibilidad.

Y, tercera, porque al margen del art. 103.5 LJCA, la nulidad del art. 103.4 LJCA muchas veces podrá hacerse valer por las vías alternativas al art. 103.5 que luego se expondrán ${ }^{102}$.

Con todo esto, la limitación del último inciso del art. 103.5 se hace más liviana.

\section{3. ${ }_{\mathrm{c}}$ Es obligado o al menos posible el recurso administrativo previo?}

Claro es que si el incidente se insta contra un reglamento no será posible recurso administrativo previo pues nunca lo es (art. 112.3 LPAC). Habrá que acudir directamente al incidente del art. 103.5 LJCA. Si se trata de un acto que agote la vía administrativa no será necesario recurso de reposición pues está configurado como potestativo; la duda es si cabrá y si, por tanto, de interponerse, los plazos para promover el incidente quedarán a la espera de su resolución. Y si se trata de un acto que no pone fin a la vía administrativa se plantea si, antes de acudir al incidente del art. 103.5 LJCA, habrá que interponer recurso de alzada. Aunque nada diga el art. 103.5 y aunque la regla general es que antes de acudir a la jurisdicción contencioso-administrativa hay que agotar la vía administrativa, lo razonable es entender que en estos casos se exime de tal carga ${ }^{103}$; lo contrario sería una rémora donde la ley quiere que la jurisdicción sea expeditiva.

Pero, aun aceptándolo así, entiendo que es posible interponer previamente, según el acto cause o no estado en vía administrativa, recurso de reposición o de alzada

102 Por sólo citar ahora una sentencia reciente, lo explica así la STS 113/2019, de 4 de febrero (casación 3965/2017; Ar. 354): “... se mantiene el régimen de competencia establecido al efecto por la Ley y se establece la salvedad prevista en el último inciso del art. 103.5, de manera que la declaración se produce si el mismo órgano jurisdiccional competente para la ejecución lo es para conocer la legalidad del acto o disposición de que se trate $y$, en otro caso, habrá de acudirse a los procedimientos establecidos para su declaración por el órgano jurisdiccional competente al efecto...".

103 EZQUERRA HUERVA, A. (2014: 972). 
(una alzada que, por excepción, sería potestativa). Nada se opone a ello y, después de todo, si el interesado quiere dar a la Administración una oportunidad de rectificación y de evitar el conflicto judicial, bienvenida sea ${ }^{104}$.

\section{Plazo}

El incidente debe plantearse dentro de los plazos generales (dos meses) para la impugnación de los actos o reglamentos contados desde su notificación o publicación conforme al art. 46 LJCA $^{105}$. No hay ninguna razón para pensar que el plazo es otro $^{106}$. Menos todavía la hay para sostener que no haya plazo alguno ${ }^{107}$. Ahora bien, si se interpuso recurso de reposición o de alzada el plazo se contará desde la resolución de tales recursos de acuerdo a lo antes explicado. Y si el recurso no es resuelto cabrá en todo momento desde que se produzca el silencio negativo. Además, ante un reglamento supuestamente aprobado con la finalidad de eludir la sentencia, el plazo para una especie de recurso indirecto se reabrirá con cada acto de aplicación.

Más dudoso me parece el caso de los actos anteriores a la sentencia (o incluso de los posteriores a ella pero anteriores a su firmeza) que se dictaron presagiando su resultado adverso y con la finalidad de eludirlo y que, como ya se vio más arriba, pueden estar aquejados de la nulidad del art. 103.4 LJCA: antes de que la sentencia haya devenido firme no se pueden recurrir por el motivo del art. 103.4, según se razonó antes; y después de que la sentencia sea firme ya habrán pasado los dos me-

104 La respuesta dada me parece segura si se trata de actos dictados en el normal ejercicio de potestades administrativas. Si, por el contrario, se trata de los específicos actos producidos en ejecución voluntaria de la sentencia -actos de los que, como vimos, se ha negado incluso su naturaleza de actos administrativos- la solución es más dudosa. Aun así, sin perjuicio de que desde luego quepa acudir directamente al incidente del art. 103.5 LJCA, no veo impedimento a que el particular opte por un recurso administrativo previo y que, en tal caso, el plazo para promover el incidente se cuente desde su resolución.

105 En esa línea, aunque con poca explicación, la larga STS de 27 de mayo de 2008 (casación 2648/2006; Ar. 3494), en su fundamento $6^{\circ}$, cuando invoca el plazo de dos meses del art. 46.1 LJCA para desestimar en ejecución la pretensión de nulidad de una norma ejercida a los cuatro meses de su publicación.

106 En concreto, nada tiene que ver aquí el plazo de cumplimiento voluntario de sentencias ni el plazo de prescripción de la acción para instar la ejecución forzosa, pues no se trata de nada de eso. En realidad, si se trata de una sentencia merodeclarativa ni siquiera hay plazo para su cumplimiento puesto que, por su naturaleza, no exige cumplimiento. Ni siquiera parece que sea óbice el que ya conste la total ejecución de la sentencia (pese al art. 109.1 LJCA) pues puede que después de eso surja el acto o reglamento contrario a la sentencia con el fin de eludir sus efectos. En esa línea apunta la STS 1606/2017, de 25 de octubre (casación 2576/2016; Ar. 4547): la Administración alegó que "la sentencia de cuya ejecución se trata ya fue ejecutada"; pero pese a ello, el TS consideró que un reglamento muy posterior estaba incurso en la nulidad del art. 103.4 y lo anuló en el incidente del 103.5 LJCA.

107 En contra, SANTAMARÍA PASTOR, J. A. (2010: 1096), dice que el silencio de la norma es "indicio seguro de la inexistencia de plazo". No lo creo de ninguna forma: no hay razón para excluir la aplicación de los plazos generales y lo contrario generaría perpetua inseguridad. 
ses contados desde la notificación o publicación del acto o reglamento. Para evitar ese absurdo lo razonable es entender que en estos casos el plazo de dos meses para plantear el incidente del art. 103.5 LJCA se abre con la firmeza de la sentencia que se pretendía burlar. La doctrina de la actio nata (art. 1969 CG) lo justifica. Aun así, no hay bases sólidas en la LJCA para aceptar esta excepción a la regla general y no he encontrado sentencias que acojan la tesis defendida. Añadamos sólo que, incluso aunque no se aceptara esta excepción propuesta, ello no haría inocua esta causa de nulidad de los actos anteriores a la sentencia que podría canalizarse instando una revisión de oficio del art. 106 LPAC o como base para otras pretensiones en diferentes incidentes de ejecución, como luego se verá.

\section{Legitimación}

El órgano judicial encargado de la ejecución puede declarar la nulidad por esta vía "a instancia de parte". No cabe, pues, de oficio ${ }^{108}$. Pero el art. 109.1 LJCA, que los tribunales entienden de aplicación, confiere una amplia legitimación que va mucho más allá de quien fue demandante victorioso: la pueden instar, además de todos los que hayan sido parte en el proceso ${ }^{109}$, cualesquiera "personas afectadas" aunque no hayan sido ni hayan podido ser parte del proceso en el que recayó la sentencia ${ }^{110}$.

108 Lo confirma la STS de 31 de enero de 2006 (casación 8263/2003; Ar. 4356) y la STS 1955/2016, de 21 de julio (casación 3916/2015; Ar. 3916) remata: "Tal procedimiento es a instancia de parte (...) sin que sea dable declarar de oficio la nulidad radical de los actos o disposiciones que (...) se encuentren en la situación descrita en el art. 103.4 LJCA”. Cosa distinta es que la nulidad del art. 103.4 LJCA sí pueda, quizá, ser apreciada de oficio como excepción frente a otra pretensión, como la que suscite la Administración para que se declare la imposibilidad de ejecución.

109 Según la STS 70/2017, de 20 de enero (casación 2511/2015; Ar. 1014) quienes fueron parte en el proceso están legitimados aunque ya no sean personas afectadas. En el caso, la parte había vendido sus participaciones. Es esto expresión de la regla general de la perpetuatio legitimationis aunque llevada un poco más allá de su ámbito prototípico, que es el de un mismo proceso, al proceso de ejecución subsiguiente. Véase, no obstante, CARBONELL PORRAS, E., "La pérdida sobrevenida de legitimación. Revisión de la doctrina de la perpetuatio legitimationis (a propósito de la sentencia de la Sala de lo Contencioso-administrativo del Tribunal Supremo de 30 de mayo de 2011)", en GARCÍA DE ENTERRÍA, E. y ALONSO GARCÍA, R. (Coords.), Administración y justicia, Un análisis jurisprudencial. Liber amicorum Tomás-Ramón Fernández, Civitas, 2012, I, pp. 867 y ss., publicado también en REDA, nº 153 (2012).

110 Se concluye así poniendo en relación el art. 103.5 con los arts. 104.2 y 109.1 LJCA. Es hito en esta interpretación la STS de 7 de junio de 2005 (casación 2492/2003; Ar. 5244), que luego ha sido seguida por otras muchas. Así STS de 31 de enero de 2006 (casación 8263/2003; Ar. 4356): "El hecho de que este artículo 103.5 se refiera, exclusivamente, a la «parte» para solicitar la nulidad de los actos dictados con posterioridad a la sentencia contrarios a los pronunciamientos de la misma, parece que no impediría que tal solicitud pudiera ser formulada por las «personas afectadas», a las que se refiere tanto el artículo 104.2, para poder instar la ejecución forzosa de la sentencia, como el 109.1 - al que el 103 se remite (si bien solo en sus apartados 2 y 3 )-que regula la legitimación en el procedimiento incidental por el que habría de discurrir la petición de nulidad". Igualmente, SSTS de 1 y 28 de marzo de 2006 (casaciones ... 8466/2002; Ar. 2070 y 3138), y de 6 de abril de 2011 (casación 1602/2007; Ar. 2962). Pero sí que se exige una verdadera 
Más todavía: se admite que la acción popular consagrada en algunos sectores (señaladamente en urbanismo) permite instar la ejecución -y, por tanto, también este incidente- de manera que cualquier sujeto puede promoverlo ${ }^{111}$. Incluso estos terceros pueden instar el incidente en contra de la voluntad de quien venció en juicio ${ }^{112}$.

afectación por la sentencia de cuya ejecución se trate como ya razonó el ATS de 22 de junio de 2005 (recurso 533/1994) y ejemplificó más recientemente la STS 2036/2017, de 20 de diciembre (casación 3105/2016; Ar. 6028): el primero, ante una sentencia sobre concentración de empresas dedicadas a la radiodifusión, negó legitimación a una empresa que no tenía más relación con el asunto que el dedicarse al mismo sector; y la segunda rechaza la legitimación de unos colindantes que no probaron ningún derecho afectado. Incluso se afirma que la legitimación para instar la ejecución no coincide con la legitimación que pudo haber para impugnar el acto originario pues una cosa es que le afectase éste y otra cosa que le afecte la sentencia. Interesante es también la STS de 20 de octubre de 2011 (casación 522/2009; Ar. 1317 de 2012): “... la determinación de quién tiene la consideración de «personas afectadas» por el fallo de una sentencia debe analizarse caso por caso, atendiendo a los propios términos en que esté redactado el fallo de la sentencia y a la posición en que se encuentren frente a ese fallo...; pero es en todo caso la condición de afectado por la sentencia la clave de la posible legitimación para intervenir en la ejecución”. En el caso que se planteaba, dice el TS, el fallo "no deja duda del carácter perfectamente singularizado de su mandato respecto de los recurrentes" que eran determinados participantes en un concurso, no los demás que también participaron; estos tendrán que poner "recursos diferenciados en los que conseguir fallos de sentido similar al que se toma como referencia", aunque se sirvan en su fundamentación jurídica de la sentencia anterior referida otras personas. Ahora bien, personas afectadas por la sentencia no son sólo personas afectadas por la cosa juzgada de la sentencia, pese a que así lo mantuvo la STS de 12 de febrero de 1993 (apelación 11727/1990, Ar. 975) y así lo afirma HUERTA GARICANO, I. (2000: 108).

111 STS de 23 de abril de 2010 (casación 3648/2008; Ar. 4711): admite que una asociación que no había sido parte en el proceso originario inste la ejecución de sentencia en ejercicio de la acción popular. Igualmente, STS de 26 de enero de 2005 (casación 6867/2001). Podría haberse mantenido que, como la ejecución sólo la pueden instar las "personas afectadas", la acción popular no sería suficiente. En ese sentido, aunque obiter dicta, ATS de 22 de junio de 2005 (recurso 533/1994). Véase CLAVERO ARÉVALO, M. (2003: 928-929).

112 Es así porque no está en manos de las partes determinar los efectos de las sentencias, por ejemplo, mediante convenios que no tendrán valor frente a terceros. Lo demuestra la STS de 2 de marzo de 2015 (casación 3160/2013; Ar. 1782): "La declaración de nulidad (...) no puede depender ni desaparecer por el simple hecho de que la parte que ha obtenido sentencia favorable no formule alegaciones o entienda que la sentencia está ejecutada (...) Tal declaración de nulidad trasciende de la actuación procesal de las partes... ". En el mismo sentido STS de 3 de marzo de 2015, casación 4063/2013; Ar. 1951. También es interesante la STS de 16 de abril de 2009 (casación 2826/2007; Ar. 5271): ante una supuesta transacción y obligación de desistimiento frente a la ejecución, dice que "aun en el supuesto de que se hubiese materializado procesalmente el desistimiento mencionado, no por ello el mismo tendría que ser aceptado, por cuanto, como dispone el artículo 74.4 LJCA, «el Juez o Tribunal (...) podrá rechazarlo razonadamente cuando apreciare daño para el interés público». Y, no conviene olvidar que nos movemos, en el supuesto de autos, en el ámbito de una infracción urbanística en el que, por tanto, están en juego unos intereses generales indisponibles por el simple acuerdo entre las partes sobre la base de una satisfacción económica". Asimismo dice la STS de 16 de mayo de 2014 (casación 1621/2013; Ar. 3867, repetida en Ar. 4354) ante la eventualidad de que, en ejecución de sentencia, el demandante estuviera dispuesto a aceptar una indemnización en vez de la ejecución en sus propios términos: “... el cumplimiento de la legalidad urbanística ni está sometido a la disponibilidad de las partes ni puede, por eso mismo, ser objeto de transacción”. Ya antes dijo la STS de 5 de abril de 2001 (casación 3655/1996; Ar. 3030) que hay "un esencial interés público (...) que demanda que se cumplan las sentencias de los Tribunales y que se cumplan en sus propios términos y no en los 
La legitimación pasiva la tiene la Administración que fue parte demandada en el proceso principal y que ha dictado el acto o disposición que ahora se ataca. No creo que pueda tenerla otra Administración. Antes no excluimos la posibilidad de que actos o disposiciones de una Administración distinta pudieran incurrir en la nulidad del art. 103.4 LJCA. Pero incluso aunque se acepte esa posibilidad, sería una nulidad sólo alegable en alguna otra de las vías que luego estudiaremos, no en la del art. 103.5 LJCA ${ }^{113}$. También hay que reconocer legitimación pasiva a todos cuyos derechos o intereses legítimos puedan quedar afectados por la anulación del acto o disposición impugnados por esta vía, aunque no hubieran sido parte en el proceso originario: la regla general del art. 21.b) LJCA debe tener aquí aplicación para evitar indefensión.

\section{Objeto: actuaciones impugnables y pretensiones}

Las actuaciones impugnables por esta vía son las que hemos dicho que pueden incurrir en la nulidad del art. 103.4 LJCA. Pero no todas, como ya sabemos; por ejemplo, no aquéllas que escapan de la competencia del Juzgado o Tribunal de la ejecución, no las que provienen de una Administración distinta de la demandada en el proceso principal.

Tratándose de actos, puede atacarse por esta vía el originario o el resolutorio del recurso administrativo que contra él potestativamente se hubiera interpuesto (o el silencio negativo). Cabe impugnar simultáneamente un acto y un reglamento a los

que decidan los particulares según sus conveniencias...”. Por su parte la STC 219/1994, de 18 de junio, consideró que ni siquiera la conveniencia del ejecutante o de aquél que venció en juicio y en cuyo favor se declaró un derecho es causa suficiente para alterar lo decidido en la sentencia. Se aparta de esta línea la sorprendente STS de 21 de junio de 2005 (casación 4936/2002; Ar. 8968) que desestimó la nulidad del art. 103.4 LJCA instada por un tercero ante el hecho de que la demandante (Administración del Estado) en el proceso principal, manifestó que su interés había quedado satisfecho.

Pero, dicho eso, sí que están a disposición de las partes que recurrieron sus propios derechos, tanto los que expresamente les reconozca la sentencia como los que puedan derivarse indirectamente de ella. Y a este respecto sí que son posibles convenios de validez y eficacia incuestionables frente a los que lo suscribieron. Incluso es posible la renuncia de derechos de los particulares dentro de los límites generales establecidos (arts. 6.2 CG y 84.1 LPAC) y la transacción propiamente dicha con la finalidad de evitar el proceso de ejecución o de terminar el ya iniciado.

113 La STS de 28 de marzo de 2006 (casación 8466/2002; Ar. 3138) utiliza como argumento para no aplicar el art. 103.4 y 5 LJCA, entre otros, que el acto previamente anulado provenía del Ayuntamiento y el luego combatido por este cauce era de la Administración autonómica. Y la STS de 12 de marzo de 1996 (casación 5554/1993; Ar. 2558) afirmó que “... la ejecución (voluntaria) de sentencias contencioso-administrativas corresponde a la Administración autora del acto recurrido (...) por lo que la petición de ejecución dirigida a otra (...) subvertiría la estructura de la ejecutoria...". Quizá, sin embargo, la solución podría ser otra en el caso, ya antes aludido, de que se trate de una Administración matriz y de un ente instrumental suyo: tal vez ese supuesto merezca el mismo tratamiento que corresponde a actuaciones contrarias a una sentencia y con el ánimo de eludirla producidas por diversos órganos de una misma Administración. 
que se imputa la nulidad del art. 103.4 LJCA. Y asimismo cabe la impugnación sólo de un acto pero fundada en que el reglamento que aplica es nulo conforme al art. 103.4 LJCA. O sea, que, como ya apuntamos antes, cabe dentro del incidente del art. 103.5 un recurso indirecto contra reglamentos ${ }^{114}$; recurso indirecto que, caso de prosperar, llevará a declarar la nulidad del acto pero que también podrá dar lugar a la corta o a la larga, de acuerdo a las reglas generales que lo rigen, a la declaración de nulidad del reglamento mismo ${ }^{115}$. Esto tiene gran relevancia práctica cuando lo incurso en la nulidad del art. 103.4 son, como ha sido frecuente, planes de urbanismo. Además, palia en parte, como ya dijimos, la limitación competencial impuesta por el art. 103.5 in fine.

La pretensión que se ejerce como mínimo será siempre una pretensión anulatoria; para ser exactos, de declaración de una nulidad de pleno derecho que, además, según sabemos, ha de basarse exclusivamente en el art. 103.4 LJCA. Pero ¿es posible pedir y acordar algo más?; en concreto, ¿cabe pretender el reconocimiento de derechos y la condena a la Administración a realizar algo? Una interpretación puramente literal inclina a responder negativamente ${ }^{116}$. Ocasionalmente el TS ha seguido esa interpretación ${ }^{117}$. Pese a ello, parece obligada una respuesta positiva.

114 La cuestión, en principio, era dudosa. Véase REBOLLO PUIG, M., "Recursos contra reglamentos y cuestión de ilegalidad", fusticia Administrativa, no extraordinario dedicado a la Ley de la Jurisdicción Contencioso-Administrativa (1999), p. 40. Pero finalmente entiendo que hay que aceptar esta posibilidad que, además, parecen admitir los tribunales. Ejemplo de ello se vislumbra en la STS de 29 de mayo de 2015 (casación 3301/2014; Ar. 3155): una sentencia (de 1994 confirmada por TS en 2000) anuló una licencia. Pero luego se modificó el PGOU (en 2008) y se otorgó nueva licencia (en 2012). Frente a esta última licencia recurrieron los particulares invocando el art. 103.4 LJCA. El TSJ lo rechazó porque no impugnaron la reforma del PGOU. Pero el TS estima la casación y dice que la Sala debe resolver el incidente planteado al amparo del 103.4 LJCA. Al hacerlo deberán enjuiciar la segunda licencia e indirectamente la reforma del PGOU para ver si esta reforma y aquélla licencia están incursas en la causa de nulidad del art. 103.4 LJCA.

115 A la corta si el juez o tribunal competente para anular el acto lo es también para anular el reglamento. Incluso aunque no lo sea en primera instancia pero sí en apelación. A la larga si no es competente para anular el reglamento, supuesto en el que, tras la firmeza de la sentencia anulatoria del acto, deberá suscitar cuestión de ilegalidad. Esto resulta de los arts. 26, 27 y 123 a 126 LJCA sin que haya ningún impedimento, sino todo lo contrario, para que encuentren aplicación en el marco del incidente del art. 103.5 LJCA.

116 El art. 103.5 LJCA dice que el tribunal "declarará (...) la nulidad de los actos y disposiciones" y nada más. Acaso refuerce este argumento la comparación de este art. 103.5 con el art. 108.2 LJCA que sí menciona los daños y perjuicios causados: si en éste se dice y en aquél no, es que en aquél no cabe. Aunque el argumento también se puede volver en contra: puesto que el art. 108.2 prevé expresamente que se determinen los daños y perjuicios (y que se condene, hay que suponer, a indemnizarlos), lo lógico es que el art. 103.5 permita también esto.

117 Así en la STS de 15 de diciembre de 2010 (casación 3699/2008; Ar. 3350): en el incidente del 103.5 anuló un plan especial conforme al art. 103.4 LJCA. Pero el ejecutante pedía también la demolición de "la parte de la edificación ilegal e ilegalizable". Y esta STS lo deniega con este razonamiento: “... no cabe hacer el pronunciamiento que pretende el recurrente en orden al derribo de la parte de la edificación 
Porque si en este incidente se anulan actos (por ejemplo, órdenes de pago, licencias de obras) y esos actos han dado lugar a cambios (por ejemplo, ingresos en favor de la Administración, construcción de edificios), remitir el restablecimiento material de la realidad alterada a otro incidente resulta una complicación infundada y superflua. Forzoso es reconocer que la admisión de pretensiones de condena parecerá extraña cuando la sentencia originaria (la que se considera incumplida) se limitó a anular un acto o un reglamento. Pero por extraño que resulte a eso conduce el art. 103.5 LJCA. También hay que reconocer que eso puede llevar a ejecuciones con muchas derivaciones; incluso es imaginable que ahora se suscite la imposibilidad de ejecución por causa material o legal: no imposibilidad de ejecutar en sí misma la sentencia originaria, sino imposibilidad de ejecutar las resoluciones judiciales de condena que en su ejecución, vía art. 103.5 LJCA, se dicten ${ }^{118}$. Pero, pese a lo rocambolesco que resulte, a eso debe conducir el art. 103.5 LJCA para no desactivar sus virtualidades. Con lo expuesto no es de extrañar que las ejecuciones de algunas sentencias (sobre todo de las anulatorias de reglamentos o planes), encauzadas por el art. 103.5 LJCA, acaben por tener una complejidad extraordinaria que, además, los eterniza. Es el precio por la construcción acogida del derecho a la tutela judicial efectiva en su proyección sobre el derecho a la ejecución de sentencias, aunque a la larga sea dudoso si un sistema tan abigarrado sirve bien a ese fin o es un suplicio para todos.

\section{OTROS GAUCES PARA INVOGAR Y ESTIMAR ESTA CAUSA DE NULIDAD}

El art. 103.5 LJCA establece específicamente que la causa de nulidad del apartado anterior puede declararse en ejecución de la sentencia presuntamente burlada. Pero eso no significa que ésa sea siempre la única vía en la que es posible alegar con éxito la causa de nulidad del art. 103.4 LJCA $^{119}$. Hay otras vías posibles en muchos

ilegal e ilegalizable, pues en el incidente de nulidad promovido al amparo de lo previsto en el artículo 103.4 LJCA (...) hemos de limitarnos a declarar la nulidad de aquellos actos o disposiciones que son contrarios a lo resuelto en la sentencia y que consideramos dictados para eludir el cumplimiento de aquélla. La decisión acerca de las demás cuestiones e incidencias que se susciten en relación con el cumplimiento de la sentencia, en particular las relativas a la demolición de la parte edificada que no resulte legalizable, son ajenas a este incidente de nulidad y habrán de adoptarse en (otro) incidente de ejecución de la sentencia”.

118 De hecho, esa imposibilidad se ha declarado en algunos casos. Muestra de ello es la STS 70/2017, de 20 de enero (casación 2511/2015; Ar. 1014). BAÑO LEÓN, J. M. (2016: 90) dice, que "la sentencia que (meramente) declara la anulación ni se ejecuta ni es nunca imposible su ejecución; será en todo caso imposible la remoción de efectos". Pero, a la postre, cabe que una sentencia merodeclarativa lleve, vía art. 103.5 LJCA, a una declaración de imposibilidad de ejecución de lo decidido en ese incidente.

119 En contra, afirman que sólo es posible alegar la causa de nulidad del art. 103.4 LJCA en el incidente del art. 103.5 CHINCHILLA PEINADO, J. A. (2008: 90-91) y GEIS i CARRERAS, G. (2013: 156). Inducen a ese error algunas sentencias a las que nos referimos después y que son correctas pero sólo referidas a ese género de actos dictados precisamente para el cumplimiento de un fallo. Hay además 
casos, aunque no en todos. Es más, a veces no cabe la del art. 103.5 LJCA (cuando el acto o disposición impugnados escapan de la competencia del juez de la ejecución o cuando provienen de Administración distinta de la demandada en el proceso originario) y sí otras en las que alegar y declarar esta nulidad. Veámoslas.

\section{Recurso contencioso-administrativo ordinario y autónomo}

\section{A)Naturaleza}

Un recurso contencioso-administrativo autónomo (esto es, interpuesto al margen de los trámites de ejecución de la sentencia anterior) puede basarse en el art. 103.4 LJCA y ser estimado por esa razón. En estos procesos autónomos la sentencia previa y supuestamente burlada no juega como título de ejecución. Simplemente en la demanda será una premisa de la pretensión; y en la sentencia una parte del silogismo judicial. Ahora bien, en todo caso como una premisa incontestable en virtud de la cosa juzgada material que se desplegará aquí en su vertiente positiva o prejudicial. Con esa singularidad -que es pequeña singularidad- se tratará de un proceso contencioso- administrativo ordinario, y eso marca y preside todo su régimen.

algunas que confusamente extienden esa solución. Es el caso, al menos, de estas dos SSTS: la de 23 de diciembre de 2010 (casación 2970/2006; Ar. 1033 de 2011) y la STS 1996/2016, de 6 de septiembre (casación 1215/2015; Ar. 4817). La primera, la de 2010, dice literalmente que "sólo el juez o tribunal a quien corresponde la ejecución de la sentencia es competente para resolver cuantas cuestiones se puedan suscitar en relación con la misma, por lo que resulta inadmisible la acción ejercitada contra dicho acuerdo al margen del proceso de ejecución"; pero la misma sentencia dice luego lo contrario: "No resulta excluyente la propia actitud procesal del demandante al no suscitar incidente en ejecución de sentencia sino interponer directamente recurso contencioso-administrativo contra la Revisión del Plan General pues, como hemos señalado (sic!), tal pretensión puede apoyarse al amparo del art. 103.4 LJCA por considerar que el cambio de uso lo fue con el único fin de eludir la ejecución de la sentencia, o en proceso independiente". La segunda, la de 2016, afirma, como si fuera jurisprudencia ya asentada, que "las cuestiones suscitadas con motivo de la ejecución de sentencia no deben resolverse en un recurso contencioso administrativo independiente, no siendo admisible utilizar el recurso contencioso-administrativo para cuestionar actuaciones administrativas posteriores a las que se achaca la finalidad de impedir la ejecución de la sentencia, pues tal pretensión deberá articularse en el trámite de ejecución de sentencia, dado que el órgano jurisdiccional competente para la ejecución de la sentencia lo es también para resolver todas las cuestiones que se planteen en su ejercicio"; sin embargo, esta idea, además de no reflejar realmente la jurisprudencia, aparece obiter dicta y no es aplicada por esa sentencia que en ningún momento se plantea inadmitir el recurso que no se había suscitado en incidente de ejecución. En suma, la idea según la cual el art. 103.4 sólo se puede invocar en el incidente del art. 103.5 LJCA expresa una verdad a medias: sólo es acertada para una parte de las actuaciones incursas en la nulidad del art. 103.4 LJCA (sólo cuando se trata de actuaciones formalmente realizadas para cumplir el fallo) y sólo para excluir algunas vías (la del recurso contencioso-administrativo autónomo), no todas (no la revisión de oficio). 
B) Supuestos en los que no es posible y en los que sí lo es, ya sea sin la alternativa del artículo 103.5 LFCA o ya sea como alternativa a esa vía

Según la jurisprudencia, este cauce del proceso autónomo para invocar el art. 103.4 LJCA sólo cabe respecto a las actuaciones realizadas en el ejercicio ordinario de potestades administrativas ${ }^{120}$, no contra las que se produzcan formalmente para cumplir la sentencia; o sea, no contra las que se presenten como debidas u obligadas directamente por la sentencia. Estas otras sí que deben ser combatidas en ejecución de sentencia. Lo contrario supondría sacar de la ejecución lo que es exclusivo de ella y con frecuencia hurtar al juez de la ejecución su competencia en favor de otro juez. Además, comportaría dar trato de verdaderos y propios actos administrativos a los que, según tesis dominante, en el fondo no lo son ${ }^{121}$. La STS de 15 de enero de 1999 (casación 30/1995; Ar. 349; nótese, sentencia incluso anterior a la actual LJCA) era ya explícita:

"... el auto de inadmisión razona que (el acto municipal) no resulta impugnable, por tratarse de una mera ejecución de lo ordenado en una sentencia firme, sin que quepa un recurso contencioso-administrativo nuevo sobre una materia juzgada (...). Este razonamiento concuerda plenamente con la doctrina expresada por esta Sala en reiteradas ocasiones. Sin entrar en el debate de cuál sea su auténtico carácter -administrativo, procesal o de naturaleza jurídica intermedia entre lo administrativo y lo procesal- es claro que los actos dictados en el proceso de ejecución de una sentencia firme deben ser combatidos en el trámite incidental correspondiente del proceso en que se dictó la sentencia que mediante ellos se ejecuta, deduciendo las peticiones adecuadas ante el órgano jurisdiccional que conoce y resuelve

120 Por ejemplo, tras la anulación judicial de un plan, la Administración aprueba un nuevo plan. Esto no se hace en cumplimiento de la sentencia. Ésta no impone que se apruebe un nuevo plan en sustitución del anulado. Simplemente comporta que vuelve a estar vigente el plan que el anulado pretendió derogar. Si la Administración quiere sustituir al plan redivivo lo hará en ejercicio de una potestad, la de planeamiento, completamente al margen de su obligación de cumplir la sentencia. Por ese ese nuevo plan podrá ser objeto de un proceso contencioso-administrativo autónomo incluso para alegar su nulidad basada en el art. 103.4 LJCA.

121 Éste es el fundamento teórico y último de esta regla que sólo permite en el enjuiciamiento judicial de estos actos en ejecución de sentencia. Lo ha explicado BAÑO LEÓN, J. M. (2016: 87, 92 y 96). Antes citamos estas mismas páginas para afirmar que esos actos de la Administración producidos para el cumplimiento de sentencias no son exactamente actos administrativos pues no se dictan en ejercicio de potestades administrativas atribuidas por el ordenamiento para la consecución del interés general. Pero BAÑO lo afirma para explicar de inmediato que "en consecuencia, esos actos no deben ser objeto de impugnación autónoma, sino en todo caso objeto de examen en el incidente de ejecución" y "por el juez de la ejecución”. Hasta el punto de considerar "patentemente ilegal la práctica reiterada de las Administraciones públicas de dictar estos actos con pie de recurso". 
de la ejecución. No resulta admisible por ello la interposición de recursos contencioso-administrativos sucesivos frente a tales actos..."122.

Por sólo citar una STS más reciente, es ilustrativa la 90/2018, de 25 de enero (casación 3/2017; Ar. 254): una vez que el tribunal había determinado exactamente lo que un Ayuntamiento debía hacer para cumplir una sentencia, inadmite un recurso autónomo para discutir lo que ese Ayuntamiento había hecho para esa ejecución: “... el acuerdo dictado por el Ayuntamiento (...) en ejecución de sentencia debió haber sido impugnado por la recurrente en el seno del incidente de ejecución de sentencia por cuanto (...) lo que ha hecho es cumplir su deber legal de ejecutar la sentencia, no estando permitida una impugnación autónoma...".

Pero si se trata de impugnar actos o reglamentos dictados en ejercicio de las potestades ordinarias de la Administración (no, pues, en cumplimiento de la sentencia) con fundamento en el art. 103.4 LJCA, ésta vía del recurso contencioso-administrativo autónomo está abierta como admite paladinamente el TS. Es representativa la STS de 20 de marzo de 2014 (casación 4333/2011; Ar. 2414). Frente a la alegación de que el art. 103.4 no podía invocarse en un recurso autónomo sino sólo en la vía incidental de ejecución prevista en el art. 103.5 LJCA, dice:

“....sin perjuicio de que en efecto pudo dicha cuestión haberse hecho valer por la vía indicada, tampoco nuestra Ley impide entablar un recurso contencioso-administrativo autónomo y la consiguiente formación de un nuevo litigio, por lo que no impone la vía antes señalada de los artículos 103 y siguientes de manera necesaria" ${ }^{\prime 23}$.

No sólo sí que es posible sino que antes era la única vía y ahora, cuando ya se admite la del incidente de ejecución, sigue siendo cauce natural y normal.

122 Cita otras sentencias anteriores a la LJCA de 1998 TOLOSA TRIBIÑO, C. (2006: 178-179). Y J. FERNÁNDEZ HERNANDO, J. "El incumplimiento de la sentencia administrativa, sus formas y su tratamiento jurisprudencial", en Libro homenaje al profesor Fordana de Pozas, Vol. I, Instituto de Estudios Políticos, 1961, Tomo III, Vol. 1º, pp. 248 a 253 y FERNÁNDEZ, T. R. (1974: 161), se remontan a las SSTS de 17 de mayo de 1943, 9 de noviembre de 1944 y 20 de noviembre de 1949. Véase también la STS de 10 de noviembre de 2006 (casación 4020/2003; Ar. 10074).

123 En idéntico sentido, entre otras, SSTS de 5 de febrero de 2008 (casación 2027/2006; Ar. 458); 29 de septiembre de 2009 (casación 2827/2005; Ar. 325 de 2010); 18 de noviembre de 2011 (casación 5883/2008; Ar. 2297 de 2012); 8 de febrero de 2013 (casación 2134/2012; Ar. 1382); 19 de febrero de 2013 (casación 5525/2010; Ar. 3195); 892/2016, de 25 de abril (casación 290/2015; Ar. 1858); y 2481/2016, de 21 de noviembre (casación 3207/2015; Ar. 6582). Por sólo transcribir un pasaje de alguna, se lee en la de 18 de noviembre de 2011: “... no es cierto que la existencia de una anterior sentencia anulatoria de un Plan General excluya de manera absoluta la posibilidad de que el nuevo plan aprobado sea objeto de impugnación en un proceso autónomo. Ciertamente, la nulidad del nuevo Plan podrá pedirse como incidente de ejecución de la anterior sentencia, al amparo de lo previsto en los apartados 4 y 5 del art. 103 LJCA; pero también en un proceso autónomo, siendo esto último lo procedente cuando se aducen otras causas de nulidad además de la referida al intento de eludir la anterior sentencia". 
Hay más. En algunos casos no es sólo que el proceso autónomo sea posible para hacer valer la nulidad del art. 103.4 LJCA sino que no tendrá la alternativa del cauce del art. 103.5 LJCA. Ya explicamos que a veces éste no cabe (cuando el juez de la ejecución no es competente o cuando se trata de combatir actos o reglamentos de Administración distinta de la demandada). En tales hipótesis el proceso contencioso-administrativo autónomo será la vía por antonomasia para alegar la nulidad fundamentada en el art. 103.4 LJCA $^{124}$.

Por tanto, hay supuestos en los que no es posible esta vía (si se trata de impugnar actos debidos para el cumplimiento de la sentencia); y hay otros en los que no cabe la del art. 103.5 LJCA sino sólo esta otra del proceso autónomo. Pero salvo esas excepciones, el interesado tiene opción para seguir un cauce u otro ${ }^{125}$. Lo que no podrá hacer es seguir las dos vías, ni simultánea ni sucesivamente, ambas basadas en el art. 103.4 LJCA ${ }^{126}$; sí podrá seguirlas simultánea o sucesivamente si la del proceso autónomo la fundamenta en un vicio distinto del previsto en el art. 103.4.

124 Es clara, entre otras, la STS de 6 de abril de 2011 (casación 1602/2007; Ar. 2962): el art. 103.5 LJCA "no resuelve el supuesto de la carencia de competencia jurisdiccional... No obstante lo más razonable en estos casos sería el ejercicio de esta acción -basada en el art. 103.4 LJCA y no en el incumplimiento de la legalidad ordinaria- como recurso contencioso-administrativo independiente y autónomo ante el órgano jurisdiccional competente...". Buen ejemplo suministra la STS de 16 de diciembre de 2011 (casación 171/2008; Ar. 2830 de 2012). En recurso autónomo se había ejercicio contra un plan especial la acción del art. 103.4 LJCA por entender que el plan quería vulnerar la sentencia de un Juzgado anulatoria de una licencia; y dice: "El ejercicio de esta acción prevista en el art. 103.4 LJCA, que normalmente encuentra su cauce adecuado como un incidente en la ejecución de sentencia, resulta adecuada (en un recurso autónomo) en el caso examinado porque el órgano judicial al que corresponde la ejecución de la sentencia -un Juzgado de lo contencioso-administrativo- carece de competencia para declarar la nulidad de un plan especial -que corresponde ex art. 10.1.b) a la Sala de este orden jurisdiccional de los Tribunales Superiores de Justicia-. De manera que estamos ante el supuesto que contempla el art. 103.5, inciso final, LJCA, pues el juez al que corresponde la ejecución de la sentencia que declaró la nulidad de la licencia no tiene atribuida competencia, ex art. 8 LJCA, para declarar la nulidad del plan especial". Defiende esta vía XIOL RÍOS, J. A. (2016: 724): “... deberá interponerse recurso contencioso-administrativo independiente...”. Asimismo GALÁN GALÁN, A. (2006: 154-155).

125 SSTS de 6 de abril de 2011 (casación 1602/2007; Ar. 2962) y de 8 de febrero de 2013 (casación 2134/2012; Ar. 1382). Ya FERNÁNDEZ, T. R. (1974: 164-165), tras referirse a la STS de 16 de diciembre de 1971, que admitió tanto la vía del incidente de ejecución como la del recurso autónomo, dice: “... quien elige la acción que se ejercita es el propio interesado y (...) no es incompatible el montaje de un incidente de ejecución y de un nuevo proceso contencioso-administrativo...”.

126 A este respecto hay sentencias aparentemente contradictorias. La STS de 28 de septiembre de 2012 (casación 1009/2011; Ar. 9762) dice: "Ninguna objeción ponemos en este caso (...) en orden al doble cauce procesal seguido, es decir, acudir en fase de ejecución de sentencia ejerciendo la acción prevista en el art. 103.4 LJCA y, a su vez, ejercitando la impugnación ordinaria contra cualquier acto o disposición general”. Asimismo la STS 892/2016, de 25 de abril (casación 290/2015) afirma que ambas vías son compatibles. Por el contrario, en la STS de 5 de febrero de 2008 (casación 2027/2006; Ar. 458) se lee: “... en tales casos o se interpone un recurso contencioso-administrativo independiente contra el nuevo acto de la Administración o se pide su anulación en incidente de ejecución. Lo que no se puede hacer es pedir las dos 


\section{C) Agotamiento de la vía administrativa}

Como cualquier contencioso-administrativo, habrá que haber agotado antes la vía administrativa de modo que si el acto no causaba estado será necesario previa alzada. Y si el acto ya ponía fin a la vía administrativa será potestativa la reposición. En el caso de reglamentos, como nunca son susceptibles de recurso administrativo (art. 112.3 LPAC), habrá que interponer sin más el contencioso. Todo ello sin ninguna especialidad porque, a fin de cuentas, nos encontraremos ante un recurso ordinario sin más singularidad que su fundamento en la causa de nulidad del art. 103.4 LJCA y el hecho de partir de una sentencia con valor de cosa juzgada material.

\section{D) Plazo}

Este proceso sólo cabrá mientras no hayan transcurrido los plazos ordinarios para recurrir ${ }^{127}$. Si ya han pasado no cabrá este recurso ni siquiera con la invocación del art. 103.4 LJCA. Si se trata de actos, pasados dos meses desde la notificación, habrán devenido firmes e irrecurribles ${ }^{128}$. Si lo impugnado es un reglamento, sólo cabrá el recurso directo basado en el art. 103.4 durante dos meses contados desde su publicación; pero, como siempre, sí será posible recurrir cada uno de sus actos de aplicación fundándose en la nulidad del reglamento ex art. 103.4 LJCA.

Hay un problema ajeno a lo que nos está ocupando pero próximo y que merece atención: puede que el interesado haya instado el incidente del art. 103.5 y que haya sido desestimado; podrá entonces interponer un contencioso autónomo aunque con invocación de vicios distintos a los del art. 103.4 LJCA (por eso digo que es un

cosas que se excluyen mutuamente". Cabe conciliar estas sentencias si se entiende que los dos cauces son compatibles cuando no se den los requisitos de la litispendencia y de la cosa juzgada (litispendencia si los dos cauces se simultanean y cosa juzgada si se suceden en el tiempo). Así, no serán acumulables si en ellos combate exactamente la misma actuación y por el mismo vicio del art. 103.4 LJCA; pero serán acumulables si no se dan esas identidades o las partes no son exactamente las mismas. Por tanto, tras fracasar en el incidente del art. 103.5 LJCA el perdedor podrá impugnar el mismo acto en un proceso autónomo pero en éste ya no le será posible argüir el vicio del art. 103.4 LJCA. A ese respecto, la resolución que resuelva el incidente del art. 103.5 LJCA tendrá para él efectos de cosa juzgada material en su vertiente excluyente. Supra epígrafe I.1.c).

127 SUAY RINCÓN, J. (2018: 46-47) que no obstante añade la posibilidad de que, si ya existía un proceso en curso, cabría añadir posteriormente como nuevo motivo impugnatorio la contradicción con la sentencia.

128 Esto, en principio, debería aplicarse también a los actos anteriores a la sentencia que, como hemos visto, pueden tener este vicio invalidante si la Administración los dictó temiéndose ya que le sería desfavorable. Y esto limita notablemente la posibilidad de su impugnación: antes de la sentencia (más exactamente, antes de su firmeza) no se podrá alegar el art. 103.4 LJCA; y después de ella habrán pasado normalmente los plazos de recurso. En realidad, el mismo problema se plantea si se trata de seguir la vía del art. 103.5 LJCA, como antes vimos; e, igual que propusimos allí, también para el recurso autónomo basado en el art. 103.4 LJCA cabría sostener que los plazos de dos meses deben contarse desde que la sentencia burlada haya devenido firme. 
problema ajeno a lo que propiamente nos ocupa). Pero cuando vaya a interponer ese recurso autónomo, si el interesado ha estado esperando a la resolución del incidente del art. 103.5, se le habrán pasado los plazos para el recurso autónomo. Por ello resulta aconsejable la interposición simultánea de ambas impugnaciones: la del art. 103.5 LJCA, constreñida al vicio del art. 103.4; y la del recurso autónomo en que se aleguen los demás vicios, no el del art. 103.4 LJCA ${ }^{129}$. Pero los tribunales, comprendiendo que tal cautela es excesiva, han inventado praeter legem la solución de conferir ex profeso un plazo ad hoc para interponer el recurso autónomo tras la desestimación del incidente del art. 103.5 LJCA $^{130}$.

\section{E) Competencia}

La competencia será del órgano judicial que corresponda de acuerdo con los arts. 8 a 14; o sea, no del competente para la ejecución conforme a los arts. 7.1 y 103.1 $\mathrm{LJCA}^{131}$.

\section{F) Legitimación}

Como un contencioso-administrativo ordinario que es, tendrá legitimación activa cualquier interesado: quien vea afectados sus derechos o intereses legítimos por el acto o reglamento que ahora ataca; y si hay acción popular, como en urbanismo, estará abierta para cualquiera. En consecuencia, es indiferente que el actor no hubiese sido parte y ni siquiera hubiera podido serlo en el proceso originario en el que se dictó la sentencia cuya vulneración se alega.

Será parte demandada la Administración autora de la actuación impugnada. Normalmente será la misma vencida en el proceso originario cuya sentencia se hace valer. Pero en tanto que, como hemos aceptado, cabe imaginar que otra Administración distinta produzca actos o reglamentos con la intención de burlar una sentencia

129 En la misma dirección FERNÁNDEZ RODRÍGUEZ, T.R. (2011: 146) aunque refiriéndose más bien a la superación de los plazos para interponer el recurso autónomo tras el fracaso en primera instancia de la vía del art. 103.5 LJCA.

130 Se observa, al menos, en los AATS de 21 de enero y de 6 de febrero de 2019 (recursos 504 y 508/2014; JUR/2019/35339 y JUR/2019/51782). Tras desestimar la acción de nulidad en ejecución de sentencia y remitir a un contencioso autónomo, añaden: "Se habilita para ello un plazo de dos meses a partir de la notificación del presente Auto para el caso de que no hubiere sido interpuesto ya dicho recurso". Aunque luego en la parte dispositiva se habla de un plazo de veinte días. BOCANEGRA SIERRA, R., "La anulación en incidente de ejecución de sentencias de decisiones administrativas que infringen lo ejecutoriado”, en GARCÍA DE ENTERRÍA, E. y ALONSO GARCÍA, R. (Coords.), Administración y justicia, Un análisis jurisprudencial. Liber amicorum Tomás-Ramón Fernández, Givitas, 2012, I, pp. 799-800, que pone de relieve este problema, da cuenta de un Auto de 29 de septiembre de 2006, que ya confirió un plazo de 30 días desde la notificación de la firmeza del mismo Auto.

131 Expresamente lo afirma la STS de 29 de septiembre de 2009 (casación 2827/2005; Ar. 325 de 2010). 
dictada en un proceso en la que no fue parte, hay que admitir que el proceso contencioso-administrativo autónomo basado en el art. 103.4 LJCA podrá dirigirse contra ella. Es más, en ese caso, como ya se ha dicho, el proceso autónomo, y no el del art. 103.5 LJCA, es cauce adecuado. Por supuesto que también tendrán legitimación pasiva aquellos sujetos a que se refiere el art. 21.1.b) LJCA.

\section{G) Motivos}

En este recurso autónomo se podrá invocar, junto al art. 103.4 LJCA, cualquier otra infracción del ordenamiento aunque nada tenga que ver con la anterior sentencia ${ }^{132}$. Y para que prospere aquella causa de nulidad deben darse los requisitos del art. 103.4 LJCA que antes se expusieron. Ahora bien, en este contexto es posible que la falta de alguno de sus requisitos, particularmente del subjetivo, aunque impida aplicar propiamente el art. 103.4, no sea obstáculo para apreciar la nulidad del nuevo acto o reglamento por su vulneración objetiva de la sentencia. Por ello resulta aconsejable que la invalidez del nuevo acto o reglamento por contradicción con la sentencia anterior se fundamente no sólo en el art. 103.4 LJCA sino también en la pura vulneración del derecho fundamental a la tutela judicial efectiva de acuerdo con el art. 47.1.a) LPAC.

\section{H) Objeto: actividad impugnable y pretensiones}

Con los límites ya aludidos, es actividad administrativa impugnable cualquiera que puede estar aquejada de la nulidad del art. 103.4 LJCA. Y desde luego es posible que se impugne un acto con base en la nulidad ex art. 103.4 del reglamento que aplica: si antes, incluso para el incidente del art. 103.5 LJCA, admitimos el recurso indirecto contra reglamentos, con más razón hay que admitirlo en el proceso autónomo: se tratará de un normal recurso contencioso indirecto contra reglamentos con la única singularidad de que el vicio es el del art. 103.4 LJCA. Y cabrá que ese recurso indirecto conduzca, no sólo a la declaración de nulidad del acto, sino también a la del reglamento cuando el juez o tribunal sea competente para ello o, en otro caso, al resolverse la cuestión de ilegalidad.

132 Así, en un caso en que se había vuelto a aprobar un Plan Parcial, tras la anulación de otro anterior, y en el que el nuevo se había impugnado en contencioso autónomo, dice la STS de 8 de febrero de 2013 (casación 2134/2012; Ar. 1382) que hay dos vías: la de la impugnación en ejecución de la sentencia anterior (la del art. 103.5 LJCA) y la ordinaria; la primera limitada a comprobar si se ha incumplido la sentencia, pero no la segunda: "En el segundo caso, por el contrario, los contornos son menos angostos, pues se puede alegar cualquier infracción normativa que ponga de manifiesto que dicho acto o disposición vulnera el ordenamiento jurídico. En el bien entendido de que, entre tales vicios de legalidad, se comprenden también aquellos que tienen por objeto poner de relieve que la nueva actuación o regulación vulnera lo declarado en una sentencia firme”. Como en el incidente del art. 103.5 no cabe analizar más vicio que el del art. 103.4, dice la STS de 6 de abril de 2011 (casación 1602/2007; Ar. 2962) que la vía del contencioso autónomo será "la vía a seguir en el supuesto de que, junto a esta particular acción de tintes subjetivos (la del art. 103.4), se articulara otra basada en la nulidad material del nuevo acto o planeamiento". 
Junto con la anulación del acto o reglamento, se podrá pedir el restablecimiento de la situación jurídica lesionada y la condena de la Administración a hacer o dar algo, incluida la indemnización de daños y perjuicios. Esto, que cabe en todo contencioso-administrativo [arts. 31.2 y 71.1.b) LJCA], también será posible en éste que, a fin de cuentas, es un contencioso más con la modesta particularidad de invocar como motivo, único o junto con otros, el art. 103.4 LJCA.

\section{Contencioso-administrativo especial de protección de los derechos fundamentales}

En tanto que se entiende que el incumplimiento de las sentencias es contrario al derecho a su ejecución y que éste forma parte del derecho a la tutela judicial efectiva (art. $24 \mathrm{CE}$ ), es posible que la nulidad del art. 103.4 LJCA se canalice a través de un recurso especial de protección de los derechos fundamentales ${ }^{133}$.

\section{Recursos administrativos}

Los recursos administrativos ordinarios se pueden fundar en cualquier causa de nulidad o anulabilidad, como aclara el art. 112.1.1 ${ }^{\circ}$ in fine LPAG. Y no hay ninguna razón para excluir la del art. 103.4 LJCA. Por tanto, los recursos administrativos ordinarios de reposición y de alzada son cauce adecuado para ejercer una pretensión de nulidad basada precisamente en el art. 103.4 LJCA, sin perjuicio, desde luego, de que en el mismo recurso quepa invocar simultáneamente otros vicios invalidantes. Ello, claro está, salvo que el vicio del art. 103.4 LJCA se impute a reglamentos, puesto que contra estos no caben recursos administrativos (art. 112.3 LPAC). En su caso, los recursos administrativos especiales (previstos únicamente para ciertos actos pero sin limitación de motivos) también pueden albergar una pretensión anulatoria basada en el art. 103.4 $\mathrm{LJCA}^{134}$.

Uniendo lo que se acaba de decir con algunas ideas anteriores, debe aclararse lo siguiente:

a) No sólo es que sea posible interponer un recurso de alzada fundado en el art. 103.4 LJCA sino que, si se trata de un acto dictado en el ejercicio de las potestades

133 Lo afirma XIOL RÍOS, J. A. (2016: 724). Ahora bien, es dudoso si esta posibilidad hay que entenderla con los mismos límites que hemos afirmado para el contencioso-administrativo autónomo ordinario de modo que sólo quepa para las actuaciones de la Administración producidas en ejercicio de las normales potestades administrativas, no para las que se presenten como cumplimiento de la sentencia, que habrían de combatirse ante el juez de la ejecución y por la vía del art. 103.5 LJCA. En principio, me parece más adecuado no excluir la posibilidad de este proceso en ningún caso.

134 Es el caso de los recurso económico-administrativos que, como se ve en dos SSTS de 26 de febrero de 2015 (casaciones 555 y 754/2014; Ar. 2082 y 1781), se plantearon en los casos enjuiciados "por cautela" al mismo tiempo que un incidente del art. 103.5 LJCA. 
ordinarias de la Administración y que no agote la vía administrativa, el recurso de alzada será necesario como paso previo al recurso contencioso-administrativo autónomo $^{135}$;

b) Los recursos administrativos no serán obligatorios para ejercer la acción de nulidad por el cauce del art. 103.5 LJCA, pero incluso en tal hipótesis son posibles ${ }^{136}$; y

c) Lo anterior vale en particular para los supuestos en los que lo que se combata sea uno de esos actos dictados por la Administración para el cumplimiento de la sentencia previa: en tal hipótesis no cabe el contencioso-administrativo autónomo sino sólo el incidente en ejecución de sentencia, como hemos visto; pero antes de suscitar ese incidente caben potestativamente los recursos administrativos ordinarios ${ }^{137}$.

\section{Revisión de oficio}

La revisión de oficio del art. 106 LPAC puede basarse en la causa de nulidad del art. 103.4 LJCA $^{138}$. Nada se opone a ello y, al contrario, si precisamente el art. 103.4 LJCA ha optado por el grado máximo de invalidez -la nulidad de pleno derecho- eso tiene la consecuencia directa de abrir esa vía ${ }^{139}$. La podrá emprender motu proprio la Administración. Pero también podrá ser instada por cualquier interesado en el caso de actos, no de reglamentos (art. 106.2 LPAC a contrario). Si las vías antes expuestas son procedentes contra actos no firmes, esta otra es adecuada frente a los que han alcanzado firmeza. Tras el ejercicio de la acción de nulidad del art. 106.1 LPAC, el particular tendrá acceso a la jurisdicción contencioso-administrativa para recurrir la resolución desestimatoria (o el silencio negativo) de su solicitud de revisión de oficio.

135 Supra, epígrafe IV.1.c).

136 Supra, epígrafe III.3.

137 Pensemos en una sentencia que anuló una autorización y que condenó restablecer la realidad física alterada en su virtud; y en un acto posterior de la Administración que, en cumplimiento de esa sentencia, ordena una demolición parcial. Quien crea, por ejemplo, que lo que procede es una demolición total podrá combatir esa orden, desde luego, por el cauce del art. 103.5 LJCA (no en recurso contenciosoadministrativo autónomo). Pero no veo inconveniente en que antes interponga un recurso administrativo basado precisamente en el art. 103.4 LJCA. Esto no hurta al juez de la ejecución lo que le corresponde: seguirá siendo el que a la postre decidirá si se ha ejecutado o no, bien o mal, la sentencia; sólo que lo hará tras una reconsideración de la Administración que igualmente someterá a su escrutinio desde ese punto de vista.

138 Así lo admite ORTEGA ÁLVAREZ, L. (2001: 507).

139 Aparentemente en contra BAÑO LEÓN, J. M. (2016: 96), niega la posibilidad de revisión de oficio "pues eso supondría tanto como permitir que la Administración revocara la sentencia”. Obviamente eso es inadmisible. Pero sí cabe la revisión de oficio precisamente para declarar la nulidad conforme al art. 103.4 LJCA, esto es, para ajustarse a la sentencia. 


\section{Incidentes de ejecución con otras pretensiones}

También puede esgrimirse el art. 103.4 LJCA como base de otras pretensiones ejecutivas. Así, en primer lugar, pueden instarse medidas de ejecución forzosa de una sentencia en virtud del art. 104.2 LJCA y, si hay algún acto o reglamento que pueda impedirlas, alegar su nulidad ex art. 103.4 LJCA para, pese a todo, conseguir aquellas medidas. Y asimismo, en segundo lugar, el art. 103.4 puede servir de fundamento para oponerse a la pretensión de que se declare la imposibilidad de ejecución de la sentencia ejercida por la vía del art. 105.2 $\mathrm{LJCA}^{140}$; esto es, como medio de defensa, como excepción procesal frente a la Administración que precisamente enarbola el acto o reglamento para pedir la inejecución ${ }^{141}$. Para los dos casos apuntados son de interés las siguientes observaciones:

- No debe declararse formalmente la nulidad del acto o reglamento ${ }^{142}$. Ni es eso lo que se pide ni es eso lo que hay que resolver. Tal nulidad se apreciará en la fundamentación jurídica de la resolución judicial pero lo que debe resolver es sólo, en el primer caso, las medida ejecutivas pertinentes o, en el segundo, que no se da

140 Es un supuesto frecuente, como nota CHINCHILLA PEINADO, J. A. (2008: 75).

141 Lo afirma, entre las más recientes, la STS 113/2019, de 4 de febrero (casación 3965/2017; Ar. 354): "la causa de nulidad establecida en el art. 103.4 LJCA (...) determina la total ineficacia (...) a los efectos pretendidos de inejecución" de forma que procede un "pronunciamiento judicial desestimando la alegación de imposibilidad de ejecución formulada al amparo del art. 105.2 LJCA".

El interesado podrá alegar contra la petición de imposibilidad de ejecución de una sentencia que el reglamento o acto invocado por la Administración es inválido por el vicio del art. 103.4 LJCA y por cualquier otro más. Lo ejemplifica la STS de 4 de febrero de 2004 (casación 1479/2002; Ar. 828). La Administración pidió la declaración de imposibilidad de ejecución de la sentencia que anuló una licencia por la existencia de un nuevo acto administrativo (convalidación de licencia); frente a ello se alegó que el nuevo acto era inválido por "falta de la necesaria intervención previa de los organismos autonómicos competentes" y por el art. 103.4 LJCA. Esta STS apreció el primer vicio y anuló: "A partir de ahí es claro que la Sala de instancia no podía conceptuar la nueva licencia municipal como causa de imposibilidad legal de ejecutar la sentencia, pues tal carácter, fuerza o valor no puede predicarse de aquello que no es conforme con el ordenamiento jurídico". Y añade: "Lo que resta por examinar es ya escasamente trascendente, pues apreciado correctamente que no concurre una causa de imposibilidad legal de ejecutar la sentencia, poco importa que la nueva licencia merezca o no la sanción de nulidad de pleno derecho que predica el art. 103.4 LJCA".

142 Así, por ejemplo, STS de 10 de diciembre de 2003, casación 2550/2001, Ar. 107 de 2004. Pero en ocasiones se admite que esa nulidad alegada como medio de defensa se declare formalmente en el fallo si el tribunal tiene competencia para ello. Así se ve ya en la STS de 5 de abril de 2001 (casación 3655/1996; Ar. 3030); en la STS de 10 de mayo de 2007 (casación 3786/2004, Ar. 8062); y, aunque confusamente, en la STS 113/2019, de 4 de febrero (casación 3965/2017; Ar. 354). Mantengo por el contrario que esa nulidad simplemente apreciada para desestimar la pretensión principal no debe declararse en el fallo pues nadie ha ejercido tal pretensión. No es un problema de competencia y por eso, aunque el tribunal que esté actuando tenga la competencia para declarar la nulidad si se le pidiera, tampoco deberá declararla. 
causa de imposibilidad de la ejecución. Por eso mismo, suponiendo que lo nulo sea un reglamento, no debe suscitarse una cuestión de ilegalidad ${ }^{143}$.

- Procede la apreciación de la nulidad del art. 103.4 LJCA aunque nadie la haya pedido antes (realmente tampoco la pide ahora) ni se haya declarado; y, lo que es importante, aunque hayan pasado los dos meses para impugnar el reglamento o acto de que se trate ${ }^{144}$.

- En este entorno la nulidad por la causa del art. 103.4 LJCA podrá ser apreciada por el juez o tribunal que esté conociendo de la pretensión aunque carezca de competencia para declarar formalmente aquella nulidad ${ }^{145}$; incluso podrá apreciarla de oficio ${ }^{146}$.

143 No debe hacerse porque aquí no se parte de un recurso indirecto contra el reglamento nulo por el art. 103.4 LJCA (que es presupuesto necesario según la LJCA para que proceda después la cuestión de ilegalidad) sino simplemente la alegación de nulidad como base de una pretensión distinta o como medio de defensa. Véase REBOLLO PUIG, M., (1999: 38-39) y CARLÓN RUIZ, M., La cuestión de ilegalidad en el contencioso-administrativo contra reglamentos, Civitas, $2^{\mathrm{a}}$ ed., 2005, p. 141. Es explícito GARCÍA DE LA ROSA, C., "La problemática de la ejecución de las sentencias urbanísticas: especial referencia a las modificaciones introducidas en la Ley de la Jurisdicción Contencioso-Administrativa en relación con la demolición de construcciones ilegales", Revista General de Derecho Administrativo, no 45 (2017). Tras aceptar que un Juzgado, en ejecución de la sentencia dictada por él, inaplique el reglamento o plan dictado para burlar su sentencia, se plantea si después debería o podría suscitar cuestión de ilegalidad para que se anulase tal reglamento. Su respuesta es negativa: “... el juzgado se limitará a inaplicar la disposición (pues) no existe norma alguna que le imponga en ese caso la promoción de un proceso declarativo a fin de conseguir (...) la expulsión de la norma...".

144 En el caso de los reglamentos ello no ofrece dudas a la vista del art. 6 LOPJ. Y la misma solución procede ante actos: no importará que el acto haya devenido firme; la firmeza impide los recursos ordinarios pero no esta apreciación de su nulidad como sustento de otra pretensión o de una excepción defensiva que, por ser de pleno derecho, es imprescriptible y opera ipso iure, es decir, sin necesidad de declaración formal previa. Vid. REBOLLO PUIG, M., "La nulidad en Derecho Administrativo", fusticia Administrativa, n" 44 (2009), pp. 23 y 25. Y a esto no se opone la presunción de validez de los actos administrativos que nunca tiene eficacia frente a los jueces y tribunales.

145 Ya lo postuló BAÑO LEÓN, J. M. “Artículo 103.4 y 5”, REDA, núm. 100 (1998), pp. 723 a 725. Véase también HUERGO LORA, A. (2001: 303-305). Y la jurisprudencia lo acepta como demuestra, por todas, la STS 113/2019, de 4 de febrero (casación 3965/2017; Ar. 354): “... la falta de competencia para declarar la nulidad de pleno derecho de tales actos o disposiciones no desapodera al órgano jurisdiccional para ejercer el correspondiente control en la ejecución de la sentencia, que tiene atribuido por ley, y en tal sentido valorar si los actos y disposiciones que se invocan como justificación para alegar el incumplimiento de la sentencia en sus propios términos, incurren en la causa de nulidad establecida, que en caso afirmativo determina la total ineficacia de los mismos a los efectos pretendidos en ejecución y, en consecuencia, el correspondiente pronunciamiento judicial desestimando la alegación de imposibilidad formulada al amparo del art. 105.2 LJCA". En parte, esto es aplicación del principio según el cual el juez de la acción es juez de la excepción; esto es, el juez que conoce de una pretensión principal puede decidir sobre todos los medios de defensa, aunque si hubieran sido propuestos a título principal escaparían de su competencia.

146 Es lo que doctrina clásica predica de los vicios de nulidad de pleno derecho, como es el del art. 103.4 LJCA. Pero antes deberá someterla a las partes de acuerdo con los arts. 33.2 y 65.2 LJCA. 
- Esta apreciación de la nulidad ex art. 103.4 LJCA vale tanto para actos dictados justamente para ejecutar la sentencia como para los producidos, al margen de ello, en ejercicio de las potestades ordinarias de la Administración.

Justamente el hecho de que esta vía sea transitable frente a todo tipo de actos, incluso firmes, y hasta cuando el juez sea incompetente para declarar la nulidad del reglamento o acto en cuestión es lo que le da gran relevancia y utilidad pues permite paliar en ejecución todos los límites del art. 103.5 LJCA, incluso el competencial de su último inciso.

\section{No cabe esta causa de nulidad como sustento del incidente del art. 108.2 LJCA}

Los primeros comentaristas de la LJCA sostuvieron que en el incidente del art. 108.2 LJCA cabía, entre otras cosas, alegar y declarar la nulidad prevista en el art. 103.4 $\mathrm{LJCA}^{147}$ e incluso la de cualquier acto contrario a la sentencia sin necesidad de finalidad elusiva ya que este precepto no exige animus. Pero la jurisprudencia lo ha descartado: si el art. 103.5 LJCA sirve para el caso de actuaciones administrativas jurídicas, este art. 108.2 sólo vale contra actuaciones materiales contrarias a lo falla$\mathrm{do}^{148}$. Por eso no prevé ninguna declaración de nulidad: porque se supone que no hay ningún acto contrario a la sentencia sino sólo actuaciones materiales de las que es por completo inadecuado predicar su invalidez; sólo tiene sentido hablar de su ilegalidad, del deber de cesar en ellas y de reponer la realidad alterada. Ahora bien, si la actuación material combatida tiene sustento en algún acto de la Administración, entonces

147 BAÑo LEÓN, J. M. (1998:723) Y GÓMEZ PUENTE, M., “Art. 108”, REDA, nº 100) (1998), p. 774).

148 La STS de 31 de enero de 2006 (casación 8263/2003; Ar. 4356) refleja esta dualidad: “... pueden deducirse dos supuestos diferentes de ejecución fraudulenta, el primero (103.4 y 5 LJCA), con una connotación estrictamente jurídica, y, el segundo (108.2 LJCA), que pudiera tener como fundamento una actuación de tipo material: $1^{\circ}$ ) Para evitar, justamente, este tipo de actuaciones, el artículo 103 en sus números 4 y 5, contempla la situación, dibujada por el legislador, de los supuestos «de los actos y disposiciones contrarios a los pronunciamientos de las sentencias, que se dicten con la finalidad de eludir su cumplimiento» (...) $2^{\circ}$ ) El segundo supuesto (108.2 LJCA) (...) viene determinado no como consecuencia de una actividad jurídica de la Administración - esto es mediante actos o disposiciones dictados para contradecir los pronunciamientos de las sentencias, que acabamos de examinar- sino como consecuencia de una actividad material de la propia Administración «que contraviniere los pronunciamientos del fallo» de la misma. Es, como decimos, el supuesto contemplado en el artículo 108.2 LJCA...". Igualmente, entre otras, SSTS de 26 de diciembre de 2006 (casación 385/2004, Ar. 4582 de 2007), 10 de mayo de 2007 (casación 3786/2004, Ar. 8062), 12 de diciembre de 2014 (casación 2847/2012; Ar. 6823), 1280/2017 de 18 julio (casación núm. 1264/2016; Ar. 3967) y 1646/2017, de 31 de octubre (casación 1677/2016; Ar. 4812). 
lo pertinente será combatir éste por cualquiera de las vías expuestas (la del art. 103.5 LJCA o las alternativas analizadas), no la del art. 108.2 LJCA $^{149}$.

149 Lo explica XIOL RÍOS, J. A. (2016: 723). Parte de que ante actuaciones materiales no procede aplicar el art. 103.4 LJCA. Pero matiza: "Sin embargo, incluso la vía de hecho de la Administración puede hacer necesaria la declaración de nulidad de pleno derecho, pues basta un acto fisicamente posible avalado por una voluntad de ejecución para que (...) pueda ser necesaria una resolución judicial dejándolo sin efecto". 


\section{BIBLIOGRAFÍA}

AGOUÉS MENDIZÁBAL, C., "La modulación de los efectos de la invalidez de los reglamentos", en El alcance de la invalidez de la actuación administrativa: Actas del XII Congreso de la Asociación Española de Profesores de Derecho Administrativo, INAP, Madrid, 2017.

BAÑO LEÓN, J. M. "Artículo 103.4 y 5”, Revista Española de Derecho Administrativo, núm. 100, monográfico de Comentarios a la Ley de la Jurisdicción Contencioso-Administrativa de 1998 (1998). "La eficacia de las sentencias contra la Administración o la claudicación del Estado de Derecho", Revista Española de Derecho Administrativo, núm. 177 (2016).

BASSOLS COMA, M. "La asimilación de los planes de urbanismo a normas reglamentarias y problemática jurídica de su anulación judicial”, en G. SORIA MARTÍNEZ y M. BASSOLS COMA (Coords.), Los efectos de la nulidad de los instrumentos de planeamiento urbanístico, Aranzadi, 2017,

BOCANEGRA SIERRA, R., "La anulación en incidente de ejecución de sentencias de decisiones administrativas que infringen lo ejecutoriado", en GARCÍA DE ENTERRÍA, E. y ALONSO GARCÍA, R. (Coords.), Administración y justicia, Un análisis jurisprudencial. Liber amicorum Tomás-Ramón Fernández, Civitas, 2012, vol. I,

BUENO ARMIJO, A., "La revisión de oficio", en GOSÁLBEZ PEQUEÑO, H. (Dir.), La nueva Ley del Procedimiento Administrativo Común, Wolters Kluwer, 2016.

CALVO ROJAS, E., "Los planes urbanísticos como disposiciones de carácter general. Problemas que suscita la declaración de nulidad de los instrumentos de planeamiento. Suspensión cautelar de la efectividad de los planes impugnados en vía jurisdiccional”, en GARCÍA ENTERRÍA, E., y ALONSO GARCÍA, R., (Coords.), Administración y justicia. Un análisis jurisprudencial: liber amicorum Tomás-Ramón Fernández, Civitas, 2012, vol. I.

CANO CAMPOS, T., La invalidez sobrevenida de los actos administrativos, Civitas, 2004.

CARBONELL PORRAS, E., "La pérdida sobrevenida de legitimación. Revisión de la doctrina de la perpetuatio legitimationis (a propósito de la sentencia de la Sala de lo Contencioso-administrativo del Tribunal Supremo de 30 de mayo de 2011)", en GARCíA DE ENTERRÍA, E. y ALONSO GARCÍA, R. (Dirs.), $A d-$ ministración y justicia, Un análisis jurisprudencial. Liber amicorum Tomás-Ramón Fernández, Civitas, 2012, vol. I; publicado también en Revista Española de Derecho Administrativo, núm. 153 (2012). 
GARLÓN RUIZ, M., La cuestión de ilegalidad en el contencioso-administrativo contra reglamentos, Civitas, $2^{\mathrm{a}}$ ed., 2005.

CLAVERO ARÉVALO, M. "Actuaciones administrativas contrarias a los pronunciamientos de las sentencias", en La justicia administrativa. Libro homenaje al Prof. Dr. D. Rafael Entrena Cuesta, Atelier, Barcelona, 2003.

CASTILLO BLANCO, F., "La ejecución propia e impropia de sentencias en el ámbito contencioso-administrativo", Revista Andaluza de Administración Pública, núm. 100 (2018).

GHINGHILlA PEINADO, J. A. "La ejecución aparente del fallo de las sentencias contencioso-administrativas en el ámbito urbanístico. Un balance tras 10 años de vigencia de la Ley 29/1998”, Revista de Derecho Urbanistico y Medioambiente, núm. 245 (2008).

EZQUERRA HUERVA, A. "La ejecución de sentencias", en EZQUERRA HUERVA, A. y OLIVÁN DEL CACHO, J. (Dirs.), Estudio de la Ley de la furisdicción Contencioso-Administrativa, Tirant lo Blanch, 2014. "La ejecución de sentencias contencioso-administrativas y adopción de medidas cautelares. En particular, la suspensión de la ejecución de sentencias por el tribunal de instancia en caso de interposición de recurso de amparo", Revista de Administración Pública, núm. 197 (2015).

FERNÁNDEZ HERNANDO, J. "El incumplimiento de la sentencia administrativa, sus formas y su tratamiento jurisprudencial", en Libro homenaje al profesor Fordana de Pozas, Instituto de Estudios Políticos, Madrid, 1961, III. Vol. 1.

FERNÁNDEZ, T. R., "Algunas reflexiones sobre las formas indirectas de incumplimiento por la Administración de las sentencias de los tribunales de la jurisdicción contencioso-administrativa", Revista de Administración Pública, núm. 73 (1974).

- "El artículo 130.4 LJ no les gusta a los jueces", en SÁNCHEZ BLANCO, A., DOMÍNGUEZ BERRUETA DE JUAN, M. A., y RIVERO YSERN, J. L. (Coords.), El nuevo Derecho Administrativo. Libro homenaje al Profesor Dr. Enrique Rivero Ysern, Ratio Legis y Universidad de Salamanca, Salamanca, 2011.

FERNÁNDEZ FARRERES, G., "Las nuevas facultades del Tribunal Constitucional para asegurar el cumplimiento de sus resoluciones", Revista Española de Derecho Constitucional, núm. 112 (2018).

FONT i LLOVET, T., La ejecución de las sentencias contencioso-administrativas. Aspectos constitucionales, Civitas, Madrid, 1985. 
- "Medidas para hacer efectiva la ejecución de las sentencias", en MARTÍN-RETORTILLO BAQUER, L. (Coord.), La protección jurídica del ciudadano. Estudios en homenaje al Profesor Jesús González Pérez, Civitas, Madrid, 1993.

- "Justicia administrativa y ejecución de sentencias", en MONTORO CHINER, M. J. (Coord.), La justicia administrativa. Libro homenaje al Prof. Dr. D. Rafael Entrena Cuesta, Atelier, Barcelona, 2003.

GALÁN GALÁN, A., "Los poderes del juez en la ejecución de las sentencias: reacción frente a actos de la Administración o del legislador que tengan como fin eludir su cumplimiento", en SÁNCHEZ LAMELA, A., La ejecución de las sentencias contencioso-administrativas, Aranzadi, Cizur Menor, 2006.

GARCÍA DE LA ROSA, C., "La problemática de la ejecución de las sentencias urbanísticas: especial referencia a las modificaciones introducidas en la Ley de la Jurisdicción Contencioso-Administrativa en relación con la demolición de construcciones ilegales", Revista General de Derecho Administrativo, núm. 45 (2017).

GARCÍA LUENGO, J., "Los supuestos de nulidad de pleno derecho establecidos al margen de la Ley de Procedimiento Común", Revista de Administración Pública, núm. 159 (2002).

GEIS i CARRERAS, G., La ejecución de las sentencias urbanísticas, Atelier, Barcelona, $2^{\text {a }}$ ed., 2013.

GIFREU FONT, J., "La reconsideración de la naturaleza normativa de los instrumentos de planeamiento: ¿una panacea para modular el alcance y efectos del dogma de la nulidad absoluta de los reglamentos ilegales?", en AGUDO GONZÁLEZ, J. (Goord.), Nulidad del planeamiento y ejecución de sentencias, Bosch, Barcelona, 2018, pp. 38-39.

GIMENO SENDRA, V., Comentarios a la nueva Ley de la furisdicción Contencioso-Administrativa, Centro de Estudios Ramón Areces, Madrid, 1999.

GÓMEZ-FERRER RINCÓN, R., La imposibilidad de ejecución de sentencias en el proceso contencioso-administrativo, Civitas, Cizur Menor, 2008.

GONZÁLEZ PÉREZ, J., Comentarios a la Ley de la Ley de la furisdicción Contencioso-Administrativa, Civitas, Cizur Menor, $8^{a}$ ed., 2016. En algunas citas se ha utilizado la $3^{\text {a }}$ ed., 1998, por ser anterior a la actual LJCA.

GÓMEZ PUENTE, M., "Artículo 108", Revista Española de Derecho Administrativo, núm. 100, monográfico de Comentarios a la Ley de la Jurisdicción Contencioso-Administrativa de 1998 (1998) 
GONZÁLEZ SANFIEL, A. M., "Límites a la declaración de nulidad de los planes", en F. LÓPEZ RAMÓN y F. VILLAR ROJAS (Coords.), El alcance de la invalidez de la actuación administrativa, AEPDA/INAP, 2017.

HUERGO LORA, A., La resolución extrajudicial de conflictos en Derecho Administrativo, Publicaciones del Real Colegio de España, Bolonia, 2000.

- "La permanencia de un viejo problema: la reiteración de los actos administrativos anulados como forma de incumplimiento indirecto de las sentencias, con especial referencia a los efectos de los recursos de casación en interés de Ley", Revista de Administración Pública, núm. 156 (2001).

HUERTA GARICANO, I., "La ejecución de sentencias en la Ley 29/1998, de la Jurisdicción Contencioso-Administrativa, Cuadernos de Derecho Fudicial, núm. 2 (2000).

LOZANO CUTANDA, B. "Convalidaciones legislativas de reglamentos anulados: dos pronunciamientos contradictorios del Tribunal Constitucional (SSTC 50/2015 y 231/2015)", Diario la Ley, núm. 8720 (2016).

MAGALDI, N., "La extensión de los efectos de las sentencias", en EZQUERRA HUERVA, A. y OLIVÁN DEL CACHO, J. (Dirs.), Estudio de la Ley de la furisdicción Contencioso-Administrativa, Tirant lo Blanch, 2014.

MORILLO-VELARDE PÉREZ, J. I., "La ejecución de sentencias en el proceso contencioso administrativo", Revista del Poder Fudicial, núm. 55 (1999).

ORTEGA ÁLVAREZ, L., "La ejecución de sentencias", en LEGUINA VILLA, J. y SÁNCHEZ MORÓN, M. (Dirs.), Comentario a la Ley de la furisdicción Contencioso-Administrativa, Lex Nova, Valladolid, $2^{\text {a }}$ ed., 2001.

- "La ejecución de sentencias", fusticia Administrativa, núm. extraordinario dedicado a la Ley de la Jurisdicción Contencioso-Administrativa (1999)

PÉREZ ANDRÉS, A. A., Los efectos de las sentencias de la Furisdicción Contencioso-Administrativa, Aranzadi, Cizur Menor, 2000.

PÉREZ MORENO, A., "La conciliación judicial”, fusticia Administrativa, núm. extraordinario dedicado a la Ley de la Jurisdicción Contencioso-Administrativa (1999),

REBOLLO PUIG, M., “Artículos 72 y 73”, Revista Española de Derecho Administrativo, núm. 100, monográfico de Comentarios a la Ley de la Jurisdicción Contencioso-Administrativa de 1998 (1998). 
- "Recursos contra reglamentos y cuestión de ilegalidad", Justicia Administrativa, núm. extraordinario dedicado a la Ley de la Jurisdicción Contencioso-Administrativa (1999).

- "La nulidad en Derecho Administrativo", Justicia Administrativa, núm. 44 (2009).

RUIZ BURSÓN, F. J., "Las innovaciones en el planeamiento urbanístico como causa de imposibilidad legal para la ejecución de sentencias", Revista General de Derecho Administrativo, núm. 33 (2013).

SANTAMARÍA PASTOR, J. A., La Ley Reguladora de la Furisdicción Contencioso-Administrativa, Iustel, 2010.

- "Muerte y transfiguración de la desviación de poder: sobre las sentencias anulatorias de los planes", Revista de Administración Pública, núm. 195 (2014).

- "Una imprevista disfunción del sistema urbanístico: la mortalidad judicial de los planes", Práctica Urbanística, núm. 141 (2016).

SESMA SÁNCHEZ, B., La nulidad de las liquidaciones tributarias, Aranzadi, Cizur Menor, 2017.

SORO MATEO, B., "Sobre el alcance de la anulación de los planes urbanísticos por defectos de forma. La anulación de la Revisión del PGOU de Cartagena", Revista de Derecho Urbanístico y Medio Ambiente, núm. 315 (2017).

SUAY RINCÓN, J., "La caracterización jurídica de la potestad de revisión de oficio", en SORIANO GARCÍA, J. E. (Dir.), Por el Derecho y la libertad. Libro homenaje al Profesor Fuan Alfonso Santamaría Pastor, Iustel, Madrid, 2014, II.

- "La «afectación» de la anulación de los Planes de Urbanismo a sus actos de ejecución: la perspectiva de la Ley Jurisdiccional", Revista de Derecho Urbanístico y Medio Ambiente, núm. 324 (2018).

TOLOSA TRIBIÑO, G., "El incidente de ejecución de sentencias: aspectos procesales", en SÁNCHEZ LAMELA, A. (Coord.), La ejecución de sentencias contencioso-administrativas, Aranzadi, Cizur Menor, 2006.

TORNOS MAS, J., “Artículo 103.1, 2 y 3”, Revista Española de Derecho Administrativo, núm. 100 (1998).

XIOL RÍOS, J. A., "Artículo 103”, en ESPÍN TEMPLADO, E. (Coord.), Comentarios a la Ley Reguladora de la Jurisdicción Contencioso-Administrativa, Tirant lo Blanch, Valencia, 2016. 